Manganese-Oxide Minerals in Fractures of the Crater Flat Tuff in Drill Core USW G-4, Yucca Mountain, Nevada

B. Arney Carlos

D. L. Bish

S. J. Chipera 
MANGANESE-OXIDE MINERALS IN FRACTURES OF THE CRATER FLAT TUFF IN DRILL CORE USW G-4, YUCCA MOUNTAIN, NEVADA

by

B. Arney Carlos, D. L. Bish, and S. J. Chipera

\begin{abstract}
The Crater Flat Tuff is almost entirely below the water table in drill hole USW G-4 at Yucca Mountain, Nevada. Manganese-oxide minerals from the Crater Flat Tuff in USW G-4 were studied using optical, scanning electron microscopic, electron microprobe, and $\mathrm{x}$-ray powder diffraction methods to determine their distribution, mineralogy, and chemistry. Manganese-oxide minerals coat fractures in all three members of the Crater Flat Tuff (Prow Pass, Bullfrog, and Tram), but they are most abundant in fractures in the densely welded devitrified intervals of these members. The coatings are mostly of the cryptomelane/hollandite mineral group, but the chemistry of these coatings varies considerably. Some of the chemical variations, particularly the presence of calcium, sodium, and strontium, can be explained by admixture with todorokite, seen in some X-ray powder diffraction patterns. Other chemical variations, particularly between $\mathrm{Ba}$ and $\mathrm{Pb}$, demonstrate that considerable substitution of $\mathrm{Pb}$ for $\mathrm{Ba}$ occurs in hollandite. Manganese-oxide coatings are common in the $10-\mathrm{m}$ interval that produced $75 \%$ of the water pumped from USW G-4 in a flow survey in 1983. Their presence in waterproducing zones suggests that manganese oxides may exert a significant chemical effect on groundwater beneath Yucca Mountain. In particular, the ability of the manganese oxides found at Yucca Mountain to be easily reduced suggests that they may affect the redox conditions of the groundwater and may oxidize dissolved or suspended species. Although the Mn oxides at Yucca Mountain have low cation exchange capacities, these minerals may retard the migration of some radionuclides, particularly the actinides, through scavenging and coprecipitation.
\end{abstract}




\section{i. IVIRODUCTION}

Yucca Mountain, located on the southwest margin of the Nevada Test Site (Fig. 1), is being studied as a potential repository for high-level nuclear waste. These studies are coordinated under the Yucca Mountain Project (YMP) managed by the Nevada Operations Office of the U.S. Department of Energy. Several holes have been drilled at Yucca Mountain for geologic and hydrologic studies. Drill hole USW G-4, the most recent (1982) cored hole within the proposed repository block, was continuously cored from $22 \mathrm{ft}$ to $3001 \mathrm{ft}$ total depth (TD). The drilling history, core lithology, and geophysical logs of the well are given in Spengler and Chornack (1984). A preliminary study of frequency and orientation of fractures in the core is included in Spengler and Chornack (1984); a more detailed analysis is being performed by the U.S. Geological Survey with the help of geologists from Fenix and Scisson.

No attempt has been made in this study to quantify the relative abundances of different fracture types. Stratigraphic descriptions used in this report are from Spengler and Chornack (1984). A general stratigraphy of the Crater Flat Tuff in USW G-4 based on Spengler and Chornack (1984) is shown in Fig. 2. All the samples from the Crater Flat Tuff are indicated, and the distributions of manganese-oxide coatings and other fracture coatings are shown.

The study of fracture-lining minerals is important both in the characterization of mineralogy and chemistry along potential transport pathways between the repository and the accessible environment and in understanding the role of fractures and faults as past transport pathways. Drill hole USW G-4 was chosen for detailed study of fracture-lining minerals because it is closest to the planned YMP exploratory shaft. Previous reports on fracture-lining minerals in USW G-4 include Carlos (1985) on the unsaturated zone and Carlos (1987) on the saturated zone. Carlos (1987) included photographs and some discussion of the manganese oxide minerals in the Crater Flat Tuff. Some of the manganese oxides seen at Yucca Mountain, particularly the tunnelstructure minerals (e.g., cryptomelane, hollandite, coronadite, and todorokite) and the layerstructure mineral lithiophorite, are important for several reasons. These materials consist predominantly of fully-oxidized $\mathrm{Mn}$ in the +4 state with minor $\mathrm{Mn}^{+3}$ (Table l) (Manceau and Combes, 1988; Manceau, written communication, 1988; Post and Bish, 1988), and they have structures with tunnels (layers in lithiophorite) containing exchangeable cations such as $\mathrm{Ba}, \mathrm{Ca}$, $\mathrm{Pb}, \mathrm{K}$, and $\mathrm{Na}$. Bish and Post (1989) showed that these tunnel-structure minerals are very easily reduced, suggesting that they may form important redox couples with other oxidizable species, 


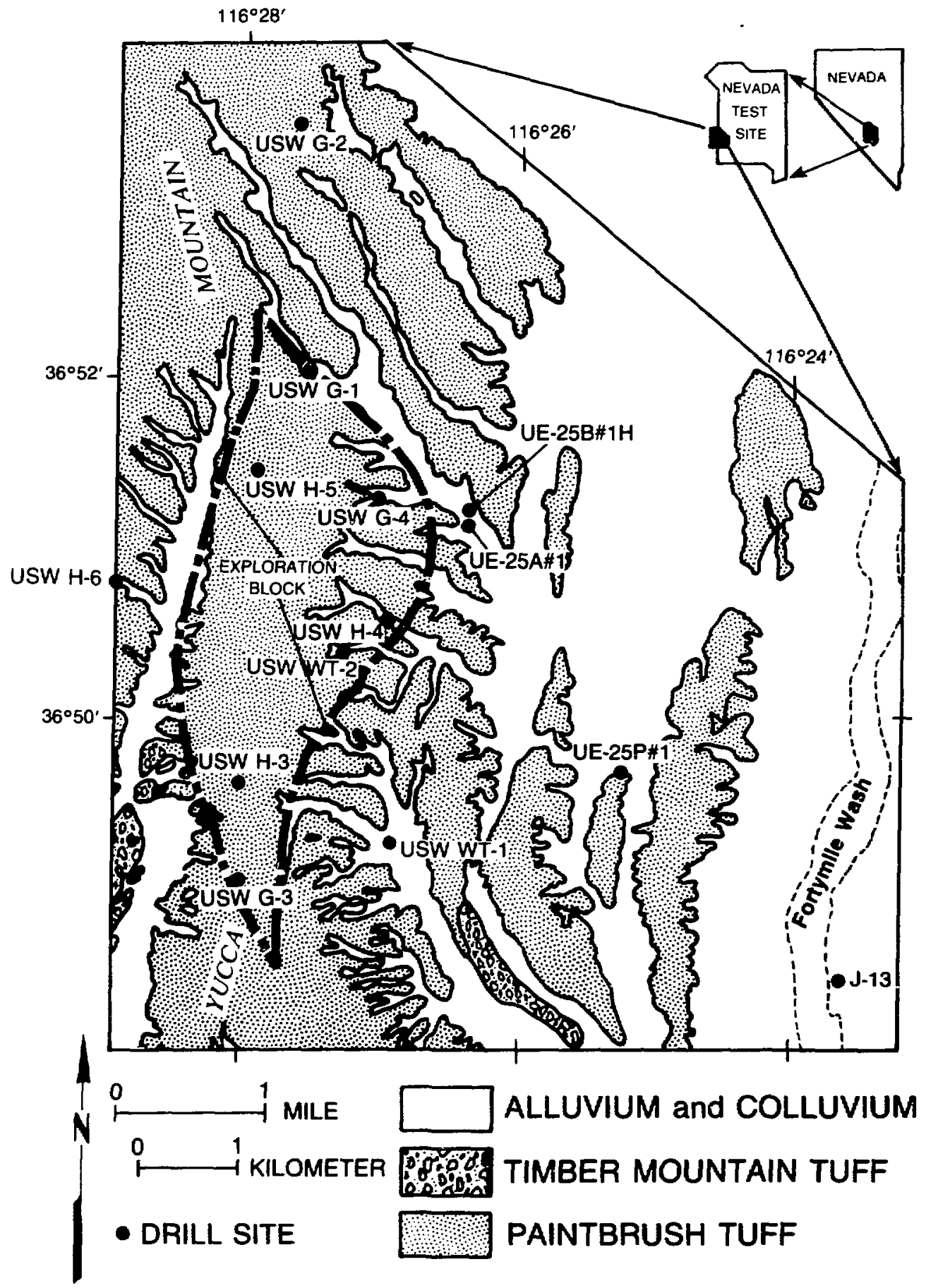

Fig. 1.

Location map showing Yucca Mountain and drill holes. 


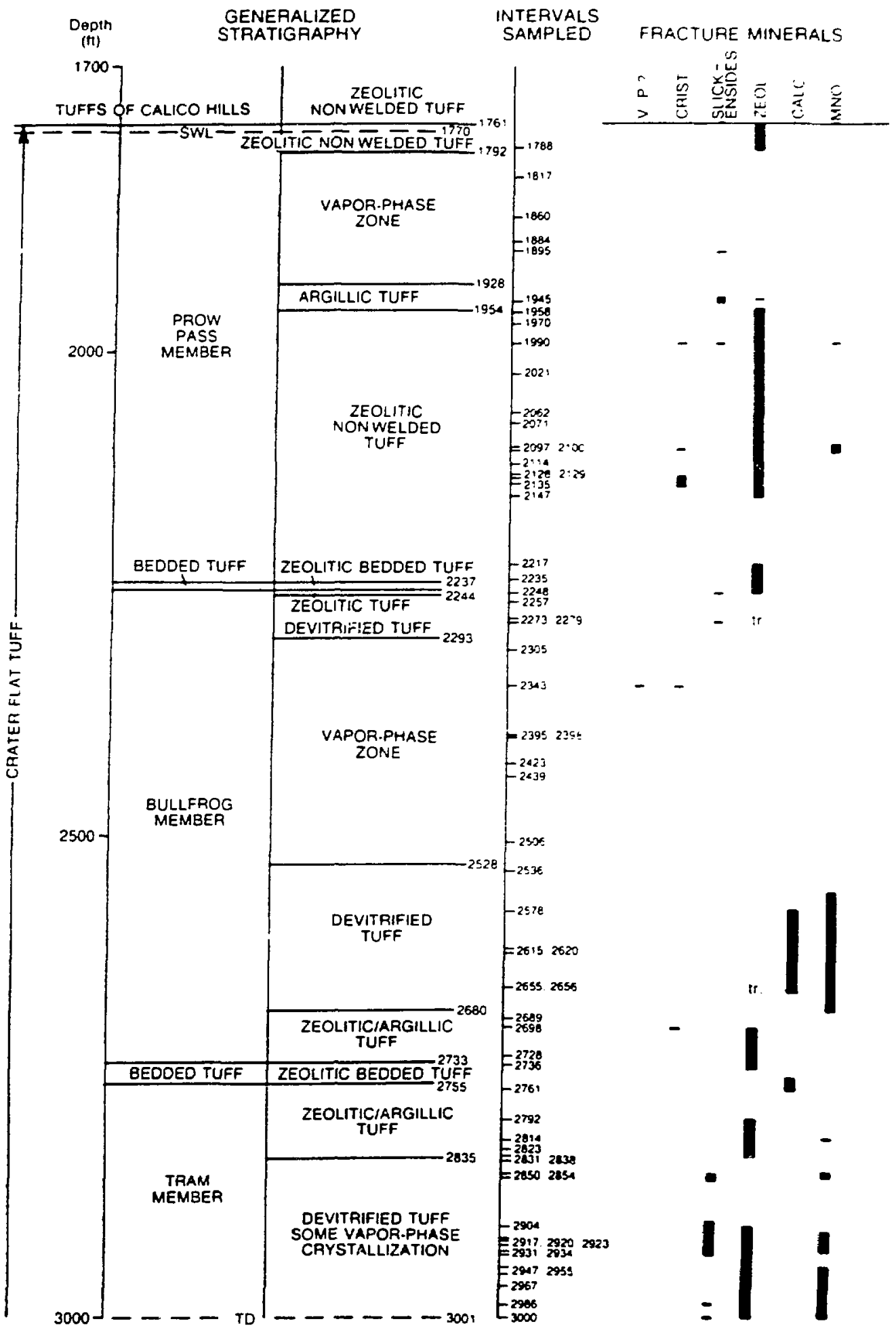

Fig. 2.

Generalized strat graphy, modified from Spengler and Chornack (1984), with intervals sampled and fracture minerals observed in the saturated zone of USW G-4. 
TABLE I. IDEALIZED CHEMICAL FORMULAE FOR MN-OXIDE MINERALS.

Pyrolusite

Hollandite

Cryptomelane

Coronadite

Todorokite

Lithiophorite
$\mathrm{MnO}_{2}$

$$
\begin{aligned}
& \mathrm{Ba}\left(\mathrm{Mn}^{+4}, \mathrm{Mn}^{+3}\right)_{8} \mathrm{O}_{16} \cdot 0.3-0.8 \mathrm{H}_{2} \mathrm{O} \\
& \mathrm{K}\left(\mathrm{Mn}^{+4}, \mathrm{Mn}^{+3}\right)_{8} \mathrm{O}_{16} 0.3-0.8 \mathrm{H}_{2} \mathrm{O} \\
& \mathrm{Pb}\left(\mathrm{Mn}^{+4}, \mathrm{Mn}^{+3}\right)_{8} \mathrm{O}_{16} \cdot 0.3-0.8 \mathrm{H}_{2} \mathrm{O}
\end{aligned}
$$

$(\mathrm{Na}, \mathrm{Ca}, \mathrm{K}, \mathrm{Ba}, \mathrm{Sr})_{0.3-0.7}(\mathrm{Mn}, \mathrm{Mg}, \mathrm{Al})_{6} \mathrm{O}_{12} \cdot 3.2-4.5 \mathrm{H}_{2} \mathrm{O}$

$(\mathrm{Al}, \mathrm{Li}) \mathrm{MnO}_{2}(\mathrm{OH})$

similar to phenomena demonstrated for simple manganese oxides (e.g., Hem, 1978). The factor that makes these Mn oxides potentially important at Yucca Mountain is their occurrence as fracture-lining minerals, where they may easily interact with any flowing water. In contrast to the Mn oxides at Yucca Mountain, the bulk of the Fe oxides (hematite, magnetite, titanomagnetite) at Yucca Mountain occur primarily as microphenocrysts and in the groundmass of the tuffs, although red stains (hematite?) are common in fractures in the Tram Member. It is the occurrence of $\mathrm{Mn}$ oxides along potential transport pathways, coupled with their reactivity, that make these important minerals to study at Yucca Mountain.

\section{METHODS}

\section{A. Microscope}

The entire length of core from the Crater Flat Tuff was examined, and representative samples were taken of each occurrence of black (presumed manganese oxide) fracture coating. These samples were examined using a binocular microscope (50x magnification). Fragments of these samples were chosen for scanning electron microscope (SEM) analysis. Imaging and qualitative composition studies were made on an ISI model DS-130 scanning electron microscope, operated between 15 and $40 \mathrm{Kev}$. The SEM photographs in this report are of secondary-electron images (SEI) unless identified as backscattered-electron image (BSE). 


\section{B. X-ray Diffraction}

Samples for X-ray diffraction (XRD) analysis were scraped from fracture surfaces with a steel or tungsten carbide scraper and were hand-picked under the binocular microscope to remove as much of the rock matrix as possible. The scraped samples consisted of all the minerals coating an individual fracture, and no attempt was made to segregate the manganese oxide minerals. The samples were then powdered in a ceramic mortar and pestle and mounted either in cavities or as water-smear samples, depending on the amount of material available. Watersmear samples were mounted on "zero-background" cut quartz plates. XRD patterns were obtained in the step-scan mode with an automated Siemens D-500 powder diffractometer using a $\mathrm{Cu} X$-ray tube and a graphite diffracted-beam monochromator. Some data were obtained using a solid-state $\mathrm{Si}(\mathrm{Li})$ detector without a diffracted-beam monochromator. Data were collected from at least $2-62^{\circ} 2 \theta$, using $0.02^{\circ}$ steps, and counting for at least $16 \mathrm{~s} / \mathrm{step}$.

Manganese minerals were identified by comparing observed patterns with standards from the JCPDS and with pure standards or calculated XRD patterns for these manganese minerals. As no in-house standard mixtures yet exist of manganese minerals, the absolute abundances of manganese oxide, silicate, and carbonate minerals could not be determined. In sume cases, manganese oxides were visually estimated to be more than half the total fracture coating.

\section{Petrography and Electron Microprobe Analysis}

Thin sections were made whenever possible, but preparing thin sections across some open fractures was impossible because of differential grinding of the softer fracture-filling material. As manganese minerals are often intergrown with silica minerals or calcite, photomicrographs taken in reflected light were used to identify spots for analysis. Elemental compositions were determined using an automated Cameca electron microprobe operated at $15 \mathrm{kV}$ with a sample current of $15 \mu \mathrm{A}$ on thorium oxide. Usually a small $5-\mu \mathrm{m}$ raster was used, but for some analyses a 1- $\mu \mathrm{m}$ spot was necessary. Analyses were made at a minimum of either $20 \mathrm{~s}$ or 30,000 counts for each element. Compositions were calculated from corrected peak intensities using the methods of Bence and Albee (1968). Oxide mineral standards were used if available, but some elements were calibrated using silicate minerals, glasses, or other mineral standards. Because of the difficulty obtaining a manganese standard with manganese in a single oxidation state, the manganese calibration may have resulted in analyses $2-3 \mathrm{wt} \%$ low in $\mathrm{MnO}_{2}$. 
Although the problems of low totals and blistering of the carbon coat due to void space were observed, as described by Frenzel (1976), it was possible to obtain reasonable totals and stoichiometry for at least a few points on most samples. Analyses that totalled over $85 \%$ with $<2 \% \mathrm{SiO}_{2}$ were accepted. Iron oxide analyses with higher $\mathrm{SiO}_{2}$ values were accepted for the sample from $2099 \mathrm{ft}$. Individual oxides were considered not detected if the analyzed amount was $<0.05 \%$ or if the calculated standard deviation based on peak vs background counts was $>50 \%$. These arbitrary cutoffs mean that the detection limits thus defined vary with the element, analyzing crystal, and count time. For some elements, the detection limit is as high as $0.20 \%$, and for other elements the $0.05 \%$ limit is higher than the count uncertainty. Chemical analyses reported in Carlos (1986) do not include all elements detected in these manganese oxides and are superseded by analyses in the Appendix of this report. Energy-dispersive spectra were obtained for most samples, but not on all spots, to ensure that no elements were present that were not included in the analyses.

\section{RESULTS AND DISCUSSION}

Table II gives qualitative mineralogy for fractures containing abundant $\mathrm{Mn}$ - or Fe-oxide phases as determined by $\mathrm{X}$-ray powder diffraction (XRD). The principal Mn-oxide phase in these samples is cryptomelane/hollandite although todorokite is also prominent in some of the samples. Feldspar and mica are not part of the fracture coating but represent rock matrix incorporated into the samples during scraping of the fractures. Reflected-light optical microscopy and electron microprobe chemical analyses were used in several samples to confirm the presence of pyrolusite, coronadite, and todorokite. Figure 3 shows XRD patterns of fracture material from three Mn-oxide bearing samples from drill hole USW G-4. Figure 4 shows XRD patterns for pure samples of cryptomelane/hollandite, pyrolusite, and todorokite for comparison. The sample localities for the three Mn-oxides are Socorro, New Mexico; Elgersberg, Germany; and Charco Redondo, Cuba, respectively.

The prominent Fe-oxide phase found in the fractures is generally hematite. However, the Fe-oxide found in sample G4-1991.4 appears to be pither magnetite or maghemite. Sample G41991.4 is not a simple fracture coating but is a zone of concentrated oxide phases diffused through the rock mairix. The presence of the magnetite-like phase is consistent with the Feoxides found in other matrix samples from Yucca Mountain. 
TABLE II. QUALITATIVE XRD ANALYSES OF FRACTURE SAMPLES CONTAINING Mn- AND Fe-OXIDE PHASES FROM THE CRATER FLAT TUFF IN DRILL HOLE USW G-4.

\begin{tabular}{|c|c|c|c|c|c|c|c|c|c|c|c|c|}
\hline Sample & Smectite & $\underline{\text { Mica }}^{1}$ & $\begin{array}{c}\text { Morden- } \\
\text { ite } \\
\end{array}$ & $\begin{array}{c}\text { Clino- } \\
\text { ptilolite }\end{array}$ & Quartz & $\begin{array}{l}\text { Cristo- } \\
\text { balite }\end{array}$ & Feldspar $^{1}$ & $\begin{array}{c}\text { Crypt- } \\
\text { omelane }^{2}\end{array}$ & $\begin{array}{l}\text { Pyro- } \\
\text { lusite } 3\end{array}$ & $\begin{array}{c}\begin{array}{c}\text { Todoro- } \\
\text { kite }\end{array} \\
\end{array}$ & Hematite & Other \\
\hline USW G4-1991.4 & Major & - & Minor & Major & Minor & $? ? ?^{4}$ & Minor & Major & Minor & - & - & Trace 5 \\
\hline USW G4-2099.3/2099.4 & - & - & Minor & Major & Trace & Minor & - & Major & Minor & $\cdots$ & - & Trace $^{6}$ \\
\hline USW G4-2615.8/2615.9 & Trace & - & - & - & Major & - & Major & Major & - & Minor & - & -- \\
\hline USW G4-2854.5/2854.7 & Trace & Minor & -- & - & Majo: & - & Major & Minor & $? ? ?$ & - & Minor & - \\
\hline USW G4-2917 & Trace & Trusce & $\cdots$ & -- & Major & - & Major & Major & $? ? ?$ & $? ? ?$ & Trace & - \\
\hline USW G4-2920.5/2920.6 & Minor & Minor & - & -- & Major & - & Major & - & - & - & Minor & - \\
\hline USW G4-2947.3 & Trace & - & -- & - & Major & -- & Minor & Major & $? ? ?$ & $? ? ?$ & - & - \\
\hline USW G4-2954.8/2955.1 & Minor & Minor & - & - & Major & - & Minor & Major & $? ? ?$ & Minor & - & - \\
\hline USW G4-2967.4/2967.5 & Trace & - & 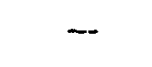 & - & Major & - & Minor & Major & $? ? ?$ & $? ? ?$ & - & - \\
\hline USW G4-2985.6/2986.0 & Minor & Minor & - & - & Major & $\cdots$ & Minor & Minor & - & - & Trace & - \\
\hline
\end{tabular}

1 From rock matrix which got incorporated into sample during scraping.

${ }^{2}$ Cryptomelane group mineral: Cryptomelane-Hollandite.

${ }^{3}$ Identification assisted using an optical microscope and electron microprobe.

4 Believed to be present based on a limited number of reflections.

${ }^{5}$ Magnetite or Maghemite, oxidation state is not known.

${ }^{6}$ Coronadite. Identification made using an optical microscope and electron microprobe. 

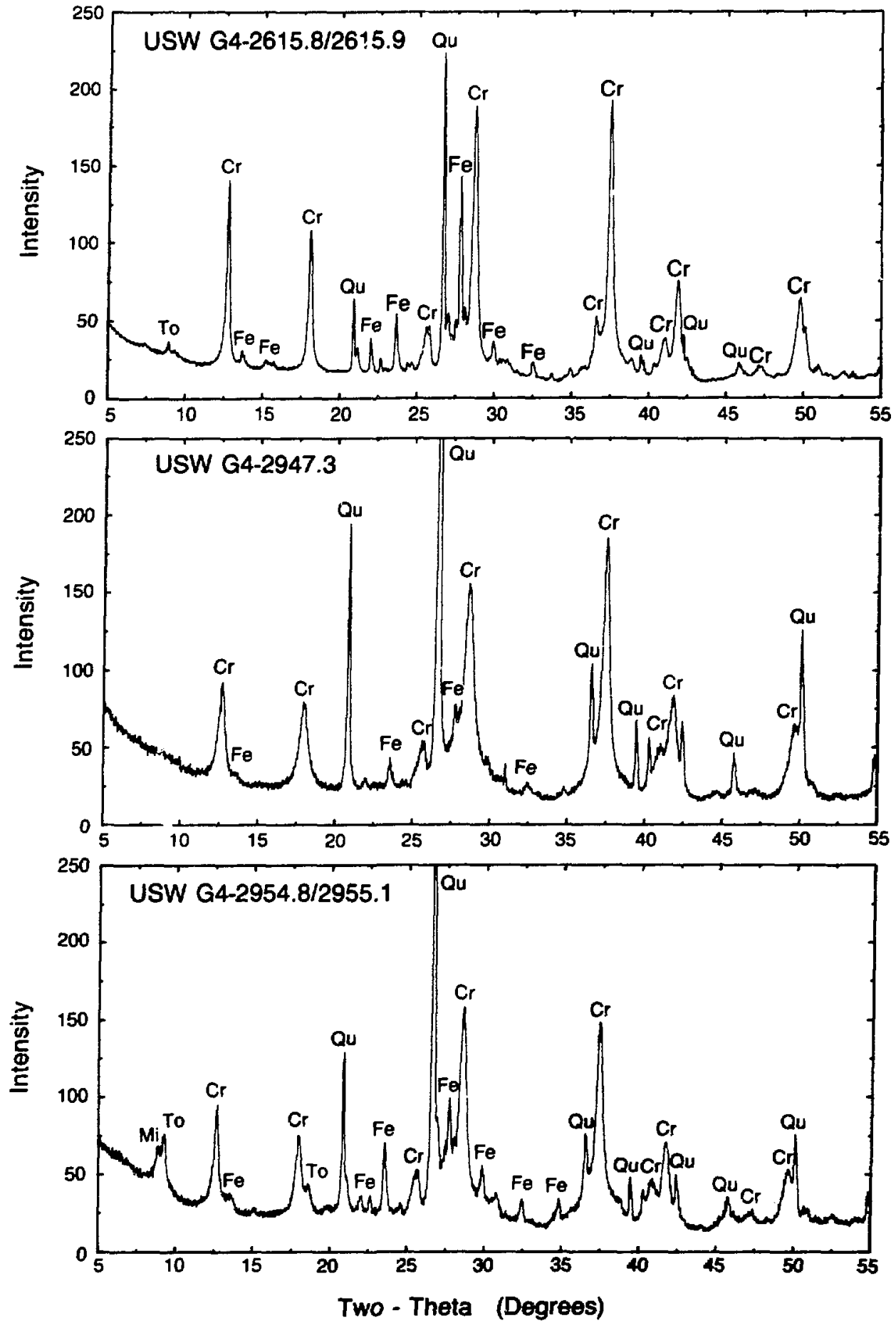

Fig. 3.

$\mathrm{X}$-ray diffraction patterns for several Mn-oxide-bearing fractures from the Crater Flat Tuff in drill core USW G-4. $\mathrm{Cr}=$ cryptomelane, $\mathrm{To}=$ todorokite, $\mathrm{Qu}=$ quartz, $\mathrm{Fe}=$ feldspar, $\mathrm{Mi}=$ mica. Feldspar and mica are rock matrix material incorporated into the sample during scraping of the fracture materia! 

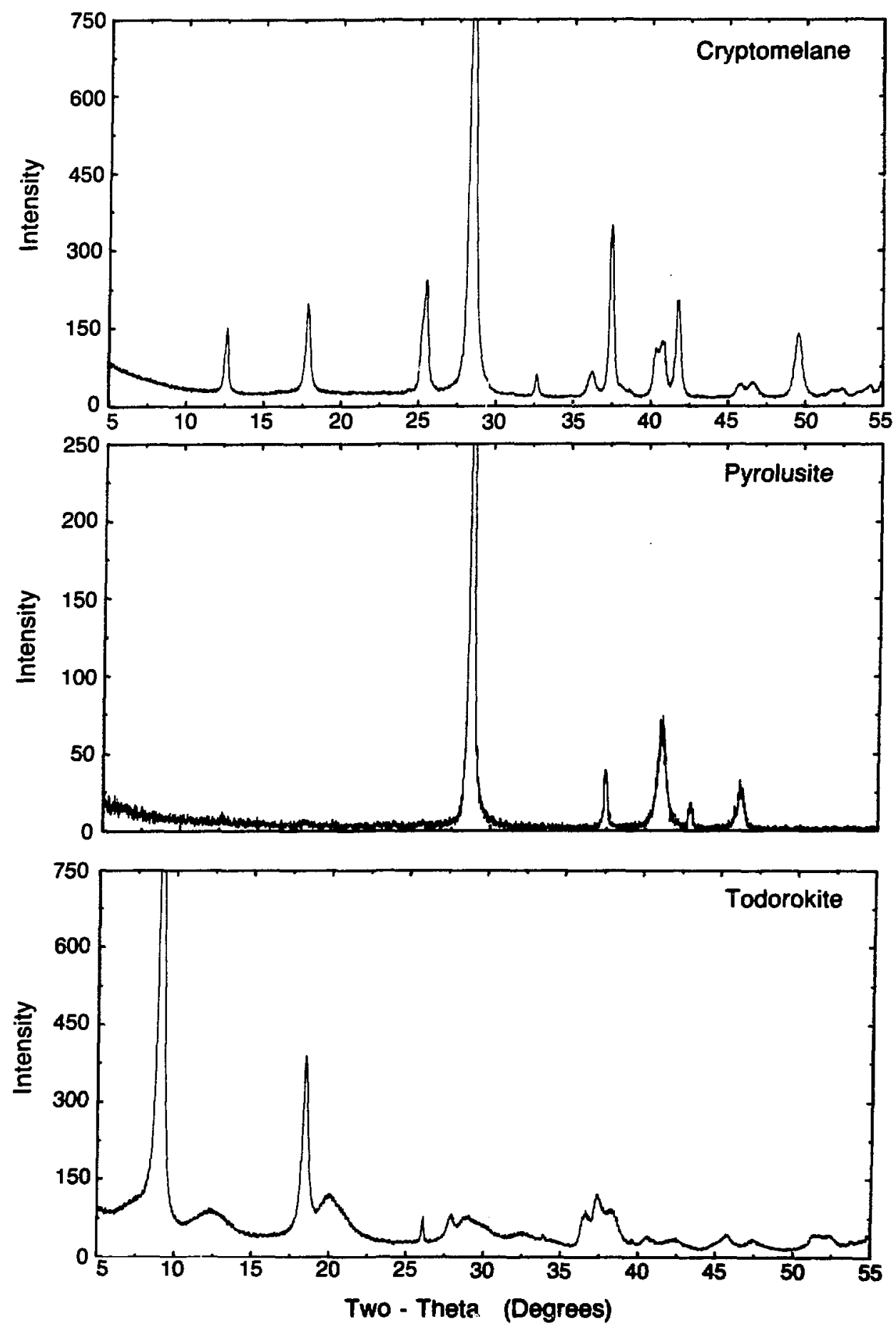

Fig. 4.

X-ray diffraction patterns for pure Mn-oxide phases: cryptomelane/hollandite from Socorro, New Mexico; pyrolusite from Elgersberg, Germany; todorokite from Charco Redondo, Cuba. 


\section{A. Distribution of Manganese Oxides in the Prow Pass Member}

Manganese oxides occur in two discrete fracture intervals in the Prow Pass Member, from 1990 to $1991 \mathrm{ft}$ and from 2099 to $2100 \mathrm{ft}$. In both occurrence and mineralogy they are unlike the manganese-oxide fracture coatings in the Bullfrog and Tram Members of the Crater Flat Tuff. The Prow Pass Member in USW G-4 consists of non- to partially-welded tuff with both zeolitic and vapor-phase intervals (Fig. 2). The manganese-oxide minerals occur in the zeolitic intervals.

Two manganese-oxide minerals (cryptomelane and pyrolusite) are found infiltrating the matrix and filling voids along a fault plane intersected by the drill hole at 1990-1991 ft. The manganese minerals are intergrown with silicate phases and red-brown iron oxides throughout most of the interval (Fig. 5). Only in voids created by opening of fractures or internal voids in zeolitic shards were the manganese minerals sufficiently concentrated to be analyzed by microprobe. Two distinct phases can be identified both in reflected light and by chemistry. The most abundant phase is cryptomelane/hollandite which occurs as intergrown rods a few $\mu \mathrm{m}$ in length. In reflected light it is grey-white in color and slightly bireflectant. Pyrolusite occurs as single crystals (or planar-sided masses) intergrown with the cryptomelane in void spaces (Fig. 6) and partially replacing a phenocryst. It has a yellow-beige color and is bireflectant from slightly beige to distinctly yellow-beige. In reflected light the cryptomelane is polished and appears smooth, whereas the surface of the pyrolusite appears rough (Fig. 6). The iron oxide occurs as a red-brown stain streaked through the matrix but is not obvious in reflected light as a distinct phase. Chemical compositions of the manganese minerals determined by electron microprobe are given in the Appendix. Data published in Carlos (1987) are included here except for the pyrolusite analysis. The previous analysis (Carlos, 1987, p. 12) was of intergrown minerals and is replaced by the pyrolusite analyses in the Appendix.

The second occurrence of manganese oxides in fractures in the Prow Pass Member is in several subhorizontal fractures over an interval of about 2 inches in the core at $2100 \mathrm{ft}$ depth. These fractures in the zeolitic tuff are lined with cristobalite, clinoptilolite, mordenite, iron oxide, and manganese oxide minerals. Manganese oxides have infiltrated the matrix adjoining the larger zeolite-filled fractures and fill clinoptilolite-rimmed shards within the infiltration zone. The manganese mineral within small shards and filling small monomineralic fractures is hollandite. Although hollandite fills shards and may be interstitial to clinoptilolite in fractures

containing clinoptilolite and cristobalite, there are also clinoptilolite-cristobalite-lined fractures which have open spaces that are not filled. One fracture contains a complex filling of 


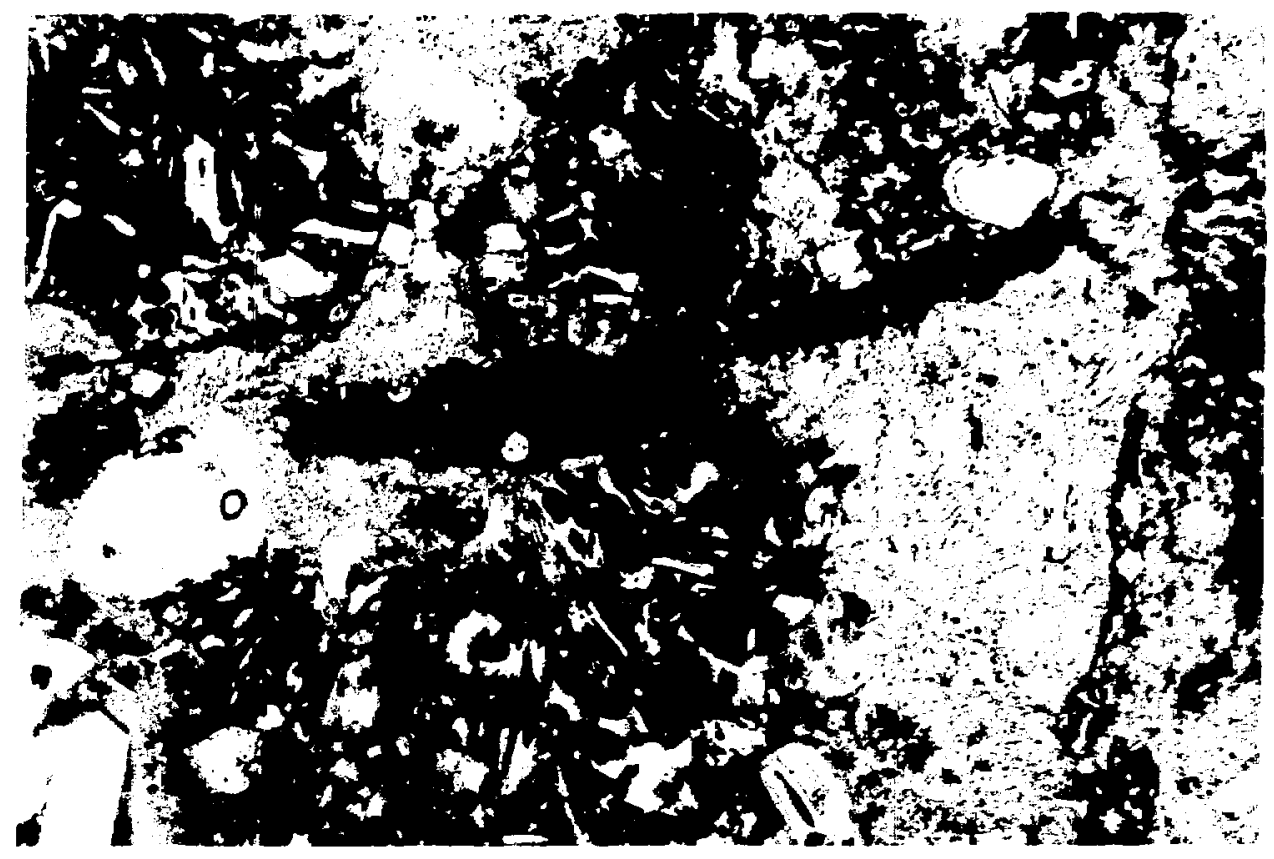

Fig. 5.

Photomicrograph of manganese and iron oxides infiltrating matrix and filling voids at $1991 \mathrm{ft}$ depth. Transmitted light; field of view is $2.5 \mathrm{~mm}$.

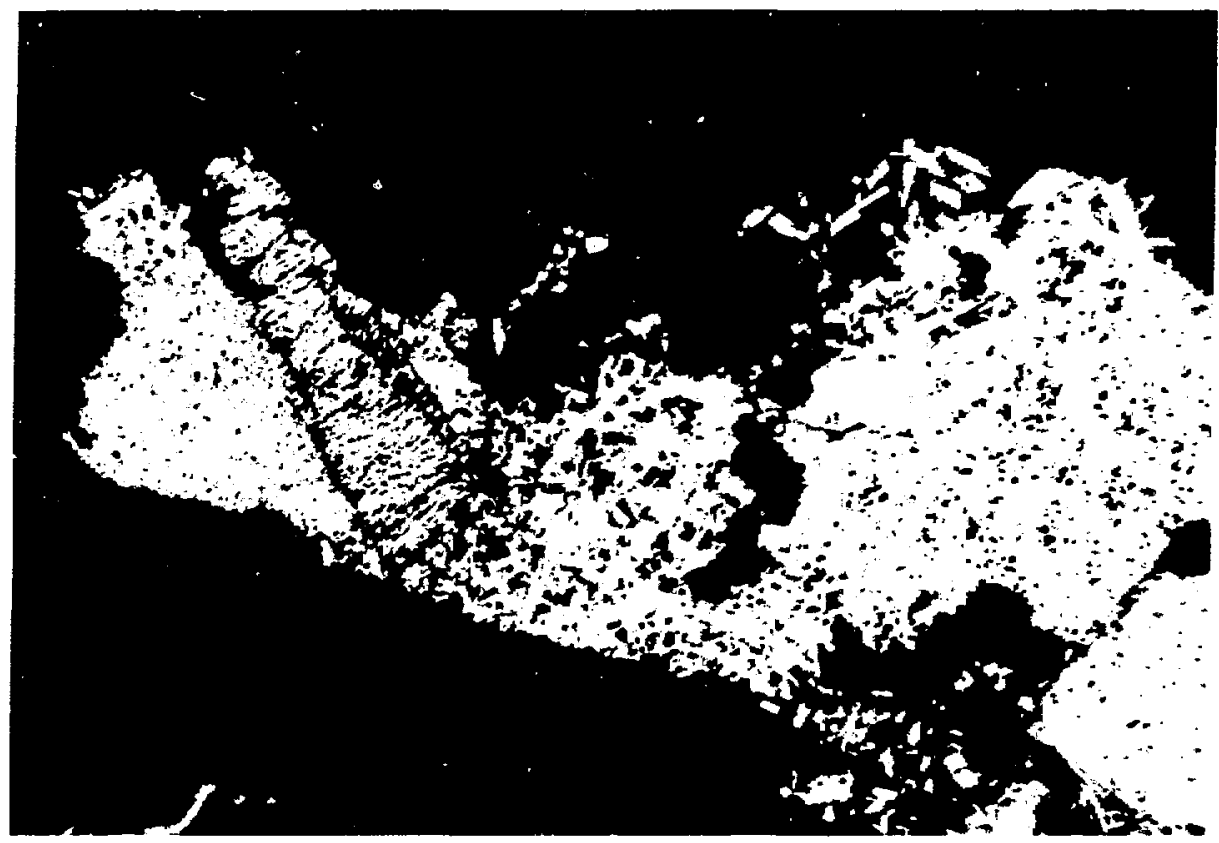

Fig. 6.

Photomicrograph of pyrolusite (yellowish) and cryptomelane (gr, v) filling void at $1991 \mathrm{ft}$, an enlargement of far right of right hand void in Fig 4. Reflected light, polarizer out. Field of view is $0.2 \mathrm{~mm}$. 
clinoptilolite rimmed with cristobalite followed by balls of iron oxide and radiating clusters of pyrolusite (Fig. 7). The central void space is filled with hollandite intergrown with a silicate phase. Based on morphology and qualitative chemistry determined with the SEM (Fig. 8), the silicate phase is probably mordenite.

A single irregular particle of lead-rich manganese oxide, probably coronadite, occurs on top of the cristobalite along one edge of a part of the fracture that contains no pyrolusite (Fig. 9). This material was incorrectly identified as pyrolusite by Carlos (1987) because lead was not included in the microprobe analyses and reflected light was not used for examination of thin sections described in that study. Microprobe analyses of iron and manganese oxides in this fracture are given in the Appendix. Data from Carlos (1987) are included except for the phases in which lead is a major element, because lead was not included in the earlier analyses. All phases reported in Carlos (1987) have been re-analyzed and the analyses are included in the Appendix.

At least two distinct crystals in this fracture (indicated by an $x$ on Fig. 7 ) contain subequal amounts of $\mathrm{Pb}$ and $\mathrm{Ba}$, demonstrating that there is at least a partial solid solution between hollandite $(\mathrm{Ba})$ and coronadite $(\mathrm{Pb})$. Although two different $\mathrm{Ba} / \mathrm{Pb}$ ratios were obtained on two analyses of the same crystal, neither zoning nor intergrowth within these crystals is evident in $\mathrm{SEM}$ backscattered electron images, where the difference in $\mathrm{Ba}$ and $\mathrm{Pb}$ should be visible. The individual crystals are too small $(5-20 \mu \mathrm{m})$ to measure a zoning profile with the electron microprobe. The sequence of mineral deposition is illustrated by the photomicrographs in Figs. 7 and 9.

The shard-filling hollandite is similar in chemistry to that of hollandite in the fractures in this interval, although it has slightly less Ba and more $\mathrm{K}$. Analyses of shard-filling hollandite are included at the end of the Appendix. Manganese oxides diffused into the matrix could not be analyzed because of small grain size and intergrowth with silicate phases, but the morphology and color in reflected light suggest that hollandite predominates.

\section{B. Distribution of Manganese Oxides in the Bullfrog Member}

Manganese oxide minerals occur in almost all fractures in the moderately and densely welded devitrified interval of the Bullfrog Member between 2559 and $2680 \mathrm{ft}$ depth in USW G-4. The manganese minerals are of the cryptomelane/hollandite group and occur with quartz in near vertical fractures and usually with quartz and calcite in sub-horizontal fractures. The subhorizontal fractures often offset the near verticai fractures by at least a few $\mathrm{mm}$, and in some 


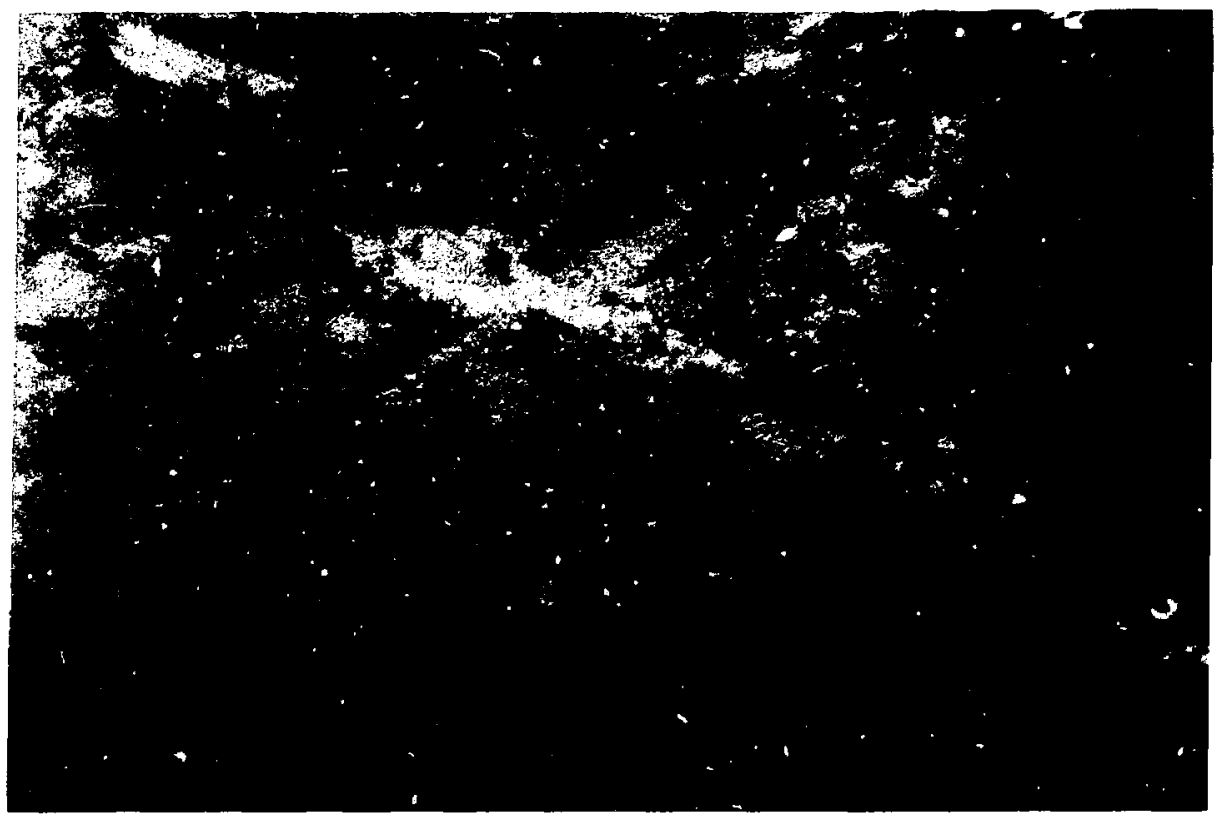

Fig. 7.

Photomicrograph of fracture at $2099 \mathrm{ft}$ showing sequence of deposition. Reflected light, polarizer out. $\mathrm{Cl}=$ clinoptilolite, $\mathrm{Cr}=$ cristobalite, $\mathrm{I}=$ iron oxide, $\mathrm{Py}=$ pyrolusite, $\mathrm{Ho}=$ hollandite. Field of view is $0.2 \mathrm{~mm}$. Grains with intermediate $P b$ (see text) are indicat?d by $x$.

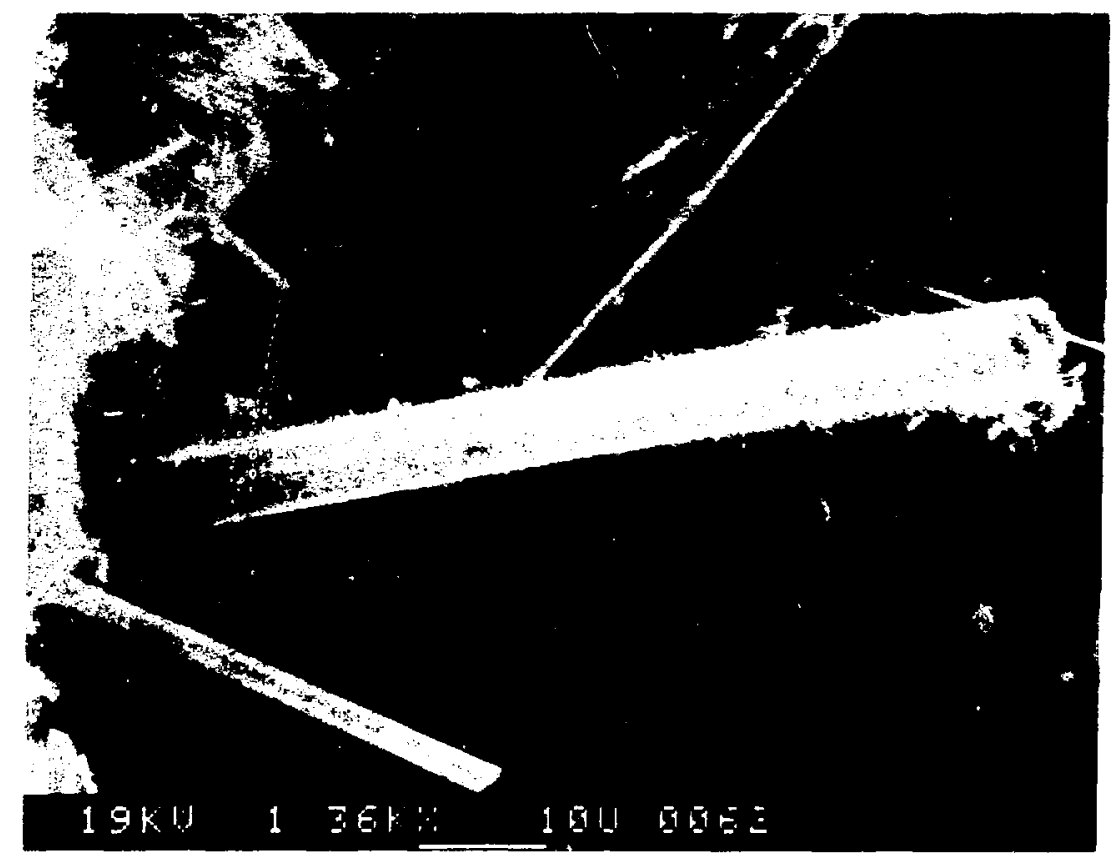

Fig. 8.

SEM image of rods of hollandite with fibers of mordenite on and around them. Cristobalite forms balls in background. 
cases they appear to terminate the vertical fractures but may merely offset them by more than the core diameter. The quartz plus manganese-oxide fractures are generally intact in the core, but many of the sub-horizontal fractures are open. Four samples in this interval (containing four closed and two open fractures) were examined.

An open fracture containing manganese oxide, quartz, and calcite from $2578 \mathrm{ft}$ was examined using the SEM. A mat of hollandite overlies terminated quartz (Fig. 10). Calcite, not shown, covers both phases in part of the fracture.

A sub-horizontal fracture at $2615 \mathrm{ft}$ contains two intergrown phases, todorokite and hollandite, identified by XRD and distinguishable in SEM backscattered-electron images of the polished thin section. Although there is no measurable of fset on the fracture, it contains brecciated fragments of the phenocrysts and pumice that it crosses. Figure 11 illustrates the texture of the fracture filling. Qualitative energy-dispersive analyses made during SEM examination of the thin section indicate that todorokite is the predominant phase in the closed portion of the fracture, but microprobe analyses may include some intergrown hollandite because the two minerals could not be distinguished during analysis. The void spaces between individual needles of manganese oxide resulted in low totals during microprobe analysis. The part of the fracture that was open is more complex. Hollandite appears to be the more abundant phase in the open part of the fracture as judged by XRD analysis. Casts of a dissolved rectangular mineral can be seen in the manganese oxide (Fig. 12). A cellular coating, possibly cristobalite or smectite, lines the casts.

A closed fracture filled with manganese oxide, calcite, and silica was intersected by the core at $2620 \mathrm{ft}$ depth. In some places this sub-horizontal fracture brecciates matrix and phenocrysts as does the fracture at $2615 \mathrm{ft}$, but these sections of the fracture are not filled with manganese oxide. The photomicrograph in Fig. 13 shows that silica and manganese oxide were the first minerals to line the fracture. Manganese oxide and silica have diffused into the matrix surrounding the fracture. Calcite later filled the fracture. Sprays of hollandite needles are enclosed in the calcite, and in some places the intergrown manganese oxide and calcite are opaque in transmitted light.

In a near-vertical fracture from $2655-2656 \mathrm{ft}$, manganese oxides are intergrown with quartz in the fracture and have diffused into the matrix in the silicified border of the fracture. This fracture is offset 1 to $4 \mathrm{~mm}$ by two sub-horizontal fractures containing quartz and calcite, with 


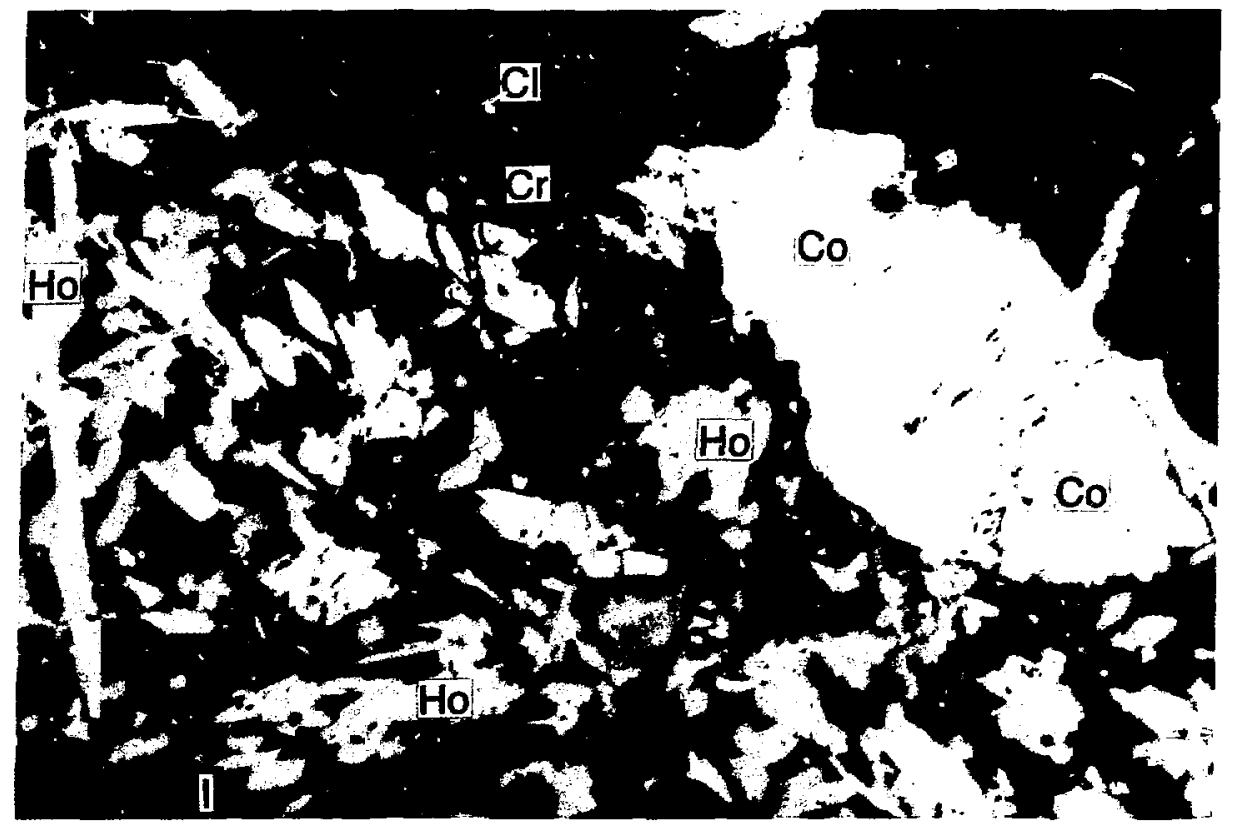

Fig. 9.

Photomicrograph of coronadite in fracture at $2099 \mathrm{ft} . \mathrm{Cl}=$ clinoptilolite, $\mathrm{Cr}=$ cristobalite, $\mathrm{I}=\mathrm{iron}$ oxide, $\mathrm{Co}=$ coronadite, $\mathrm{Ho}=$ hollandite. Field of view is $0.2 \mathrm{~mm}$. Reflected light with partially crossed polars to emphasize grain boundaries within coronadite.

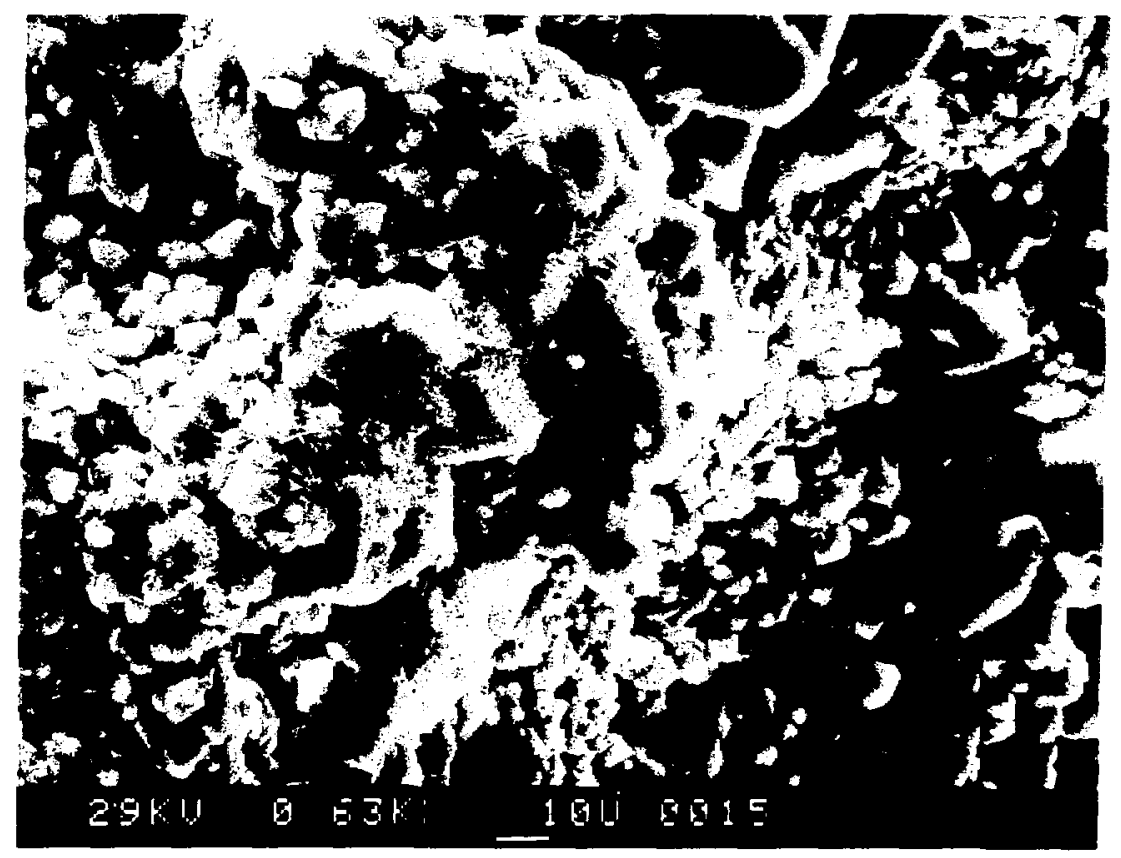

Fig. 10.

SEM image of hollandite over quartz in fracture at $2578 \mathrm{ft}$. 


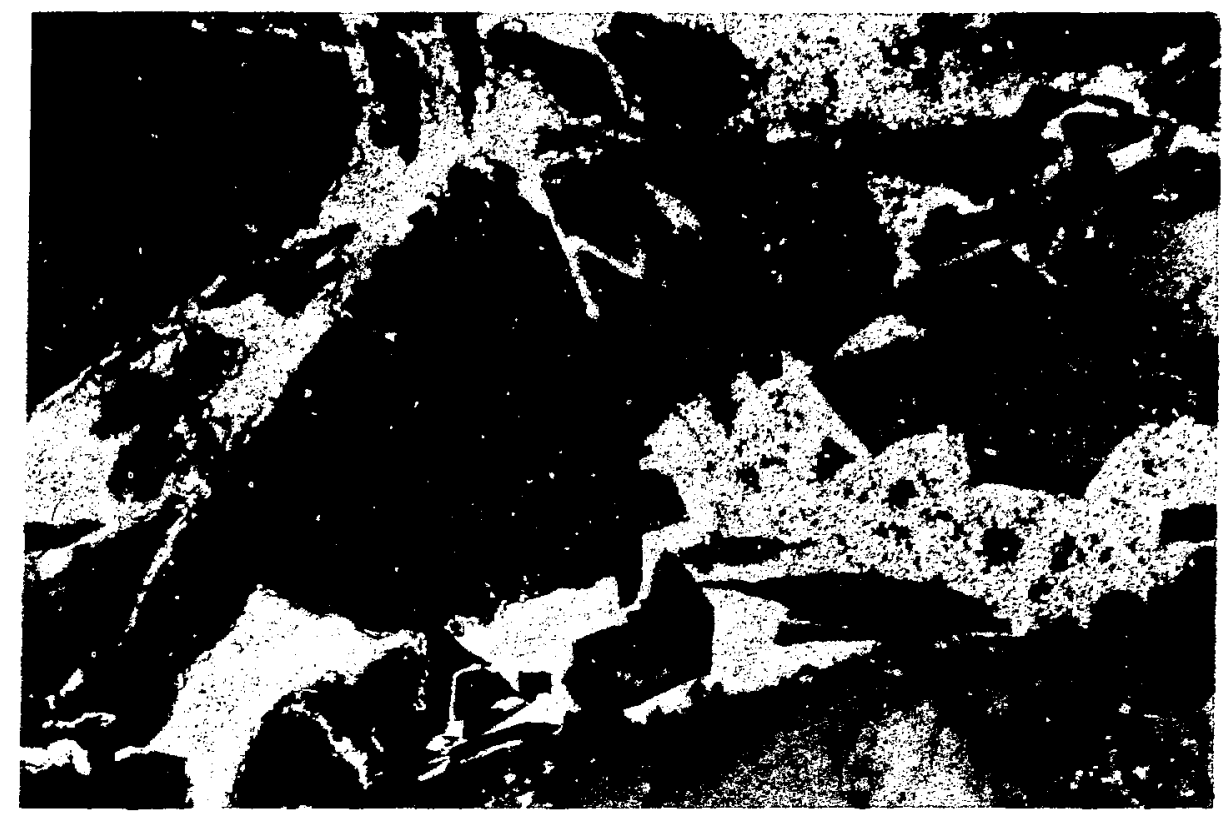

Fig. 11.

Photomicrograph of fracture at $2615 \mathrm{ft}$. Reflected light, field of view is $1 \mathrm{~mm}$.

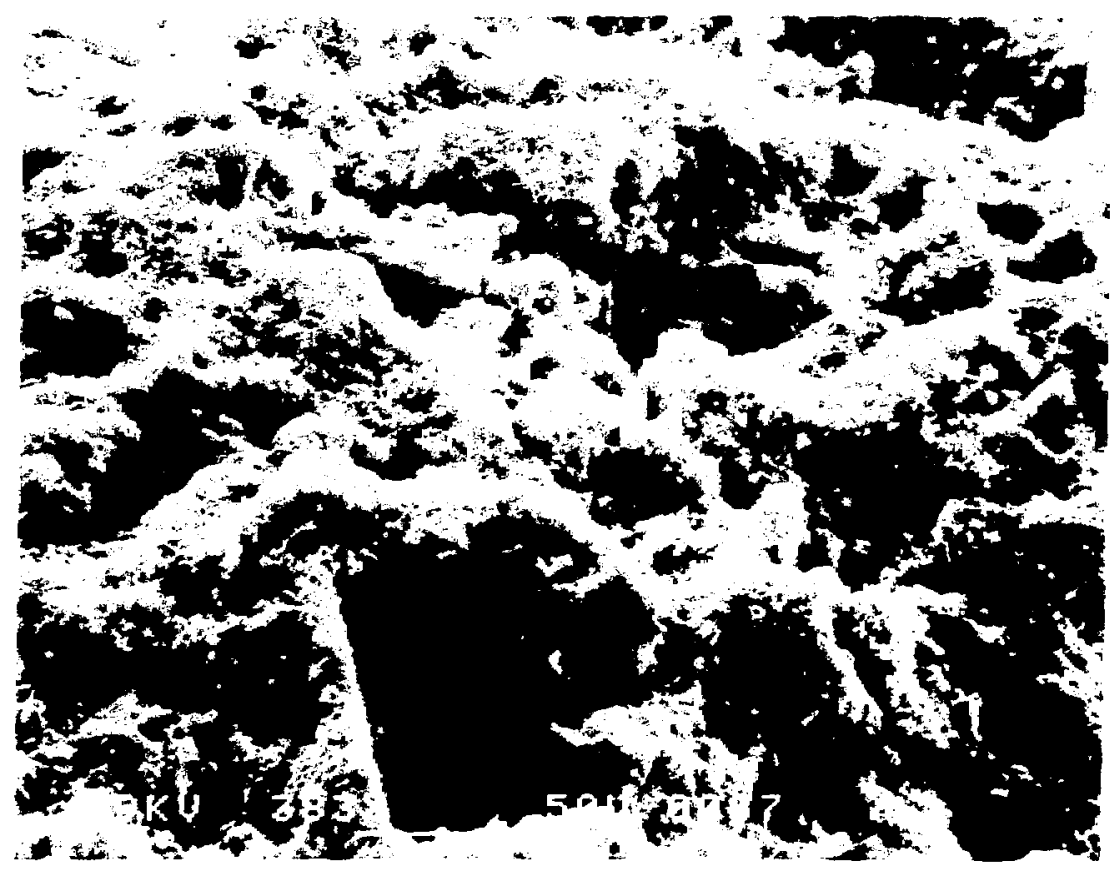

Fig. 12 .

SEM image of fracture surface from $2615 \mathrm{ft}$. 
minor manganese oxides. One of these sub-horizontal fractures has a complex mineralogy including clinoptilolite and traces of mordenite. It is described more fully in Carlos (1987).

Microprobe analyses for minerals in the vertical and sub-horizontal fractures are given in the Appendix. The morphology of the rnanganese oxides in all samples examined in this interval is similar, but the ciiemistry is different for each sample. Only the fracture at $2615 \mathrm{ft}$ contained sufficient material for X.RD an:alysis, and that sample cortains both todorokite and cryptomelane/hollandite. In most cases those minerals cannot be visually distinguished, and microprobe analyses may include both minerals individually or as intergrowths. Data from Carlos (1987) that meet the acceptance criteria defined in the methods section of this report are included in the Appendix, even though lead was not included in the analyses, because lead is not a major constituent of the manganese oxides in this interval.

\section{Distribution of Manganese Oxides in the Tram Member}

Manganese oxide minerals occur in or along fractures from $2814 \mathrm{ft}$ to TD in USW G-4. Cryptomelane/hollandite-family minerals dominate, but todorokite was identified by XRD in some of the samples. As in the Prow Pass Member, the chemistry of these manganese oxides is variable, often within a singie sample. Some of the apparent variability may be the result of intergrowth of more than one manganese oxide phase and/or of intergrowth of manganese and iron oxides.

Horizontal to sub-horizontal bands of red-purple discoloration occur in the zeolitic tuff from about $2755 \mathrm{ft}$ to $2820 \mathrm{ft}$. In the sample at $2814 \mathrm{ft}$, manganese oxides have infiltrated asymmetrically into the matrix on both sides of the fracture, imparting a purplish tint to the rock in a band $1.2 \mathrm{~cm}$ thick. The sub-horizontal fracture is not filled. Manganese oxides occur as intergrown sprays of needles or blades, interstitial to clinoptilolite, filling small fractures and dissolved shards adjacent to the main fracture (Fig. 14). The manganese oxide, probably hollandite, is slightly bireflectant from light to dark grey. Microprobe analyses for this sample are given in the Appendix.

High-angle fractures containing iron and manganese oxides occur from about $2850 \mathrm{ft}$ to TD. Iron- and manganese-rich intervals may alternate along the length of a fracture, or the two may occur together. Most of these fractures do not have coatings along single fracture traces; often visible discoloration occurs as a series of wavy lines forming a band up to $2 \mathrm{~cm}$ wide. Even along fractures that appear to have single-coated surfaces, microscopic examination reveals 


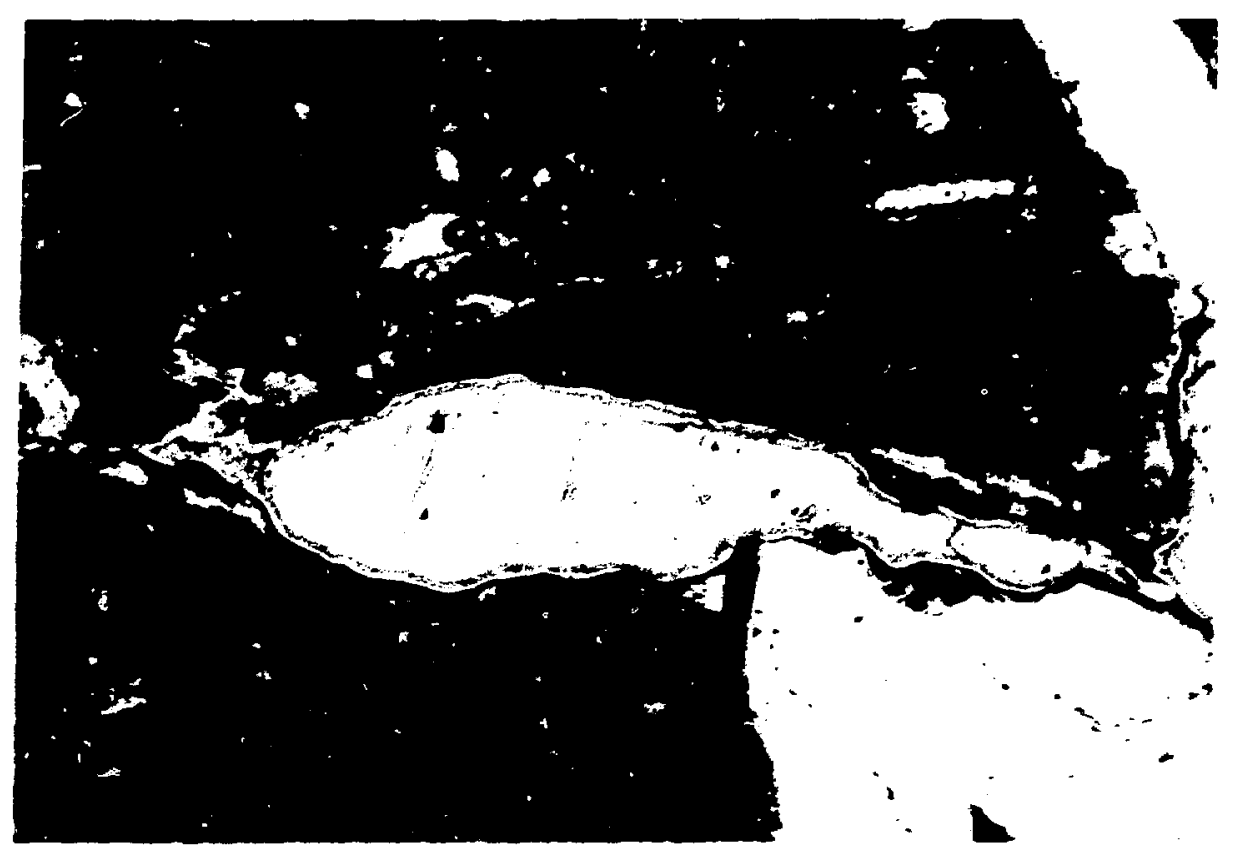

Fig. 13.

Photomicrograph of fracture at $2620 \mathrm{ft}$. Manganese oxide and silica rim fractures, clear (sheared) calcite fills center. Field of view is $2.5 \mathrm{~mm}$.

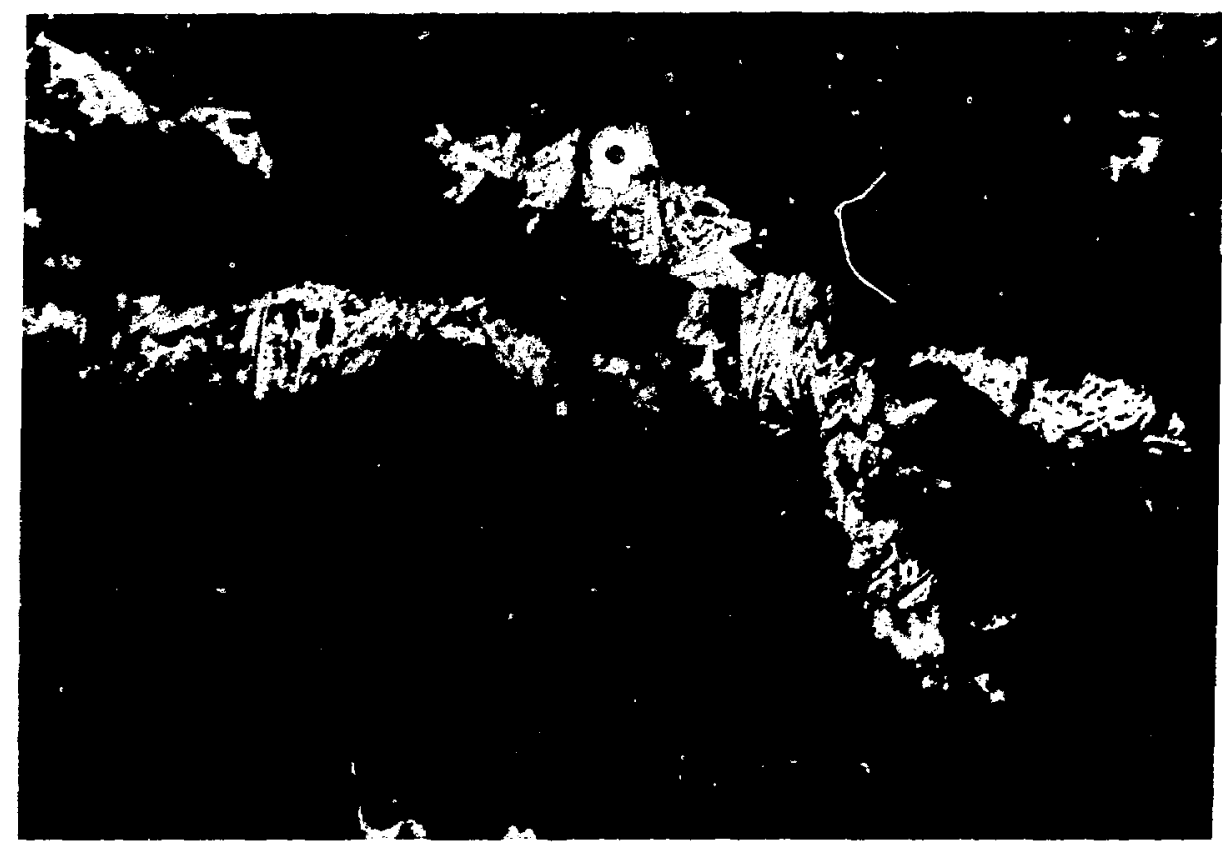

Fig. 14.

Photomicrograph of manganese oxide filling small fractures adjacent to main (empty) fracture from $2814 \mathrm{ft}$. Reflected light. Field of view is $0.2 \mathrm{~mm}$. 
infiltration of manganese oxide into the matrix and often intergrowth with spherulites in the matrix along the edge of the fracture. Away from the fracture, manganese oxides often occur associated with or replacing phenocrysts, especially biotite or lithic fragments. Isolated patches of intergrown manganese oxide and silicate matrix are also observed in thin sections. Iron oxide occurs as red-brown staining intergrown with silicate minerals along the fractures.

In the fracture at $2850 \mathrm{ft}$, a red-brown stain coats many anastomosing fractures in a band about $1 \mathrm{~cm}$ wide. Although the color is noticeable, the iron oxide is too diffuse to be separated from the matrix and identified by XRD in this sample. In samples where the red-brown iron has been identified, it is hematite. The fracture sampled at $2854 \mathrm{ft}$ was open in the core and may be a rubble-filled fracture probably a few $\mathrm{mm}$ wide that was later filled with iron and manganese oxides. It contains sub-rounded and angular fragments of matrix and phenocrysts surrounded by manganese and iron oxides intergrown with fine-grained silicate and partially spherulitic matrix (Fig. 15). SEM backscattered-electron (BSE) images of a thin section across the fracture clearly show three manganese oxide phases (Fig. 16). The phase that appears intermediate grey in this picture was deposited first. EDS spectra indicate $\mathrm{Ba}, \mathrm{Ca}, \mathrm{K}$, and $\mathrm{Sr}$ along with the $\mathrm{Mn}$. In other samples, the presence of $\mathrm{Ca}$ and Sr suggest todorokite, and that may be the mineral here.

Pyrolusite, dark grey in BSE images and bireflectant cream to grey in reflected light, replaces the first mineral around the edges of void space and as prismatic crystals within the original manganese oxide. Hollandite, determined by its chemistry and morphology, is the latest manganese mineral; it occurs as veinlets cutting both the two earlier minerals and as euhedral rods protruding into void space. It is the brightest grey in Fig. 16 and bireflectant grey-white to grey in reflected light.

Microprobe analyses were performed on the three phases seen in the SEM image. Those analyses are given at the end of the table for this sample in the Appendix, and the locations are indicated on the SEM photo with $x$. Even with the aid of the SEM photo to guide analysis, none of the analyses appear to be of pure phases. Analyses of the latest hollandite are notable for their $W$ content of 2-2.9\%. No evidence of an intergrown phase such as wolframite was seen on SEM images at 3000x magnification. It was not possible to determine in reflected light or with the SEM whether the areas which appear intermediate grey in Fig. 16 are slightly bireflectant massive intergrowths of a single cryptocrystalline phase or if more bireflectant hollandite occurs as minute $(<1 \mu \mathrm{m})$ rods within the older hollandite or todorokite. Since most of the analyses in the Appendix are of these areas, they may represent two intergrown phases. Analysis 6 was an 


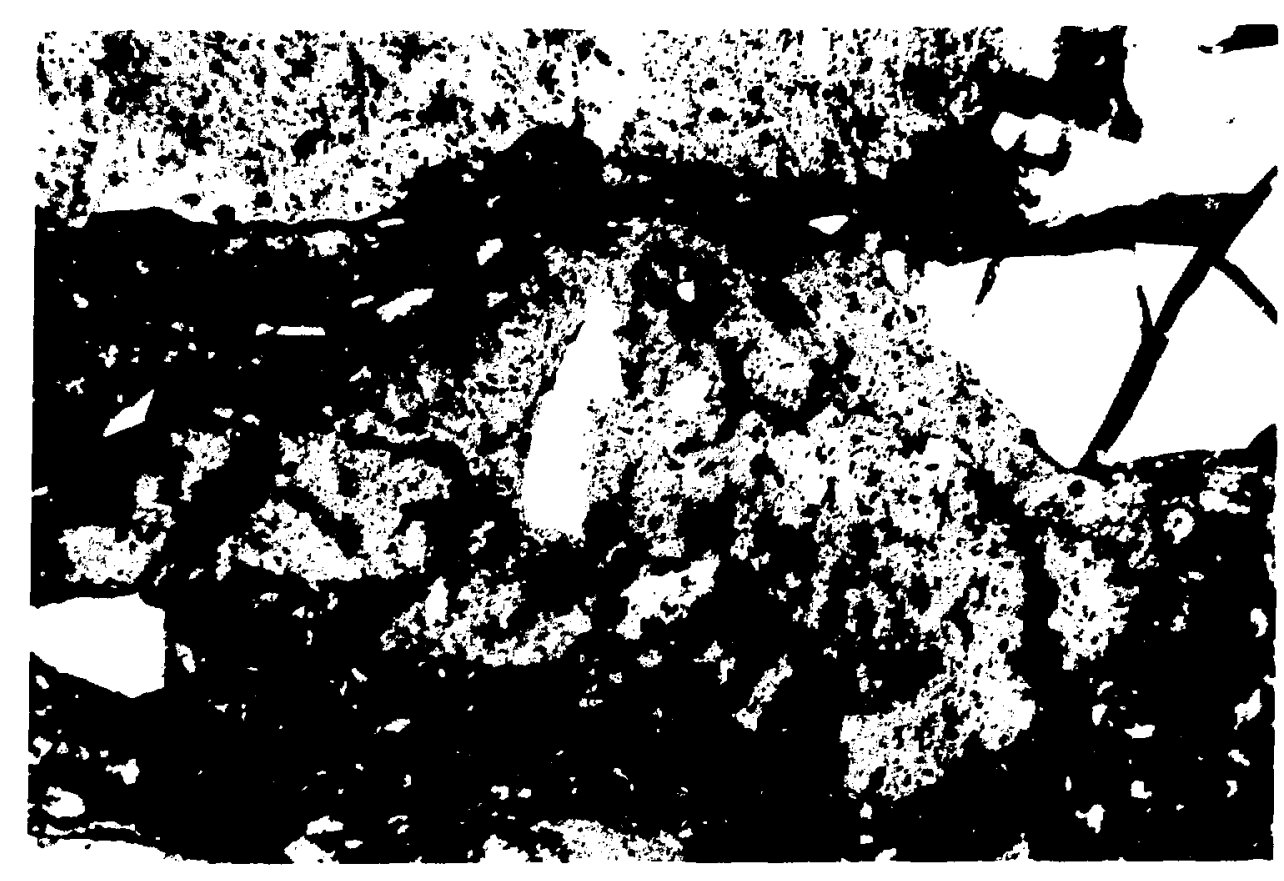

Fig. 15.

Photomicrograph of fracture at $2854 \mathrm{ft}$. Field of view is $2.5 \mathrm{~mm}$.

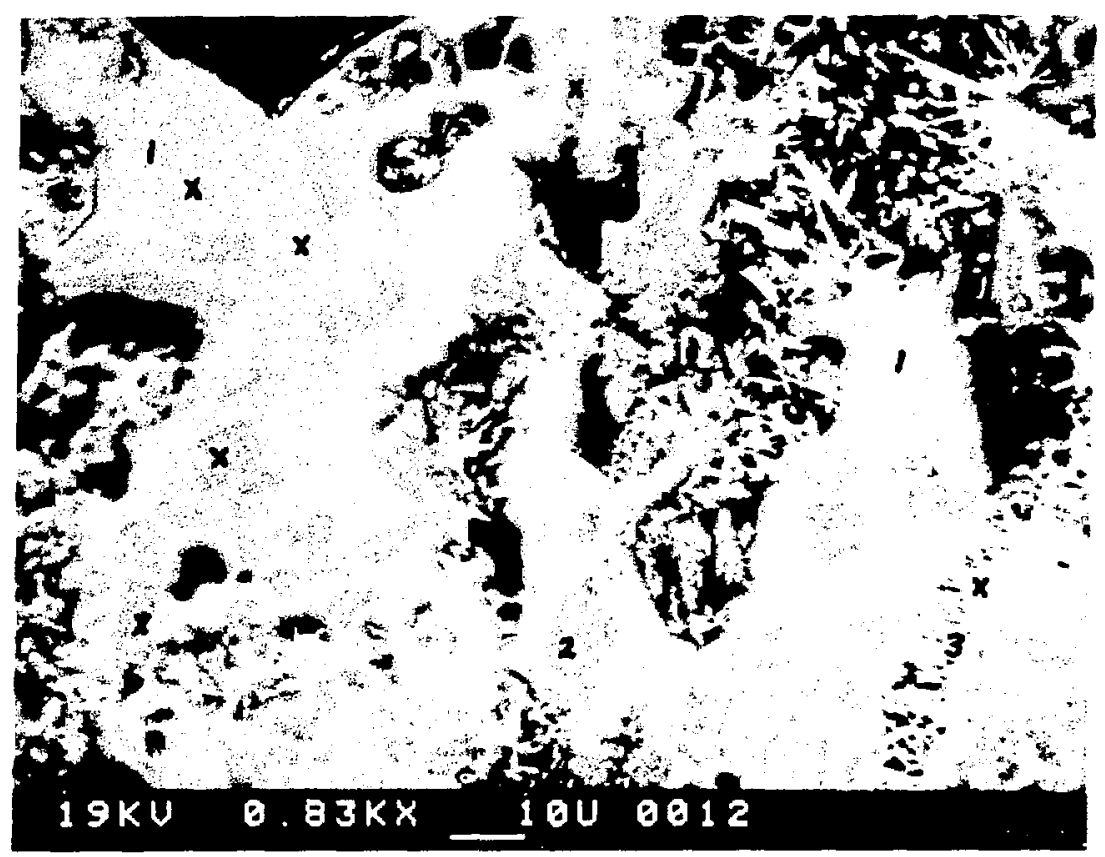

Fig. 16.

SEM BSE image of another portion of fracture at $2854 \mathrm{ft}$ showing three manganese oxide phases, labeled 1, 2, 3 for inferred order of deposition. See text for discussion. 
attempt to analyze a pyrolusite grain, but obviously includes a substantial amount of hollandite in the volume analyzed, as do the analyses marked on the SEM photograph. The variability of iron in the chemical analyses (Appendix) probably results from intergrown hollandite and hematite.

Samples at 2917 and $2923 \mathrm{ft}$ are from manganese-rich portions of iron- and manganesecoated high-angle fractures that intersect the core over several feet. SEM images of these fractures show intergrown quartz and manganese oxide on the fracture surfaces (Fig. 17). Hollandite with possible tociorokite and pyrolusite are the manganese minerals seen in the XRD pattern of the coating from $2917 \mathrm{ft}$. Two distinct phases are present in the thin section and identifiable by morphology and chemistry, and both the chemistry and the bladed appearance of one phase suggest pyrolusite rather than todorokite (Fig. 18). The phase containing Ba, believed to be hollandite, is too fine-grained to allow determination of individual crystal morphology. The high-iron analyses are of manganese oxide near but outside of the fracture trace. Chemical analyses of the manganese oxides in this sample are presented in the Appendix.

Seen in thin section, the fracture at $2923 \mathrm{ft}$ is a zone of veinlets containing manganese oxide that is intergrown slightly with matrix adjacent to the veinlets. Insufficient material was available to determine by XRD if todorokite, as well as hollandite, is present in the fracture. Chemical analyses of the manganese oxide(s) from this sample are given in the Appendix.

From about $2945 \mathrm{ft}$ to $2990 \mathrm{ft}$, the manganese oxides generally form soft black coatings up to $0.5 \mathrm{~mm}$ thick of cryptomelane/hollandite minerals and todorokite on both sub-horizontal fractures and those at about $60^{\circ}$ to horizontal. The manganese oxides are commonly intergrown with spherulites in the matrix adjacent to the fractures (Fig. 19), and with quartz on the now open surfaces of the fractures (as in the fracture at $2917 \mathrm{ft}$, Fig. 17). The manganese minerals were identified by XRD and cannot always be separated even in SEM backscattered-electron images.

Figure 20 shows the complex intergrowths of the manganese and silicate phases in the fracture at $2947 \mathrm{ft}$. Chemical analyses from three samples are given in the Appendix. Only areas that appeared to be monomineralic were analyzed. However, as todorokite was identified in the sample from $2955 \mathrm{ft}$ by XRD, but could not be identified visually either in reflected light or using the backscattered-electron image on the SEM, the chemical analyses may represent intergrowths of both minerals as well as separate phases. The sample at $2967 \mathrm{ft}$ contains a visually distinctive phase (Fig. 19) with enriched iron content and low totals. Only one analysis totalled above 85.0\%: it is included in the Appendix. The mineral appears to be partially replaced by hollandite, 


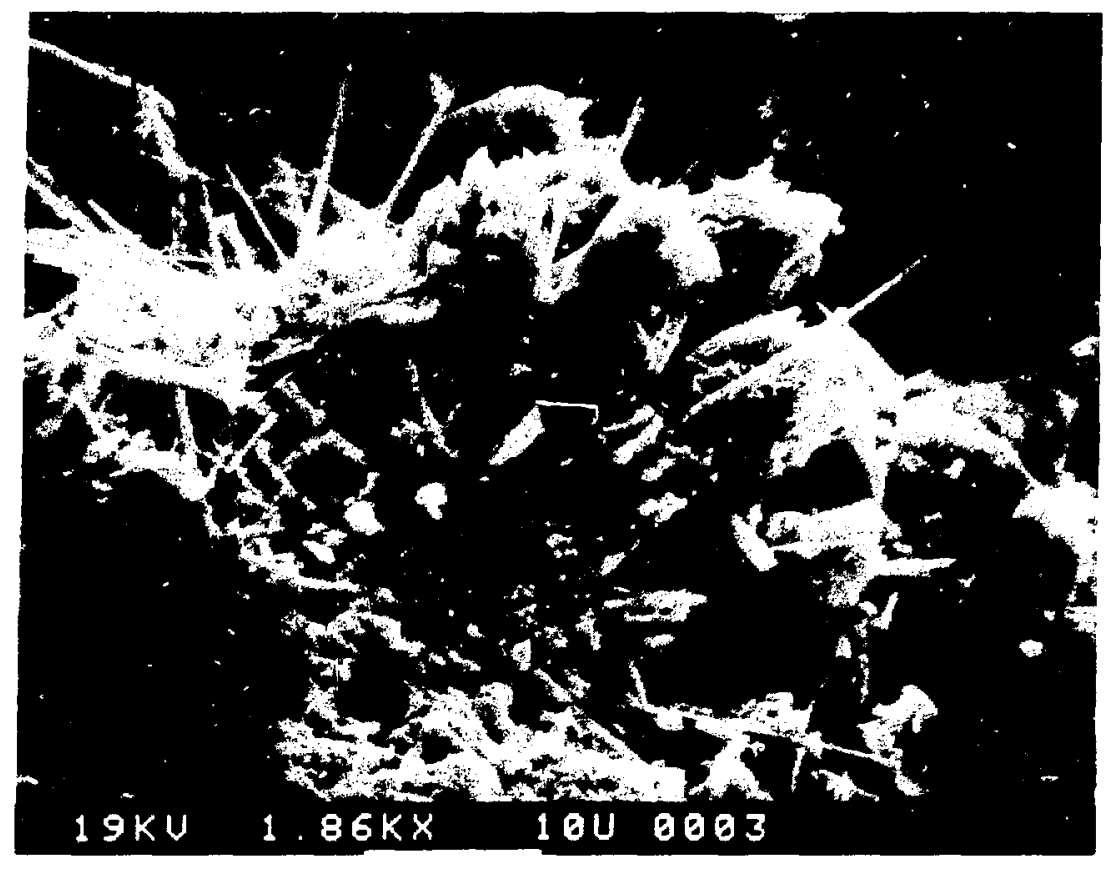

Fig. 17.

SEM image of intergrown quartz and hollandite from fracture at $2917 \mathrm{ft}$.

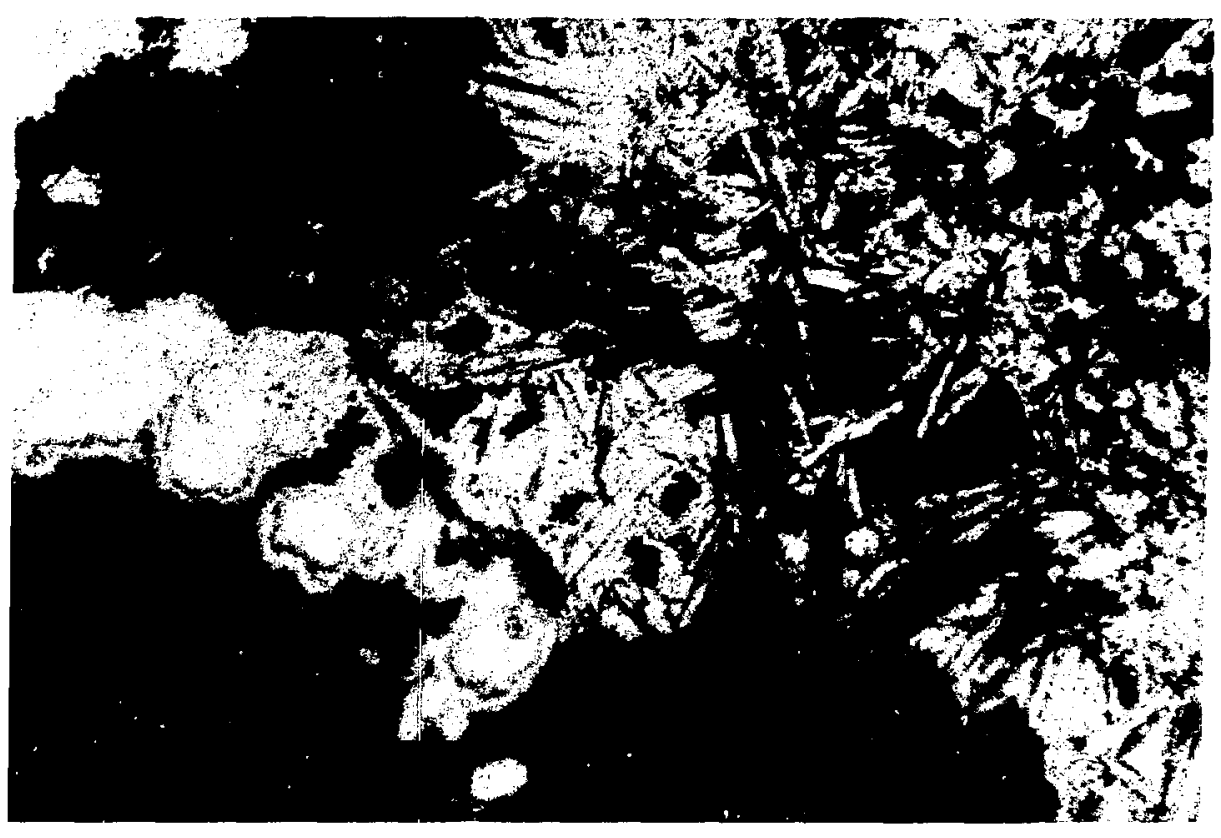

Fig. 18.

Photomicrograph of manganese "lobes" and "blades" in closed fracture from $2917 \mathrm{ft}$. Reflected light. Field of view is $0.2 \mathrm{~mm}$. 


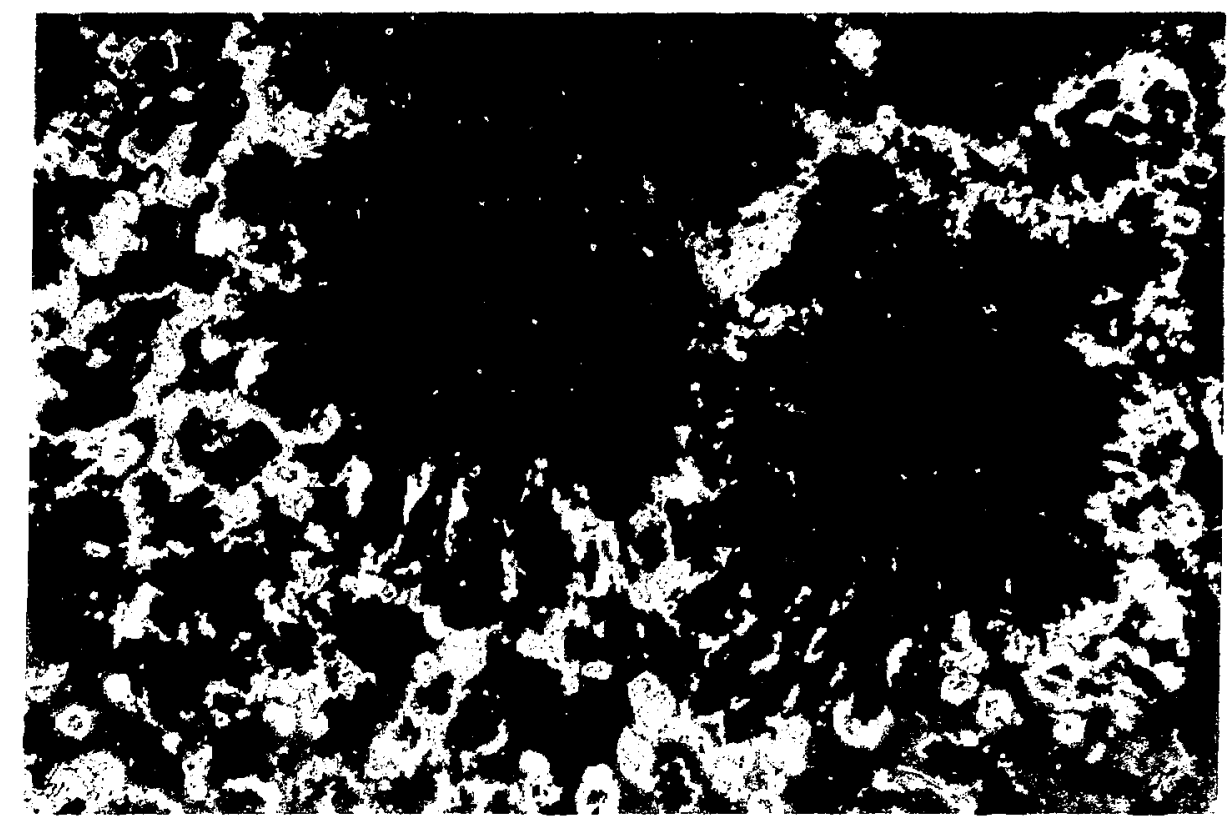

Fig. 19.

Photomicrograph of manganese oxides intergrown with spherulites in fracture at $2967 \mathrm{ft}$. Reflected light. Black is void space. Note darker angular manganese oxide phase. See text. Field of view is $1 \mathrm{~mm}$.

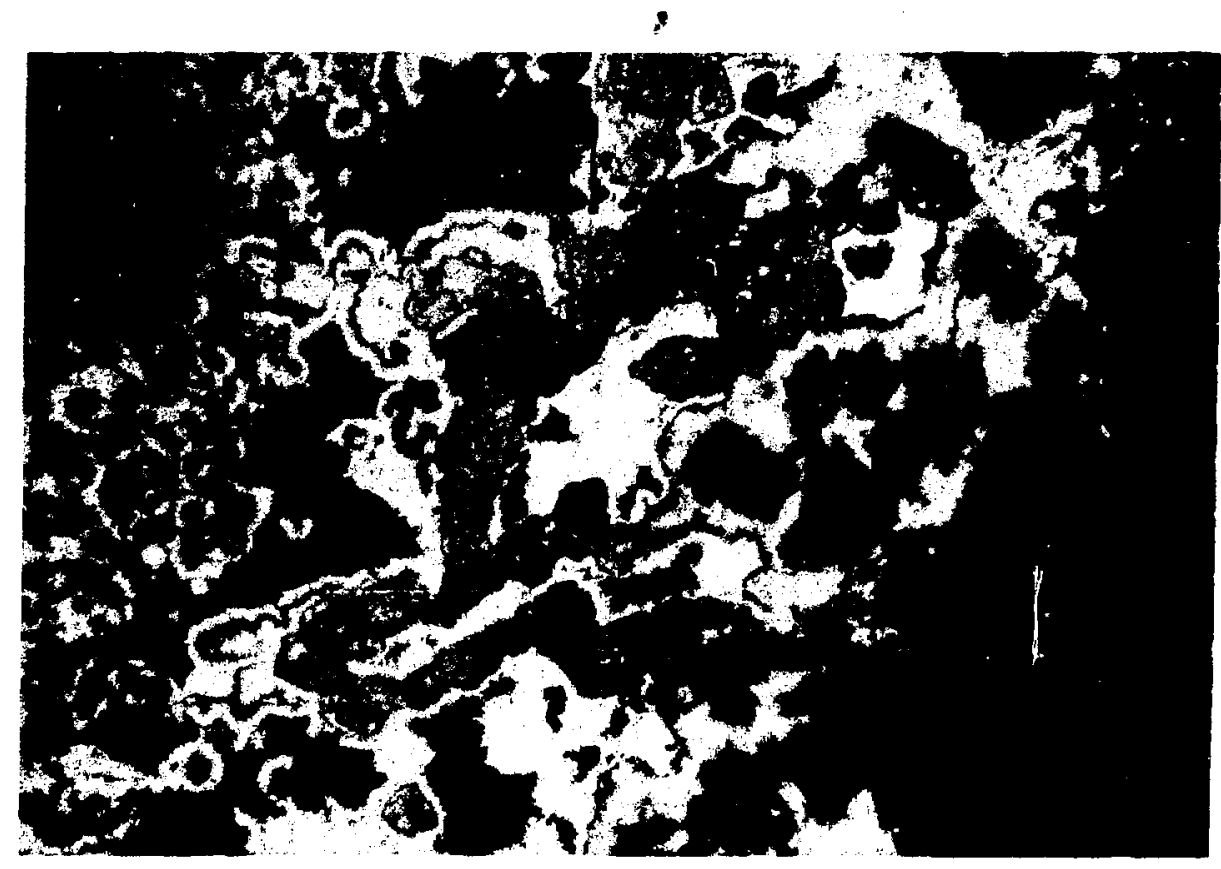

Fig. 20.

Photomicrograph of manganese oxide(s) at $2947 \mathrm{ft}$. Reflected light. Field of view is $0.5 \mathrm{~mm}$. 
but the original manganese oxide mineral is unidentified. Samples from 2947 and $2955 \mathrm{ft}$ also have some high-iron analyses on areas that appear similar in reflected light but rarely form distinct euhedral crystals in those samples.

\section{Possible Role of Manganese Oxides in Retardation}

Lobmeyer (1986) reported that $75 \%$ of the water produced from USW G-4 was from the interval 2920 to $2953 \mathrm{ft}$ and $98 \%$ of it was from below $2789 \mathrm{ft}$ (i.e., almost entirely within the Tram Member, Fig. 2). Given the common occurrence of manganese oxides as fracture-lining minerals in these intervals, this observation suggests that manganese minerals may play a role in retardation of radionuclides at Yucca Mountain. Data on redox processes at the surfaces of manganese oxides and the oxidation of other species by manganese oxides are abundant in the literature, but few authors have examined the complex manganese oxides such as hollandite, cryptomelane, coronadite, and todorokite. Murray (1975) summarized earlier literature on adsorption by manganese oxides and experimentally determined the interaction between a synthetic hydrous manganese dioxide and a number of metal ions. Murray determined the affinity of metal ions for the surface of hydrous manganese oxide to be $\mathrm{Co} \geq \mathrm{Mn}>\mathrm{Zn}>\mathrm{Ni}>\mathrm{Ba}>$ $\mathrm{Sr}>\mathrm{Ca}>\mathrm{Mg}$, and he found that adsorption of metal ions to the surfaces involved the release of a proton $\left(\mathrm{H}^{+}\right)$. Hem (1978) and Murray and Dillard (1979) demonstrated that redox processes are important at the surfaces of manganese oxides, and Murray and Dillard showed that $\mathrm{Co}^{2+}$ was oxidized to $\mathrm{Co}^{3+}$ when adsorbed on $\mathrm{MnO}_{2}$. Similarly, Bartlett (1981) showed that manganese oxides in soils can oxidize nitrite to nitrate with resultant reduction of the manganese oxides, and Oscarson et al. (1981) demonstrated that manganese oxides in freshwater lake sediments were primarily responsible for the oxidation of arsenite $\left(\mathrm{As}^{3+}\right)$ to arsenate $\left(\mathrm{As}^{5+}\right)$. In addition, McKenzie (1979) showed that adsorption of $\mathrm{Pb}, \mathrm{Cu}, \mathrm{Mn}$, or $\mathrm{Zn}$ by a synthetic manganese oxide was accompanied by a release of $\mathrm{H}^{+}$. In a study of the thermal behavior of tunnel-structure manganese oxides such as hollandite, cryptomelane, and todorokite, Bish and Post (1989) showed that these minerals were reduced and evolved oxygen upon heating to temperatures as low as $200^{\circ} \mathrm{C}$.

In a study particularly applicable to Yucca Mountain, Means et al. (1978) studied the interaction of ${ }^{60} \mathrm{Co}$ and several actinides with $\mathrm{Fe}$ and $\mathrm{Mn}$ oxides in soils and sediments at radioactive waste burial grounds at Oak Ridge National Laboratory. They found that ${ }^{60} \mathrm{Co}$, ${ }^{244} \mathrm{Cm},{ }^{241} \mathrm{Am}$, and ${ }^{238} \mathrm{Pu}$ were primarily associated with $\mathrm{Mn}$ oxides and that these radionuclides 
were not stragly sorbed by Fe oxides and organic $C$. It is noteworthy that they concluded that migration of $\mathrm{Co}$ and the actinides can be minimized by maintaining an environment in which the Mn oxides are least soluble. Although thermodynamic and solubility data are lacking for the complex $\mathrm{Mn}$ oxides, available data suggest that $\mathrm{Mn}^{4+}$ oxides are least soluble at elevated $\mathrm{pH}^{\prime} \mathrm{s}$ and under oxidizing conditions.

The ease with which these manganese oxides are reduced and the independent data demonstrating that these materials can oxidize a variety of inorganic species illustrate that these minerals are likely to interact strongly with water and dissolved or suspended species that come into contact with them. In addition, the results of Murray (1975) and McKenzie (1979) suggest that these interactions may also influence the $\mathrm{pH}$ of waters. These factors are particularly important in light of observations that waters at Yucca Mountain are oxidizing (e.g., Bish et al. 1984). It is well known that a number of radionuclides are sensitive to changes in redox conditions of waters. The actinides in particular ppear to interact strongly with Mn oxides.

\section{E. Compositional Variations of the Manganese Oxides}

Few data exist on the possible compositional variations in the tunnel-structure Mn-oxide minerals, other than approximately end-member compositions. Ostwald (1986) summarized the results of an electron-microprobe examination of todorokite samples from both terrestrial and marine occurrences. He concluded that $\mathrm{Ca}$ is present in most todorokites, and where absent, $\mathrm{Ba}$ may take its place. Examination of Ostwald's analyses reveals that most of his samples contain detectable $\mathrm{Ca}, \mathrm{Na}, \mathrm{K}, \mathrm{Mg}$, and $\mathrm{Ba}$.

To our knowledge, similar studies of the related 2-octahedra by 2-octahedra minerals such as coronadite, cryptomelane, and hollandite have not been published. Our probe data (tabulated in the Appendix) on a wide variety of tunnel-structure Mn oxides allow further generalizations to be made regarding compositional variability. The ternary plots in Fig. 21 illustrate the most significant variations in chemistry. We found no confirmed occurrences of pure hollandite-type minerals ( $2 \times 2$ octahedra) having greater than -0.05 Ca cations per formula unit ( 8 oxygens). All hollandite-type minerals appearing to contain greater amounts of $\mathrm{Ca}$ were shown by $\mathrm{X}$-ray powder diffraction to occur with todorokite, which is presumably intergrown with the hollandite. Likewise, no pure hollandite-type minerals were identified containing more than 0.1 Na per formula unit. Ba-containing hollandite-type minerals often contain significant amounts of $\mathrm{K}$, and there appears to be a complete gradation between Ba-rich hollandite and K-rich 

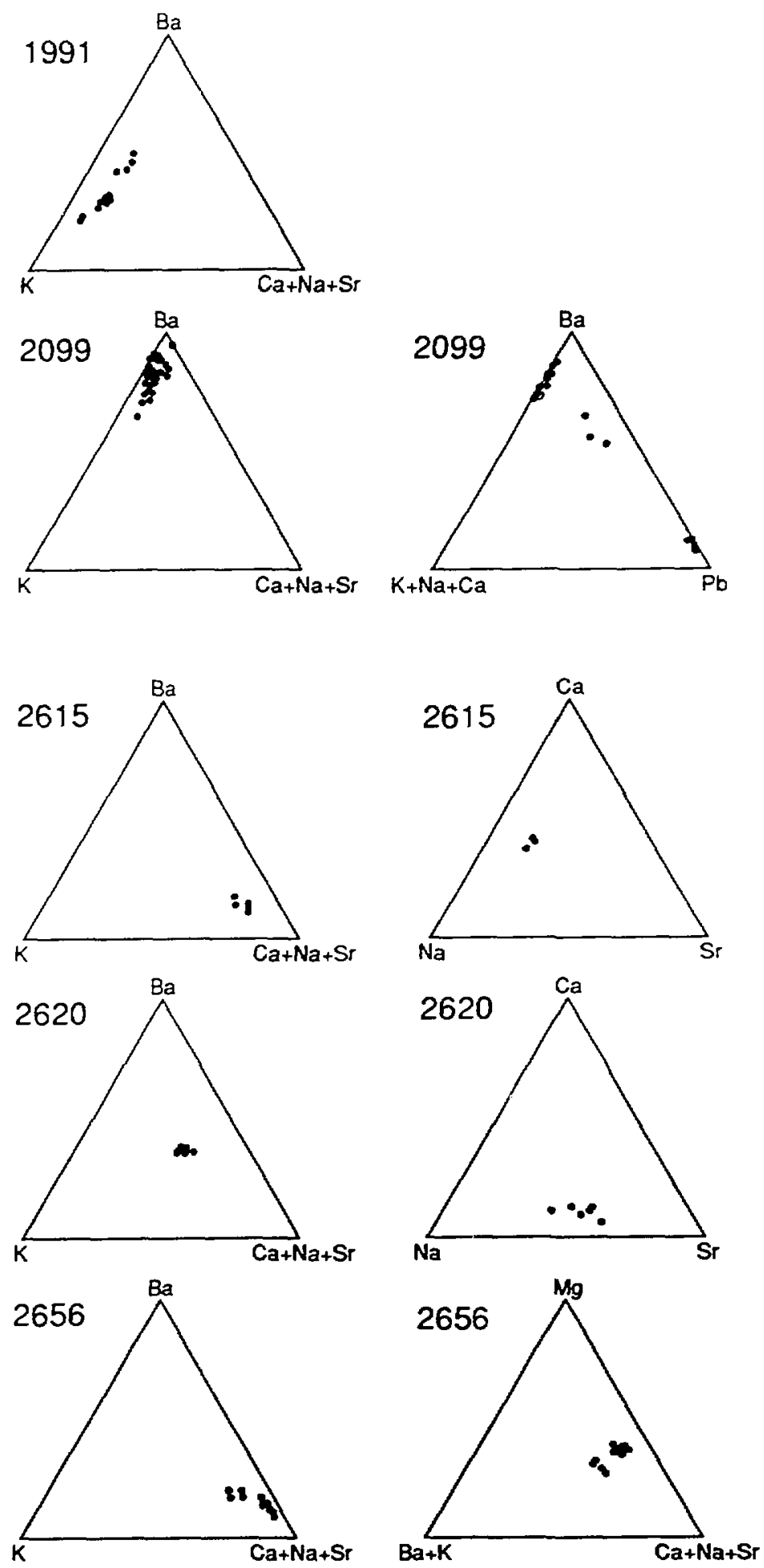

Fig 21a.

Ternary plots based on number of cations, showing chemical variability in the cryptomelanehollandite minerals in the Prow Pass and Bullfrog Members of the Crater Flat Tuff. Numbers indicate sample depth. (See Fig. 2 and Appendix.) 

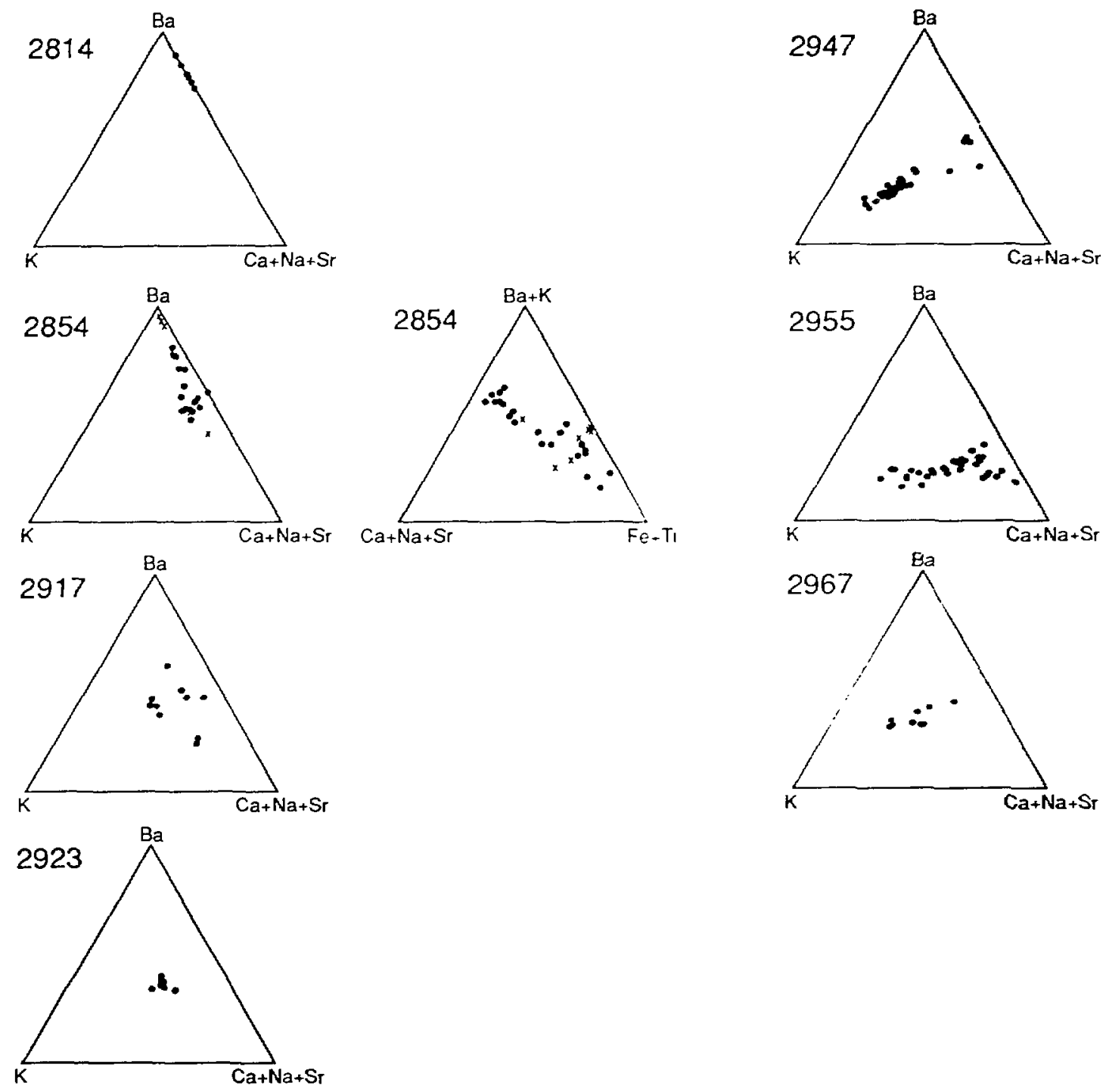

Fig. 21b.

Ternary plots based on number of cations, showing chemical variability in the manganese oxides in the Tram Member of the Crater Flat Tuff. Numbers indicate sample depth. (See Fig. 2 and Appendix.) For sample 2854, analyses designated by $x$ on Fig. 16 are also designated $x$ on these plots. 
cryptomelane (e.g., sample 1991 in Fig. 21), although most analyses are of dense portions of intergrown needles. Even the largest of the hollandite crystals are too small for zonation studies. Potassium was usually the most abundant tunnel cation other than $\mathrm{Ba}$ in Ba-rich hollandites, typically present at levels of 0.05 to $0.2 \mathrm{~K} / 8$ oxygens. Potassium is usually a minor constituent of $\mathrm{Na}$ - and Ca-rich materials.

Samples from 2814 and $2854 \mathrm{ft}$ contained relatively small amounts of tunnel cations, predominantly $\mathrm{Ba}$, suggesting that the material in these samples may be mixtures of a hollanditetype phase with a pure Mn oxide such as pyrolusite. Alternatively, these Mn oxides may be lowcharge hollandites, i.e., highly oxidized. These samples do not contain unusual amounts of $\mathrm{Fe}$, $\mathrm{Al}$, or $\mathrm{Mg}$. There is no evidence of two phases in the sample from $2814 \mathrm{ft}$, but the sample at 2854 $\mathrm{ft}$ is complex and contains three manganese phases in addition to iron oxide. Tungsten is present in analyses of the latest-formed phase in that sample. As tungsten is not easily accommodated in the hollandite structure, sub-micron intergrowths of wolframite are suspected but have not been identified on SEM images.

$\mathrm{Sr}$ is a minor constituent of most samples, although material from $2615 \mathrm{ft}$, containing significant $\mathrm{Ca}$ and $\mathrm{Na}$, is enriched in $\mathrm{Sr}(0.12-0.14 \mathrm{Sr} / 8$ oxygens). Samples from 2620, 2854, 2917, 2923, and $2955 \mathrm{ft}$, all of which are also enriched in $\mathrm{Na}$ and/or $\mathrm{Ca}$, are also slightly enriched in $\mathrm{Sr}$. $\mathrm{Mg}$ is enriched in samples from $2656 \mathrm{ft}$ and is probably associated with todorokite, although $\mathrm{x}$ ray diffraction data are unavailable to confirm the presence of todorokite. $\mathrm{Pb}$ is generally present in trace amounts, although it is the dominant tunnel cation in one phase in sample 2099 (i.e., in coronadite). The $\mathrm{Mn}$ oxide in 2099 varies from hollandite with minor $\mathrm{Pb}$ to coronadite with minor $\mathrm{Ba}$ (Fig. 21). These samples represent either a complete gradation between coronadite and hollandite or a mixture of varying proportions of coronadite and hollandite. In backscatteredelectron images at 1000 to $3000 x$ magnification, coronadite appears as remnants and/or cores within the hollandite. It is not possible to determine if zoning is present in these crystals.

\section{ORIGIN OF MANGANESE OXIDES IN FRACTURES}

Hydrothermal manganese deposits are common in volcanic rocks in the southwestern U.S., and manganese-oxide minerals are common in fractures throughout the world. Available Eh-pH diagrams suggest that precipitation of quadrivalent $M n$ oxides requires oxidizing conditions and relatively high $\mathrm{pH}$. Norman et al. (1983) discussed the origin of manganese deposits in volcanic rocks near Socorro, New Mexico. These economic deposits are similar in occurrence, mineralogy, 
and chemistry to the much smaller amounts of manganese minerals in fractures in the Crater Flat Tuff at Yucca Mountain. Norman et al. concluded from the study of fluid inclusions that the manganese oxides near Socorro were deposited by a boiling hydrothermal system at $200-375^{\circ} \mathrm{C}$. As there is no evidence of cooling by an influx of oxygenated meteoric water, they suggested that the manganese in the volcanic rocks was oxidized to the +4 state near the time of eruption and later leached from the rock matrix and deposited in fractures by a short-lived geothermal system that never came into equilibrium with the rock.

No fluid inclusion studies of samples from USW G-4 have been performed to provide temperature constraints on depositional conditions. Like the Socorro manganese deposits, the cryptomelane minerals in the Crater Flat Tuff in USW G-4 are accompanied by quartz and calcite. Calcite, when present, came after deposition of manganese and quartz. In most fractures in the Crater Flat Tuff, manganese oxides appear early in the depositional sequence. Manganese oxides are often intergrown with silica and iron oxides and with spherulites in the spherulitic devitrified tuff. Manganese-coated fractures are most abundant in the devitrified tuff intervals of the Bullfrog and Tram Members. This suggests that the mobilization and oxidation of the manganese may have taken place during devitrification. Mobilization of manganese as an incompatible element during tuff crystallization can be seen in the late-stage concentration of manganese in lithophysal (vapor phase) augite, amphibole, and biotite (Vaniman et al., 1984).

Unlike the manganese oxides in devitrified intervals, the manganese oxides in the zeolitic intervals of the Prow Pass and Tram Members appear to have been deposited after cooling and zeolitic alteration of the tuffs. In the complex fractures at $2099 \mathrm{ft}$, manganese appears to have been deposited over a long period of time, both prior to deposition of the clinoptilolite and cristobalite and either concurrent with or more probably following the deposition of clinoptilolite, but prior to deposition of mordenite. As most of the manganese oxides in the zeolitic intervals postdate the zeolitic alteration of the tuff, their deposition may be unrelated to the manganese oxides in fractures in the devitrified tuff.

Parc et al. (1989) described a mechanism of formation for a variety of manganese oxides, including cryptomelane, pyrolusite, and lithiophorite in a different environment. Their results, based on natural weathering sequences, showed that lithiophorite is a result of advanced weathering and oxidation of phases including cryptomelane. Pyrolusite also results from advanced weathering in different profiles. It is unlikely that the manganese oxides in fractures in Yucca Mountain formed through weathering, but the results of Parc et al. (1989) again 
demonstrate that the presence of these minerals is consistent with the presence of highly oxidizing fluids.

The complex mineralogy and chemistry of the manganese oxides suggest that there were several source fluids (possibly at different times) responsible for manganese deposition or that local chemistry of the tuffs strongly influenced deposition of the manganese. Whole-rock traceelement chemistry is not available for the Crater Flat Tuff in USW G-4, so a comparison between the manganese minerals in the fractures and the surrounding rock matrix cannot be made. Hollandite within clinoptilolite-lined shards in the sample at $2099 \mathrm{ft}$ contains more $\mathrm{K}$ than the hollandite filling a fracture where cristobalite rims the clinoptilolite and separates it from the hollandite. This observation suggests that the local chemical environment affects the chemistry of the manganese oxides. The origin of the manganese cannot positively be attributed to leaching of the Crater Flat Tuff, but ${ }^{87 / 86} \mathrm{Sr}$ and ${ }^{143 / 144} \mathrm{Na}$ isotope studies being performed by the U.S. Geological Survey may resolve whether the manganese was removed from the tuffs and concentrated in the fractures, or if it was leached from underlying Paleozoic carbonate rocks and deposited in the fractured tuffs by circulating fluids.

\section{CONCLUSIONS}

Manganese-oxide minerals are common in several zones of the Crater Flat Tuff. Manganese oxides are present in a few fractures in the zeolitic intervals of the Prow Pass Member; they occur in zones a few $\mathrm{cm}$ wide and contain pyrolusite and hollandite. In a fracture at $2099 \mathrm{ft}$, the mineralogy is complex and includes minor amounts of coronadite. Manganeseoxide minerals are most abundant in the devitrified intervals of the Bullfrog and Tram Members of the Crater Flat Tuff. Cryptomelane/hollandite minerals predominate, and todorokite has been identified in some samples by XRD. The manganese minerals are commonly associated with quartz, and, over a limited interval, with calcite. Where calcite occurs, it is usually the last mineral deposited in the fracture. Hematite occurs as staining and as an intergrowth with hollandite or todorokite in many fractures in the Tram Member. Manganese oxides are also found in a few fractures in the zeolitic interval of the Tram Member, occurring as purplish zones

of discoloration. Hollandite fills shards and voids in diffuse bands rather than as distinct fracture traces in the zeolitic interval. 
Chemical data suggest that there is a virtually complete chemical gradation between hollandite $(\mathrm{Ba})$ and cryptomelane $(\mathrm{K})$ and between hollandite and coronadite $(\mathrm{Pb})$. $\mathrm{Na}$ and $\mathrm{Ca}$ appear to be associated with the presence of todorokite, and $\mathrm{Sr}$ is associated with $\mathrm{Na}$ and /or $\mathrm{Ca}$.

Because of their surface properties, their ability to be easily reduced, and their occurrence along potential transport pathways, the Mn-oxide minerals in fractures at Yucca Mountain may significantly affect the retardation behavior of the geologic repository. These minerals are particularly important for radionuclides such as the actinides that do not strongly interact with smectites and zeolites but are sensitive to redox conditions. In addition, these minerals have the potential to affect the oxidation potential of the groundwaters contacting them.

\section{ACKNOWLEDGMENTS}

The authors thank M. Ebinger and D. Vaniman for their review comments and suggestions for improvement of this paper. This work was supported by the U.S. Department of Energy, Yucca Mountain Project.

\section{REFERENCES}

Bartlett, R. J. (1981) Nonmicrobial Nitrite-to-Nitrate Transformation in Soils. Soil Sci. Soc. Am. J., 45, 1054-1058. NNA.890918.0506

Bence, A. E., and Albee, A. L. (1968) Empirical Correction Factors for Electron Microanalysis of Silicates and Oxides. J. Geol. 76, 382-403. NNA.890918.0509

Bish, D. L., Ogard, A. E., Vaniman, D. T., and Benson, L. (1984) Mineralogy-Petrology and Groundwater Geochemistry of Yucca Mountain Tuffs. in Scientific Basis for Nuclear Waste Management VII, Materials Research Society Symposia Proceedings, Boston, Massachusetts (G. L. McVay Ed.) 283-291. NNA.870406.0085

Bish, D. L. and Post, J. E. (1989) Thermal Behavior of Complex, Tunnel-Structure Manganese Oxides. Amer. Mineral. 74, 177-186. NNA.890602.0028

Carlos, B. A. (1985) Minerals in Fractures of the Unsaturated Zone from Drill Core USW G-4, Yucca Mountain, Nye County, Nevada. Los Alamos National Laboratory report LA-10415MS. HQS.880517.1112

Carlos, B. A. (1986) Occurrence of Fracture-Lining Manganese Minerals in Silicic Tuffs, Yucca Mountain, Nevada, USA. Proceedings WRI-5. NNA.890918.0507

Carlos, B. A. (1987) Minerals in Fractures of the Saturated Zone from Drill Core USW G-4, Yucca Mountain, Nye County, Nevada. Los Alamos National Laboratory report LA-10927-MS. NNA.870708.0026 
Frenzel, G. (1976) The Manganese Ore Minerals. in Geology and Geochemistry of Manganese, v. I, (I. M. Varentsov and Gy. Grasselly, ed). NNA.890918.0542

Hem, J. D. (1978) Redox Processes at Surfaces of Manganese Oxide and Their Effects on Aqueous Metal Ions. Chem. Geol. 21, 199-218. NNA.890918.0508

Lobmeyer, D. H. (1986) Geohydrology of Rocks Penetrated by Test Well USW G-4, Yucca Mountain, Nye County, Nevada. U.S. Geol. Survey Water-Res. Inv. Rept. 86-4015. 38 p. NNA.890918.0510

Manceau, A., (1988) Personal Communication to Dave Bish, Los Alamos National Laboratory, regarding manganese oxides. Dated October 3, 1988.

Manceau, A. and Combes, J. M. (1988) Structure of $\mathrm{Mn}$ and Fe Oxides and Oxyhydroxides: A Topological Approach by EXAFS. Phys. Chem. Minerals 15, 283-295. NNA.890918.0511

Means, J. L., Crerar, D. A., Borcsik, M. P., and Duguid, J. O. (1978) Adsorption of Co and Selected ictinides by $\mathrm{Mn}$ and $\mathrm{Fe}$ Oxides in Soils and Sediments. Geochim. Cosmochim. Acta 42, 17631773. NNA.890918.0512

McKenzie, R. M. (1979) Proton Release During Adsorption of Heavy Metal Ions by a Hydrous Manganese Dioxide. Geochim. Cosmochim. Acta 43, 1855-1857. NNA.890918.0513

Murray, J. W. (1975) The Interaction of Metal Ions at the Manganese Dioxide-Solution Interface. Geochim. Cosmochim. Acta 39, 505-519. NNA.890918.0514

Murray, J. W. and Dillard, J. G. (1979) The Oxidation of Cobalt(II) Adsorbed on Manganese Dioxide. Geochim. Cosmochim. Acta 43, 781-787. NNA.890918.0515

Norman, D. I., Bazrafshan, K., and Eggleston, T. L. (1983) Mineralization of the Luis Lopez Epithermal Manganese Deposits in Light of Fluid Inclusion and Geologic Studies. New Mexico Geological Society Guidebook, 247-251. NNA.890918.0546

Oscarson, D. W., Huang, P. M., and Liaw, W. K. (1981) Role of Manganese in the Oxidation of Arsenite by Freshwater Lake Sediments. Clays and Clay Minerals 29, 219-225. NNA.890918.0516

Ostwald, J. (1986) Some Observations on the Chemical Composition of Todorokite. Min. Mag. 50, 336-340. NNA.890918.0517

Parc, S., Nahon, D., Tardy, Y., and Vieillard, P. (1989) Estimated Solubility Products and Fields of Stability for Cryptomelane, Nsutite, Birnessite, and Lithiophorite Based on Natural Lateritic Weathering Sequences. Amer. Mineral. 74, 466-475. NNA.890918.0518

Post, J. E. and Bish, D. L. (1988) Rietveld Refinement of the Todorokite Structure. Amer. Mineral. 73, 861-869. NNA.890918.0519 
Spengler, R. W. and Chornack, M. P. (1984) Stratigraphic and Structural Characteristics of Volcanic Rocks in Core Hole USW G-4, Yucca Mountain, Nye County, Nevada, Section of Geophysical Logs by D. C. Muller and J. E. Kibler. U.S. Geol. Survey Open-file report 84-789. NNA.870325.0101

Vaniman, D., Bish, D., Broxton, D., Byers, F., Heiken, G., Carlos, B., Semarge, E., Caporuscio, F., and Gooley, R. (1984) Variations in Authigenic Mineralogy and Sorptive Zeolite Abundance at Yucca Mountain Nevada, Based on Studies of Drill Cores USW GU-3 and G-3. Los Alamos National Laboratory Report LA-9707-MS. HQS.880517.1542 
APPENDIX

TABLES OF ELECTRON MICROPROBE ANALYSES 


\begin{tabular}{lccc} 
& \multicolumn{3}{c}{ Pyrolusite } \\
\cline { 2 - 4 } $\mathrm{SiO}_{2}$ & 1.82 & 2.62 & 1.69 \\
$\mathrm{TiO}_{2}$ & - & - & 0.22 \\
$\mathrm{MnO}_{2}$ & 86.56 & 85.42 & 91.78 \\
$\mathrm{CeO}_{2}$ & 0.15 & 0.14 & 0.16 \\
$\mathrm{Al}_{2} \mathrm{O}_{3}$ & 2.72 & 2.80 & 1.87 \\
$\mathrm{Fe}_{2} \mathrm{O}_{3}$ & 0.21 & 0.17 & 0.60 \\
$\mathrm{MgO}$ & - & - & - \\
$\mathrm{CaO}$ & 0.11 & 0.13 & 0.11 \\
$\mathrm{SrO}$ & - & - & - \\
$\mathrm{BaO}$ & - & - & - \\
$\mathrm{Na}_{2} \mathrm{O}$ & - & - & 0.11 \\
$\mathrm{~K}_{2} \mathrm{O}$ & 0.05 & 0.05 & 0.06 \\
$\mathrm{Total}$ & 91.62 & 91.33 & 96.60 \\
$\mathrm{Si}^{+4}$ & & & \\
$\mathrm{Ti}^{+4}$ & 0.23 & 0.33 & 0.20 \\
$\mathrm{Mn}^{+4}$ & - & - & 0.02 \\
$\mathrm{Ce}$ & 7.44 & 7.34 & 7.52 \\
$\mathrm{Al}^{+3}$ & 0.01 & 0.01 & 0.01 \\
$\mathrm{Fe}^{+3}$ & 0.40 & 0.41 & 0.26 \\
$\mathrm{Ca}$ & 0.02 & 0.02 & 0.05 \\
$\mathrm{Sr}^{+2}$ & 0.01 & 0.02 & 0.01 \\
$\mathrm{Ba}^{+2}$ & - & - & - \\
$\mathrm{Na}^{+1}$ & - & - & - \\
$\mathrm{K}^{+1}$ & - & - & 0.03 \\
$\mathrm{Total}_{\mathrm{O}}^{+2}$ & 0.01 & 0.01 & 0.01 \\
$\mathrm{O}^{-2}$ & 8.12 & 8.12 & 8.11 \\
& 16.00 & 16.00 & 16.00
\end{tabular}

Cryptomelane-Hollandite

\begin{tabular}{ccccccc}
\hline 0.25 & 0.44 & 0.24 & 0.26 & 0.58 & 0.20 & 0.56 \\
- & 0.11 & - & - & - & - & - \\
88.60 & 86.64 & 87.13 & 83.43 & 82.02 & 85.66 & 83.85 \\
- & - & - & $n / a$ & - & $n / a$ & $n / a$ \\
0.45 & 0.44 & 0.46 & 0.78 & 0.57 & 0.48 & 0.75 \\
0.89 & 0.69 & 0.83 & 0.74 & 0.72 & 0.73 & 1.31 \\
- & - & - & - & - & - & - \\
0.09 & 0.09 & 0.11 & 0.22 & 0.25 & 0.24 & 0.23 \\
- & - & 0.19 & 0.09 & 0.12 & 0.07 & - \\
4.89 & 5.02 & 5.05 & 5.61 & 5.74 & 5.84 & 5.95 \\
0.31 & 0.29 & 0.23 & 0.36 & 0.35 & 0.31 & 0.36 \\
4.74 & 4.83 & 4.65 & 3.34 & 3.19 & 3.88 & 3.86 \\
100.22 & 98.55 & 98.89 & 94.83 & 93.54 & 97.41 & 96.87 \\
& & & & & & \\
0.03 & 0.06 & 0.03 & 0.03 & 0.08 & 0.03 & 0.07 \\
- & 0.01 & - & - & - & - & - \\
7.53 & 7.50 & 7.52 & 7.50 & 7.48 & 7.53 & 7.40 \\
- & - & - & $\mathrm{n} / \mathrm{a}$ & - & $\mathrm{n} / \mathrm{a}$ & $\mathrm{n} / \mathrm{a}$ \\
0.07 & 0.06 & 0.07 & 0.12 & 0.09 & 0.07 & 0.11 \\
0.08 & 0.07 & 0.08 & 0.07 & 0.07 & 0.07 & 0.13 \\
0.01 & 0.01 & 0.01 & 0.03 & 0.04 & 0.03 & 0.03 \\
- & - & 0.01 & 0.01 & 0.01 & 0.01 & - \\
0.24 & 0.25 & 0.25 & 0.29 & 0.30 & 0.29 & 0.30 \\
0.07 & 0.07 & 0.06 & 0.09 & 0.09 & 0.08 & 0.09 \\
0.74 & 0.77 & 0.74 & 0.55 & 0.54 & 0.63 & 0.63 \\
8.77 & 8.79 & 8.77 & 8.69 & 8.68 & 8.73 & 8.76 \\
16.00 & 16.00 & 16.00 & 16.00 & 16.00 & 16.00 & 16.00 \\
& & & & & &
\end{tabular}

Ana!yzed but not detected: $\mathrm{Co}, \mathrm{Ni}, \mathrm{Cu}, \mathrm{Zn}, \mathrm{Pb}, \mathrm{P}, \mathrm{La}, \mathrm{Y}, \mathrm{Cl}$ 
MANGANESE OXIDES USW G-4 1990-1991 FT (cont.)

Cryptomelane-Hollandite

\begin{tabular}{|c|c|c|c|c|c|c|c|c|c|}
\hline $\mathrm{SiO}_{2}$ & 0.16 & 0.68 & 0.24 & 0.26 & 0.19 & 0.27 & 0.55 & 0.29 & 0.26 \\
\hline $\mathrm{TiO}_{2}$ & - & - & $\sim$ & - & - & - & - & 0.11 & - \\
\hline $\mathrm{MnO}_{2}$ & 86.67 & 82.52 & 85.90 & 83.23 & 86.94 & 83.83 & 84.12 & 83.68 & 84.54 \\
\hline $\mathrm{CeO}_{2}{ }^{2}$ & - & $\mathbf{n} / \mathbf{a}$ & $\mathbf{n} / \mathbf{a}$ & $\mathbf{n} / \mathbf{a}$ & $\mathbf{n} / \mathbf{a}$ & n/a & - & $\mathbf{n} / \mathbf{a}$ & - \\
\hline $\mathrm{Al}_{2} \mathrm{O}_{3}$ & 0.54 & 0.56 & 0.62 & 0.52 & 0.62 & 0.43 & 0.34 & 0.53 & 0.42 \\
\hline $\mathrm{Fe}_{2} \mathrm{O}_{3}$ & 0.69 & 0.83 & 0.94 & 0.65 & 0.52 & 0.91 & 1.03 & 0.65 & 0.61 \\
\hline $\mathrm{MgO}^{\mathrm{J}}$ & - & - & - & - & - & - & - & - & - \\
\hline $\mathrm{CaO}$ & 0.23 & 0.24 & 0.24 & 0.23 & 0.19 & 0.21 & 0.14 & 0.26 & 0.22 \\
\hline SrO & 0.07 & 0.10 & 0.07 & 0.07 & 0.07 & 0.06 & - & 0.05 & 0.07 \\
\hline $\mathrm{BaO}$ & 6.03 & 6.09 & 6.31 & 6.31 & 6.55 & 8.32 & 8.62 & 9.02 & 9.23 \\
\hline $\mathrm{Na}_{2} \mathrm{O}$ & 0.37 & 0.40 & 0.41 & 0.36 & 0.40 & 0.37 & 0.33 & 0.37 & 0.32 \\
\hline $\mathrm{K}_{2} \mathrm{O}$ & 4.13 & 3.23 & 3.63 & 3.57 & 3.61 & 2.52 & 2.91 & 2.34 & 2.13 \\
\hline Total & 98.89 & 94.65 & 98.36 & 95.20 & 99.09 & 96.92 & 98.04 & 97.30 & 97.80 \\
\hline $\mathrm{Si}^{+4}$ & 0.02 & 0.09 & 0.03 & 0.03 & 0.02 & 0.03 & 0.07 & 0.04 & 0.03 \\
\hline $\mathrm{Ti}^{+4}$ & - & - & - & - & - & - & - & 0.01 & - \\
\hline $\mathrm{Mn}^{+4}$ & 7.52 & 7.45 & 7.49 & 7.51 & 7.53 & 7.49 & 7.45 & 7.48 & 7.52 \\
\hline $\mathrm{Ce}^{+4}$ & - & n/a & $\mathrm{n} / \mathrm{a}$ & $\mathrm{n} / \mathbf{a}$ & $\mathrm{n} / \mathrm{a}$ & $\mathrm{n} / \mathrm{a}$ & - & $\mathrm{n} / \mathbf{a}$ & - \\
\hline $\mathrm{Al}^{+3}$ & 0.08 & 0.09 & 0.09 & 0.08 & 0.09 & 0.07 & 0.05 & 0.08 & 0.06 \\
\hline $\mathrm{Fe}^{+3}$ & 0.07 & 0.08 & 0.09 & 0.06 & 0.05 & 0.09 & 0.10 & 0.06 & 0.06 \\
\hline $\mathrm{Ca}^{+2}$ & 0.03 & 0.03 & 0.03 & 0.03 & 0.03 & 0.03 & 0.02 & 0.04 & 0.03 \\
\hline $\mathrm{Sr}^{+2}$ & 0.01 & 0.01 & 0.01 & 0.01 & 0.01 & 0.00 & - & 0.00 & 0.01 \\
\hline $\mathrm{Ba}+2$ & 0.30 & 0.31 & 0.31 & 0.32 & 0.32 & 0.42 & 0.43 & 0.46 & 0.47 \\
\hline $\mathrm{Na}^{+1}$ & 0.09 & 0.10 & 0.10 & 0.09 & 0.10 & 0.09 & 0.08 & 0.09 & 0.08 \\
\hline $\mathrm{K}^{+1}$ & 0.66 & 0.54 & 0.58 & 0.59 & 0.58 & 0.42 & 0.48 & 0.39 & 0.35 \\
\hline Total & 8.77 & 8.70 & 8.73 & 8.73 & 8.72 & 8.65 & 8.68 & 8.64 & 8.60 \\
\hline $\mathrm{O}^{-2}$ & 16.00 & 16.00 & 16.00 & 16.00 & 16.00 & 16.00 & 16.00 & 16.00 & 16.00 \\
\hline
\end{tabular}

Analyzed but not detected: $\mathrm{Co}, \mathrm{Ni}, \mathrm{Cu}, \mathrm{Zn}, \mathrm{Pb}, \mathrm{P}, \mathrm{La}, \mathrm{Y}, \mathrm{C}$ 


\begin{tabular}{lcccc} 
& \multicolumn{4}{c}{ Iron Oxides } \\
\cline { 2 - 5 } $\mathrm{SiO}_{2}$ & 9.01 & 8.37 & 8.95 & 5.52 \\
$\mathrm{TiO}_{2}$ & - & - & - & - \\
$\mathrm{MnO}_{2}$ & 2.02 & 2.29 & 2.31 & 1.93 \\
$\mathrm{CeO}_{2}$ & 0.10 & - & - & - \\
$\mathrm{Al}_{2} \mathrm{O}_{3}$ & 0.87 & 0.85 & 0.95 & 0.62 \\
$\mathrm{Fe}_{2} \mathrm{O}_{3}$ & 73.60 & 73.33 & 74.03 & 84.10 \\
$\mathrm{MgO}$ & - & - & 0.05 & - \\
$\mathrm{CaO}$ & 0.16 & 0.09 & 0.11 & 0.25 \\
$\mathrm{NiO}$ & 0.12 & - & - & - \\
$\mathrm{ZnO}$ & - & - & - & - \\
$\mathrm{SrO}$ & - & - & - & - \\
$\mathrm{BaO}$ & - & - & 0.20 & - \\
$\mathrm{PbO}$ & 0.30 & 0.39 & 0.27 & $n / a$ \\
$\mathrm{Na}$ & - & - & - & - \\
$\mathrm{K}_{2} \mathrm{O}$ & - & - & 0.07 & 0.06 \\
$\mathrm{Total}^{2}$ & 86.18 & 85.32 & 86.94 & 92.48 \\
$\mathrm{Si}^{+4}$ & & & & \\
$\mathrm{Ti}^{+4}$ & 1.36 & 1.28 & 1.34 & 0.80 \\
$\mathrm{Mn}^{+4}$ & - & - & - & - \\
$\mathrm{Ce}$ & 0.21 & 0.24 & 0.24 & 0.19 \\
$\mathrm{Al}^{+3}$ & 0.01 & - & - & - \\
$\mathrm{Fe}^{+3}$ & 0.15 & 0.15 & 0.17 & 0.11 \\
$\mathrm{Mg}^{+2}$ & 8.37 & 8.46 & 8.35 & 9.20 \\
$\mathrm{Ca}$ & - & - & 0.01 & - \\
$\mathrm{Ni}^{+2}$ & 0.03 & 0.01 & 0.02 & 0.04 \\
$\mathrm{Zn}^{+2}$ & 0.01 & - & - & - \\
$\mathrm{Sr}^{+2}$ & - & - & - & - \\
$\mathrm{Ba}^{+2}$ & - & - & - & - \\
$\mathrm{Pb}^{+2}$ & - & - & 0.01 & - \\
$\mathrm{Na}^{+1}$ & 0.01 & 0.02 & 0.01 & $\mathbf{n} / \mathrm{a}$ \\
$\mathrm{K}^{+1}$ & - & - & - & - \\
$\mathrm{Total}^{+1}$ & - & - & 0.01 & 0.01 \\
$\mathrm{O}^{-2}$ & 10.16 & 10.17 & 10.17 & 10.35 \\
& 16.00 & 16.00 & 16.00 & 16.00 \\
$\mathrm{An}^{+2}$ & & & &
\end{tabular}

\begin{tabular}{ccccc}
\multicolumn{5}{c}{ Pyrolusite } \\
\hline & & & & \\
1.61 & 0.71 & 0.83 & 0.85 & 0.77 \\
- & 0.24 & - & - & - \\
86.27 & 92.32 & 91.07 & 90.14 & 93.90 \\
0.12 & 0.20 & 0.21 & 0.26 & - \\
1.36 & 0.94 & 1.49 & 1.08 & 1.19 \\
2.98 & 2.15 & 3.00 & 1.17 & 2.24 \\
- & - & - & - & - \\
0.07 & 0.07 & 0.07 & 0.05 & 0.09 \\
- & - & 0.12 & - & - \\
0.21 & - & - & 0.16 & - \\
- & - & - & - & - \\
- & 0.22 & 0.40 & 0.43 & 1.20 \\
- & - & - & - & 0.48 \\
- & - & - & - & - \\
- & - & - & - & 0.10 \\
92.62 & 96.85 & 97.19 & 94.14 & 99.97 \\
& & & & \\
0.20 & 0.08 & 0.10 & 0.10 & 0.09 \\
- & 0.02 & - & - & - \\
7.42 & 7.63 & 7.51 & 7.66 & 7.59 \\
0.01 & 0.01 & 0.01 & 0.01 & - \\
0.20 & 0.13 & 0.21 & 0.16 & 0.16 \\
0.28 & 0.19 & 0.27 & 0.11 & 0.20 \\
- & - & - & - & - \\
0.01 & 0.01 & 0.01 & 0.01 & 0.01 \\
- & - & 0.01 & - & - \\
0.02 & - & - & 0.01 & - \\
- & - & - & - & - \\
- & 0.01 & 0.02 & 0.02 & 0.06 \\
- & - & - & - & 0.02 \\
- & - & - & - & - \\
- & - & - & - & 0.01 \\
8.13 & 8.09 & 8.14 & 8.09 & 8.14 \\
16.00 & 16.00 & 16.00 & 16.00 & 16.00
\end{tabular}

Analyzed but not detected: $\mathrm{Cu}, \mathrm{La}, \mathrm{Y}, \mathrm{Cl}$ 
MANGANESE AND IRON OXIDES FROM 2099-2100 FT (cont)

Coronadite

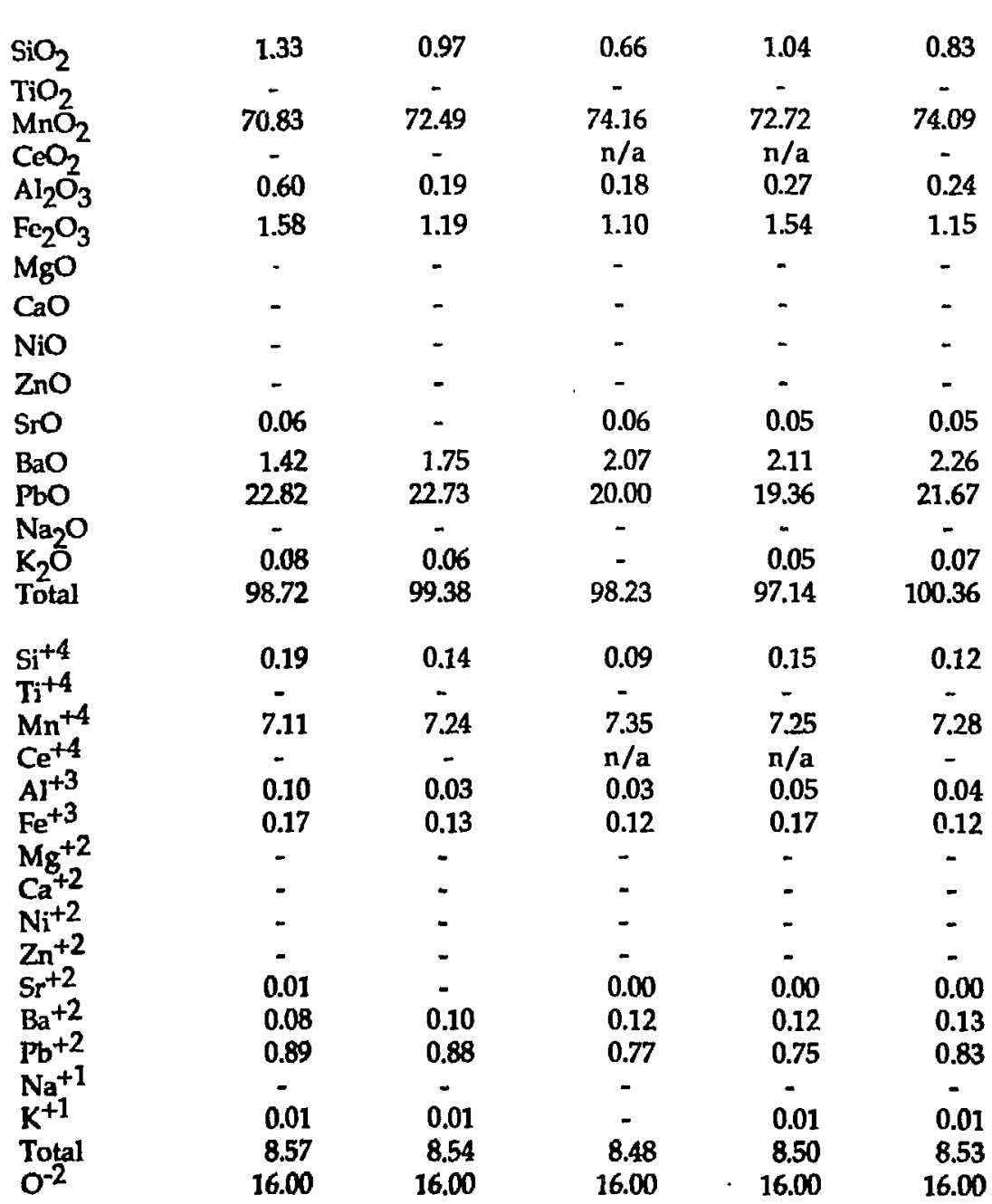

Pb-Hollandite

\begin{tabular}{|c|c|c|c|c|}
\hline 0.71 & 0.38 & 0.30 & 0.34 & 0.47 \\
\hline - & - & - & - & - \\
\hline 78.92 & 74.14 & 77.95 & 78.13 & 78.98 \\
\hline$*$ & $\mathrm{n} / \mathrm{a}$ & $\mathrm{n} / \mathrm{a}$ & - & $*$ \\
\hline 0.15 & 0.39 & 0.36 & 0.46 & 0.28 \\
\hline 1.81 & 1.29 & 0.74 & 1.49 & 1.45 \\
\hline- & - & - & - & 0.24 \\
\hline 0.07 & - & 0.05 & - & 0.08 \\
\hline 0.22 & - & 0.11 & - & 0.20 \\
\hline 0.28 & 0.23 & - & - & - \\
\hline 0.29 & 0.08 & - & - & 0.23 \\
\hline 9.62 & 9.98 & 10.38 & 11.65 & 11.99 \\
\hline$n / a$ & 9.64 & 7.53 & 5.88 & $\mathrm{n} / \mathrm{a}$ \\
\hline 0.10 & 0.14 & 0.16 & 0.08 & 0.16 \\
\hline 0.31 & 0.42 & 0.59 & 0.59 & 0.39 \\
\hline 92.48 & 96.69 & 98.17 & 98.62 & 94.47 \\
\hline 0.10 & 0.05 & 0.04 & 0.05 & 0.06 \\
\hline - & - & - & - & - \\
\hline 7.43 & 7.29 & 7.39 & 7.34 & 7.40 \\
\hline- & $\mathrm{n} / \mathrm{a}$ & $\mathrm{n} / \mathrm{a}$ & - & - \\
\hline 0.02 & 0.07 & 0.06 & 0.07 & 0.04 \\
\hline 0.19 & 0.14 & 0.08 & 0.15 & 0.15 \\
\hline- & - & - & - & 0.05 \\
\hline 0.01 & - & 0.01 & - & 0.01 \\
\hline 0.02 & - & 0.01 & - & 0.02 \\
\hline 0.03 & 0.02 & - & - & - \\
\hline 0.02 & 0.01 & - & - & 0.02 \\
\hline 0.51 & 0.56 & 0.56 & 0.62 & 0.64 \\
\hline- & 0.37 & 0.28 & 0.22 & - \\
\hline 0.03 & 0.04 & 0.04 & 0.02 & 0.04 \\
\hline 0.05 & 0.08 & 0.10 & 0.10 & 0.07 \\
\hline 8.41 & 8.61 & 8.57 & 8.57 & 8.50 \\
\hline 16.00 & 16,00 & 16.00 & 16.00 & 16.00 \\
\hline
\end{tabular}


Hollandite

\begin{tabular}{|c|c|c|c|c|c|c|c|c|c|c|}
\hline $\mathrm{SiO}_{2}$ & $\begin{array}{l}0.35 \\
0.13\end{array}$ & $\begin{array}{l}0.89 \\
0.10\end{array}$ & 0.89 & $\begin{array}{l}0.14 \\
0.08\end{array}$ & $\begin{array}{l}0.14 \\
0.07\end{array}$ & 0.26 & 0.30 & 0.09 & 0.16 & 0.43 \\
\hline $\mathrm{TiO}_{2}^{-}$ & 0.13 & $\begin{array}{r}0.10 \\
7054\end{array}$ & & $\begin{array}{r}0.08 \\
0100\end{array}$ & 0.07 & & - & - & - & 0.15 \\
\hline $\mathrm{MnO}_{2}$ & 78.11 & 70.54 & 72.28 & 81.80 & 80.84 & 81.48 & 76.16 & 81.22 & 81.78 & 74.46 \\
\hline $\mathrm{CeO}_{2}^{2}$ & $*$ & • & $"$ & $\mathbf{n} / \mathbf{a}$ & $\mathbf{n} / \mathbf{a}$ & $\mathbf{n} / \mathbf{a}$ & • & - & $\mathbf{n} / \mathbf{a}$ & $*$ \\
\hline $\mathrm{Al}_{2} \mathrm{O}_{3}$ & 0.42 & 0.78 & 0.63 & 0.44 & 0.39 & 0.32 & 0.49 & 0.42 & 0.49 & 0.53 \\
\hline $\mathrm{Fe}_{2}^{2} \mathrm{O}_{3}$ & 1.24 & 2.41 & 2.52 & 0.59 & 0.88 & 1.50 & 1.03 & 0.60 & 0.66 & 1.18 \\
\hline $\mathrm{MgO}^{\circ}$ & - & 0.06 & - & - & - & - & - & - & - & 0.30 \\
\hline $\mathrm{CaO}$ & 0.15 & 0.08 & 0.07 & 0.11 & 0.07 & - & 0.15 & 0.09 & 0.10 & 0.16 \\
\hline NiO & - & - & - & - & - & - & 0.14 & - & - & - \\
\hline $\mathrm{ZnO}$ & - & - & - & - & 0.11 & - & - & - & - & - \\
\hline SrO & - & - & - & - & - & - & - & - & - & - \\
\hline $\mathrm{BaO}$ & 12.07 & 12.19 & 12.29 & 12.50 & 12.58 & 12.79 & 1280 & 12.94 & 13.02 & 13.04 \\
\hline PbO & $\mathbf{n} / \mathbf{a}$ & $\mathbf{n} / \mathbf{a}$ & $\mathbf{n} / \mathbf{a}$ & 0.47 & 0.57 & 0.29 & $\mathbf{n} / \mathbf{a}$ & 0.43 & 0.51 & $\mathbf{n} / \mathbf{a}$ \\
\hline $\mathrm{Na}$, O & 0.13 & 0.10 & - & 0.12 & 0.19 & - & 0.21 & 0.13 & 0.12 & 0.14 \\
\hline $\mathrm{K}_{2} \mathrm{O}$ & 1.22 & 0.79 & 0.75 & 1.11 & 1.02 & 0.55 & 1.08 & 1.14 & 0.83 & 1.12 \\
\hline Total & 93.82 & 87.94 & 89.43 & 97.36 & 96.86 & 97.19 & 92.36 & 97.06 & 97.67 & 91.51 \\
\hline $\mathrm{Si}^{+4}$ & 0.05 & 0.13 & 0.13 & 0.02 & 0.02 & 0.03 & 0.04 & 0.01 & 0.02 & 0.06 \\
\hline $\mathrm{Ti}^{+4}$ & 0.01 & 0.01 & - & 0.01 & 0.01 & - & - & - & - & 0.02 \\
\hline$M n^{+4}$ & 7.40 & 7.15 & 7.20 & 7.48 & 7.46 & 7.46 & 7.38 & 7.48 & 7.48 & 7.30 \\
\hline $\mathrm{Ce}^{+4}$ & - & - & - & $n / a$ & $n / a$ & n/a & - & - & n/a & - \\
\hline $\mathrm{Al}^{+3}$ & 0.07 & 0.13 & 0.11 & 0.07 & 0.06 & 0.05 & 0.08 & 0.07 & 0.08 & 0.09 \\
\hline $\mathrm{Fe}^{+3}$ & 0.13 & 0.27 & 0.27 & 0.06 & 0.09 & 0.15 & 0.11 & 0.06 & 0.07 & 0.13 \\
\hline $\mathrm{Mg}^{+2}$ & - & 0.01 & - & - & - & - & - & - & - & 0.06 \\
\hline $\mathrm{Ca}^{+2}$ & 0.02 & 0.01 & 0.01 & 0.02 & 0.01 & - & 0.02 & 0.01 & 0.01 & 0.02 \\
\hline $\mathrm{Ni}^{+2}$ & 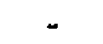 & - & - & - & - & - & 0.02 & - & - & - \\
\hline $\mathrm{Zn}+2$ & - & - & - & - & 0.01 & - & - & - & - & - \\
\hline $\mathrm{Sr}^{+2}$ & - & - & - & - & - & - & - & - & - & - \\
\hline $\mathrm{Ba}^{+2}$ & 0.65 & 0.70 & 0.69 & 0.65 & 0.66 & 0.66 & 0.70 & 0.68 & 0.67 & 0.72 \\
\hline $\mathrm{Pb}^{+2}$ & $\mathrm{n} / \mathrm{a}$ & $\mathrm{n} / \mathrm{a}$ & $\mathrm{n} / \mathrm{a}$ & 0.02 & 0.02 & 0.01 & $\mathrm{n} / \mathrm{a}$ & 0.02 & 0.02 & $n / a$ \\
\hline $\mathrm{Na}^{+1}$ & 0.03 & 0.03 & - & 0.03 & 0.05 & - & 0.06 & 0.03 & 0.03 & 0.04 \\
\hline $\mathrm{K}^{+1}$ & 0.21 & 0.15 & 0.14 & 0.19 & 0.17 & 0.09 & 0.19 & 0.19 & 0.14 & 0.20 \\
\hline Total & 8.57 & 8.60 & 8.55 & 8.54 & 8.55 & 8.46 & 8.61 & 8.55 & 8.52 & 8.64 \\
\hline $\mathrm{O}^{-2}$ & 16.00 & 16.00 & 16.00 & 16.00 & 16.00 & 16.00 & 16.00 & 16.00 & 16.00 & 16.00 \\
\hline
\end{tabular}

-Possible presence of $<0.5 \% \mathrm{CeO}_{2}$

Analyzed but not detected: $\mathrm{Cu}, \mathrm{L} a, \mathrm{Y}, \mathrm{C}$ 
MANGANESE AND IRON OXIDES FROM 2099-2100 FT (cont)

Hollandite

\begin{tabular}{|c|c|c|c|c|c|c|c|c|c|c|}
\hline $\mathrm{SiO}_{2}$ & 0.05 & 0.46 & 0.14 & 0.46 & 0.32 & 0.12 & 0.33 & 1.05 & 1.10 & 1.29 \\
\hline $\mathrm{TiO}_{2}$ & - & - & - & 0.13 & - & - & 0.16 & - & - & - \\
\hline $\mathrm{MnO}_{2}$ & 81.98 & 78.90 & 81.47 & 81.44 & 82.01 & 80.98 & 78.70 & 80.20 & 75.78 & 77.71 \\
\hline $\mathrm{CeO}_{2}{ }^{2}$ & $\mathbf{n} / \mathbf{a}$ & 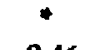 & $n / a$ & $\therefore$ & - & • & • & $\mathrm{n} / \mathrm{a}$ & - & • \\
\hline $\mathrm{Al}_{2} \overline{\mathrm{O}}_{3}$ & 0.35 & 0.46 & 0.41 & 0.49 & 0.42 & 0.28 & 0.30 & 0.69 & 0.68 & 0.56 \\
\hline $\mathrm{Fe}_{2} \mathrm{O}_{3}$ & 0.58 & 1.68 & 0.62 & 1.76 & 1.47 & 0.77 & 1.92 & 4.24 & 3.56 & 3.75 \\
\hline $\mathrm{MgO}^{\circ}$ & - & - & - & - & - & 0.32 & 0.31 & - & - & - \\
\hline $\mathrm{CaO}$ & 0.07 & 0.08 & 0.11 & 0.07 & - & 0.12 & 0.06 & 0.10 & 0.08 & 0.16 \\
\hline $\mathrm{NiO}$ & - & - & - & - & - & - & 0.17 & - & - & - \\
\hline $\mathrm{ZnO}$ & - & - & - & - & - & - & - & - & - & - \\
\hline SrO & - & - & - & - & 0.05 & 0.20 & 0.19 & - & - & 0.23 \\
\hline $\mathrm{BaO}$ & 13.05 & 13.11 & 13.40 & 13.45 & 14.02 & 14.03 & 14.26 & 14.96 & 15.03 & 15.79 \\
\hline PbO & 0.33 & $\mathbf{n} / \mathbf{a}$ & 0.57 & $\mathbf{n} / \mathbf{a}$ & 0.33 & $\mathrm{n} / \mathrm{a}$ & $\mathbf{n} / \mathbf{a}$ & - & - & $n / a$ \\
\hline $\mathrm{Na}_{2} \mathrm{O}$ & 0.19 & 0.16 & 0.14 & 0.10 & 0.13 & 0.16 & 0.13 & 0.17 & 0.21 & 0.18 \\
\hline $\mathrm{K}_{2} \mathrm{O}$ & 1.03 & 0.62 & 1.07 & 0.70 & 0.67 & 1.02 & 0.54 & 0.43 & 0.38 & 0.40 \\
\hline Total & 97.63 & 95.47 & 97.93 & 98.60 & 99.42 & 98.00 & 97.07 & 101.84 & 96.82 & 100.07 \\
\hline $\mathrm{Si}^{+4}$ & 0.01 & 0.06 & 0.02 & 0.06 & 0.04 & 0.02 & 0.04 & 0.13 & 0.15 & 0.17 \\
\hline $\mathrm{Ti}^{+4}$ & - & - & - & 0.01 & - & - & 0.02 & - & 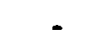 & - \\
\hline $\mathrm{Mn}^{+4}$ & 7.50 & 7.36 & 7.47 & 7.36 & 7.40 & 7.43 & 7.30 & 7.07 & 7.07 & 7.04 \\
\hline $\mathrm{Ce}^{+4}$ & $n / a$ & - & $n / a$ & - & - & - & - & $\mathrm{n} / \mathrm{a}$ & - & - \\
\hline $\mathrm{Al}^{+3}$ & 0.05 & 0.07 & 0.06 & 0.08 & 0.06 & 0.04 & 0.05 & 0.10 & 0.11 & 0.09 \\
\hline $\mathrm{Fe}^{+3}$ & 0.06 & 0.17 & 0.06 & 0.17 & 0.14 & 0.08 & 0.19 & 0.41 & 0.36 & 0.37 \\
\hline $\mathrm{Mg}^{+2}$ & - & - & - & - & - & 0.06 & 0.06 & - & - & - \\
\hline $\mathrm{Ca}^{+2}$ & 0.01 & 0.01 & 0.02 & 0.01 & - & 0.02 & 0.01 & 0.01 & 0.01 & 0.02 \\
\hline $\mathrm{Ni}^{+2}$ & - & - & - & - & - & - & 0.02 & - & - & - \\
\hline $\mathrm{Zn}+2$ & - & - & - & - & - & - & - & - & - & - \\
\hline $\mathrm{Sr}^{+2}$ & - & - & - & - & 0.00 & 0.02 & 0.01 & - & - & 0.02 \\
\hline $\mathrm{Ba}^{+2}$ & 0.68 & 0.69 & 0.70 & 0.69 & 0.72 & 0.73 & 0.75 & 0.75 & 0.79 & 0.81 \\
\hline $\mathrm{Pb}^{+2}$ & 0.01 & $\mathrm{n} / \mathrm{a}$ & 0.02 & $\mathrm{n} / \mathrm{a}$ & 0.01 & $\mathrm{n} / \mathrm{a}$ & $n / a$ & - & - & $\mathrm{n} / \mathrm{a}$ \\
\hline $\mathrm{Na}^{+1}$ & 0.05 & 0.04 & 0.04 & 0.03 & 0.03 & 0.04 & 0.03 & 0.04 & 0.05 & 0.05 \\
\hline $\mathrm{K}^{+1}$ & 0.17 & 0.11 & 0.18 & 0.12 & 0.11 & 0.17 & 0.09 & 0.07 & 0.07 & 0.07 \\
\hline Total & 8.54 & 8.53 & 8.56 & 8.52 & 8.53 & 8.60 & 8.58 & 8.59 & 8.61 & 8.62 \\
\hline $0^{-2}$ & 16.00 & 16.00 & 16.00 & 16.00 & 16.00 & 16.00 & 16.00 & 16.00 & 16.00 & 16.00 \\
\hline
\end{tabular}

- Possible presence of $<0.5 \% \mathrm{CeO}_{2}$

Analyzed but not detected: $\mathrm{Cu}, \mathrm{La}, \mathrm{Y}, \mathrm{Cl}$ 
MANGANESE AND IRON OXIDES

FROM 2099-2100 FT (cont)

Shard-filling Hollandite

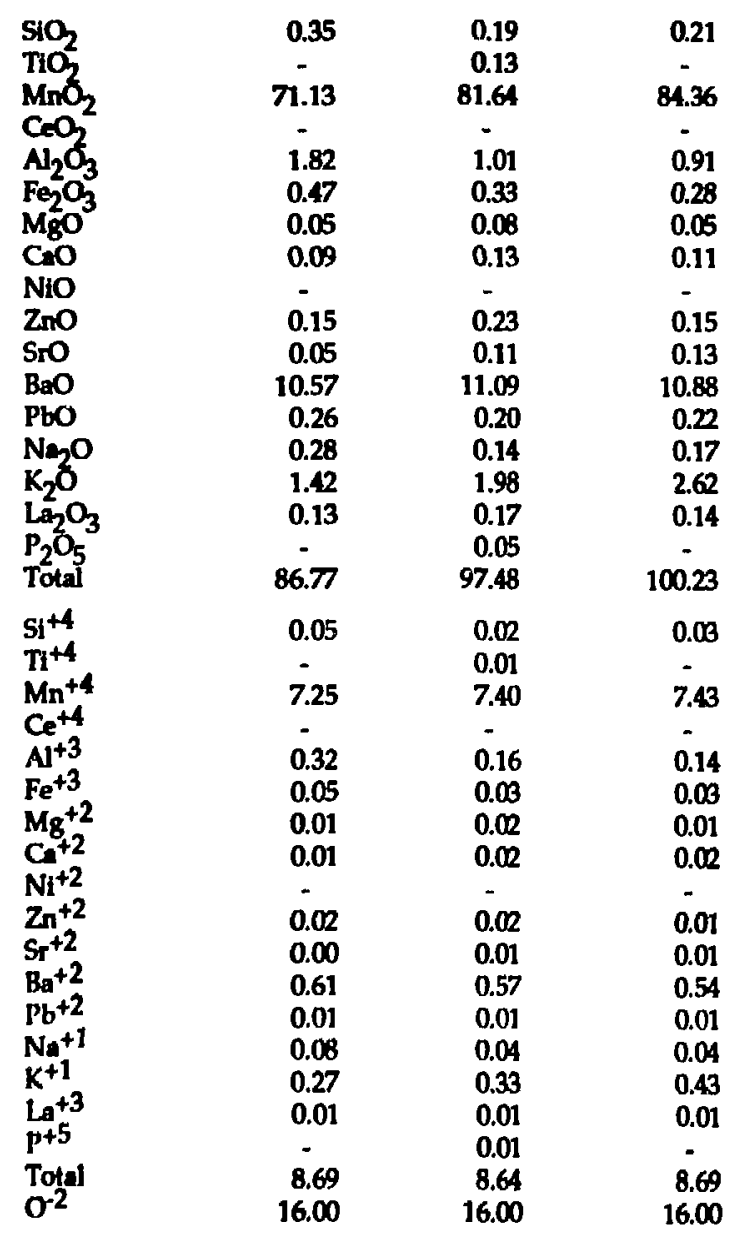

- Posidble presence of $<0.5 \% \mathrm{CeO}_{2}$

Analyzed but not detected: $\mathrm{Cu}_{1} \mathrm{La}, \mathrm{Y}, \mathrm{Cl}$ 
MANGANESE OXIDES FROM USW G-4 2615 FT

Todorokite

\begin{tabular}{|c|c|c|c|c|}
\hline $\mathrm{SiO}_{2}$ & 0.45 & 0.47 & 0.62 & 0.53 \\
\hline $\mathrm{TiO}_{2}^{2}$ & 0.24 & 0.28 & 0.65 & 0.47 \\
\hline $\mathrm{MnO}_{2}$ & 75.99 & 75.42 & 72.57 & 72.69 \\
\hline $\mathrm{CeO}_{2}$ & $\mathbf{n} / \mathbf{a}$ & $\mathrm{n} / \mathrm{a}$ & - & - \\
\hline $\mathrm{Al}_{2} \mathrm{O}_{3}$ & 0.28 & 0.49 & 0.45 & 0.38 \\
\hline $\mathrm{Fe}_{2} \mathrm{O}_{3}$ & 2.48 & 2.52 & 3.01 & 2.49 \\
\hline $\mathrm{MgO}^{\circ}$ & 0.33 & 0.38 & 0.34 & 0.23 \\
\hline $\mathrm{CaO}$ & 2.62 & 2.41 & 2.20 & 2.20 \\
\hline SrO & 1.80 & 1.79 & 1.48 & 1.63 \\
\hline $\mathrm{BaO}$ & 3.26 & 2.67 & 3.75 & 3.08 \\
\hline $\mathrm{PbO}$ & & - & - & 0.08 \\
\hline $\mathrm{Na}_{2} \mathrm{O}$ & 1.37 & 1.55 & 1.17 & 1.19 \\
\hline $\mathrm{K}_{2} \mathrm{O}$ & 0.80 & 0.88 & 0.93 & 0.97 \\
\hline $\mathrm{La}_{2} \mathrm{O}_{3}$ & - & - & - & 0.12 \\
\hline Total & 89.62 & 88.86 & 87.17 & 86.06 \\
\hline $\mathrm{Si}^{+4}$ & 0.06 & 0.06 & 0.09 & 0.08 \\
\hline $\mathrm{Ti}^{+4}$ & 0.02 & 0.03 & 0.07 & 0.05 \\
\hline $\mathrm{Mn}^{+4}$ & 7.18 & 7.15 & 7.06 & 7.15 \\
\hline $\mathrm{Al}^{+3}$ & 0.05 & 0.08 & 0.07 & 0.06 \\
\hline $\mathrm{Fe}^{+3}$ & 0.26 & 0.26 & 0.32 & 0.27 \\
\hline $\mathrm{Mg}^{+2}$ & 0.07 & 0.08 & 0.07 & 0.05 \\
\hline $\mathrm{Ca}^{+2}$ & 0.38 & 0.35 & 0.33 & 0.34 \\
\hline $5 r^{+2}$ & 0.14 & 0.14 & 0.12 & 0.13 \\
\hline $\mathrm{Ba}^{+2}$ & 0.17 & 0.14 & 0.21 & 0.17 \\
\hline $\mathrm{Pb}^{+2}$ & - & - & - & 0.00 \\
\hline $\mathrm{Na}^{+1}$ & 0.36 & 0.41 & 0.32 & 0.33 \\
\hline $\mathrm{K}^{+1}$ & 0.14 & 0.15 & 0.17 & 0.18 \\
\hline $\mathrm{La}^{+3}$ & - & - & - & 0.01 \\
\hline Total & 8.84 & 8.87 & 8.83 & 8.81 \\
\hline & 16.00 & 16.00 & 16.00 & 16.00 \\
\hline
\end{tabular}

Analyzed but not detected: $\mathrm{Co}, \mathrm{W}, \mathrm{Cu}, \mathrm{Ag}, \mathrm{P}, \mathrm{Cl}, \mathrm{Y}, \mathrm{Ni}, \mathrm{Zn}$ 


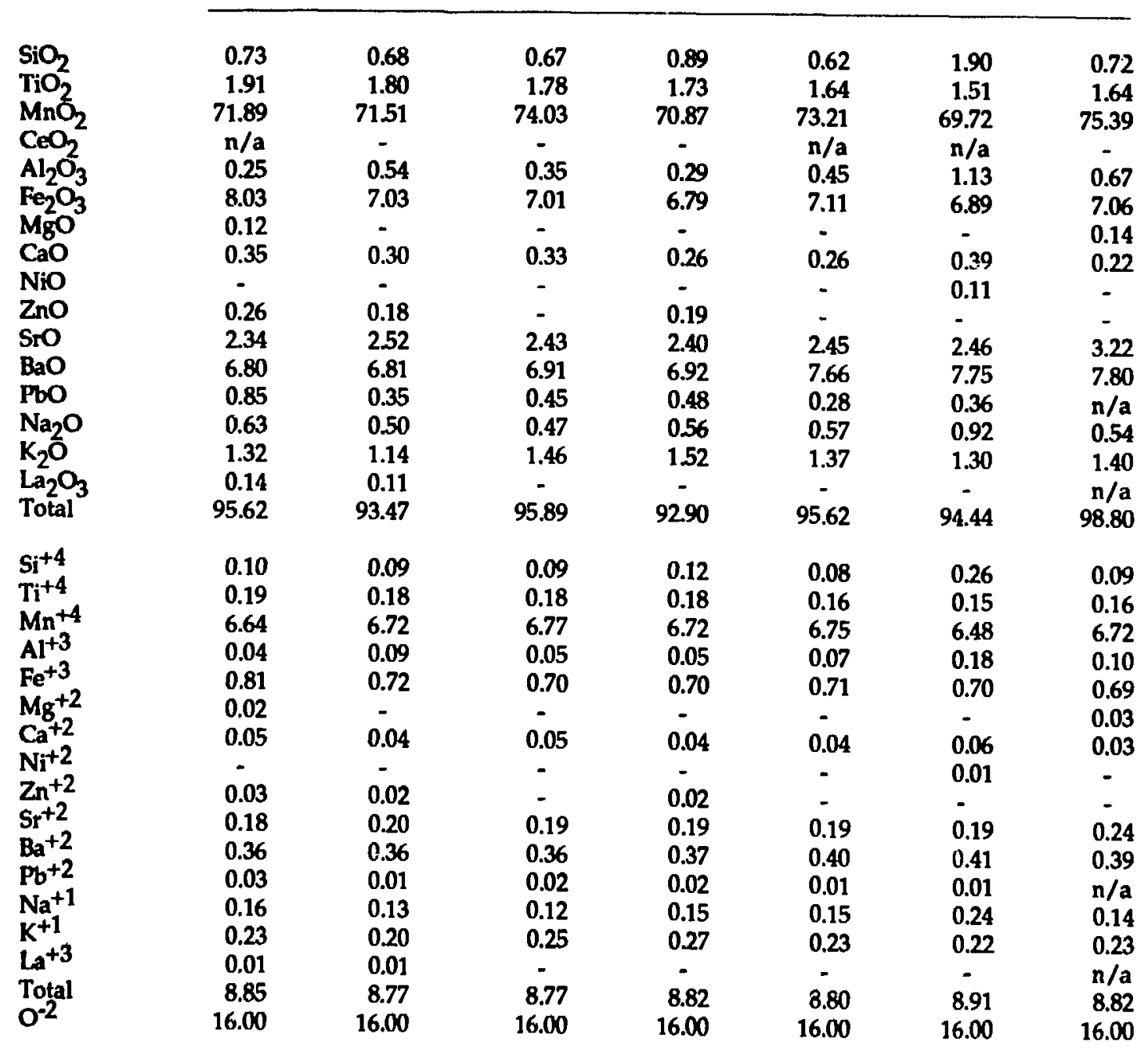

Analyzed but not detected: $\mathrm{P}, \mathrm{Cl}, \mathrm{Co}, \mathrm{Cu}, \mathrm{Y}$ 


\begin{tabular}{|c|c|c|c|c|c|c|c|c|c|c|}
\hline $\mathrm{SiO}_{2}$ & 0.74 & 0.69 & 0.61 & 0.64 & 0.50 & 1.25 & 0.57 & 0.81 & 1.04 & 1.00 \\
\hline $\mathrm{TiO}_{2}$ & 1.10 & 1.07 & 1.25 & 0.76 & 0.87 & 1.75 & 0.69 & 1.39 & 0.96 & 1.45 \\
\hline $\mathrm{MnO}_{2}$ & 77.30 & 72.91 & 71.65 & 73.95 & 72.26 & 71.71 & 77.72 & 72.92 & 71.57 & 72.86 \\
\hline $\mathrm{CeO}_{2}^{-}$ & $*$ & $*$ & * & $\mathbf{n} / \mathbf{a}$ & $\mathbf{n} / \mathbf{a}$ & 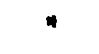 & * & $\mathbf{n} / \mathbf{a}$ & $\mathbf{n} / \mathbf{a}$ & * \\
\hline $\mathrm{Al}_{2} \mathrm{O}_{3}$ & 0.43 & 0.35 & 0.39 & 0.43 & 0.42 & 0.86 & 0.47 & 0.44 & 0.73 & 0.36 \\
\hline $\mathrm{Fe}_{2} \mathrm{O}_{3}$ & 4.82 & 4.88 & 4.50 & 4.47 & 4.37 & 8.36 & 4.17 & 4.86 & 5.02 & 5.14 \\
\hline $\mathrm{MgO}$ & 3.03 & 2.92 & 2.85 & 2.76 & 2.73 & 2.76 & 2.91 & 2.66 & 2.40 & 2.47 \\
\hline $\mathrm{CaO}$ & 1.37 & 1.37 & 1.34 & 1.36 & 1.36 & 1.47 & 1.42 & 1.26 & 1.56 & 1.46 \\
\hline $\mathrm{ZnO}$ & - & - & - & - & - & - & - & - & 0.24 & - \\
\hline $\mathrm{SrO}$ & 0.63 & 0.55 & 0.56 & 0.42 & 0.44 & 0.64 & 0.60 & 0.45 & 0.46 & 0.59 \\
\hline $\mathrm{BaO}$ & 1.48 & 1.64 & 1.90 & 2.02 & 2.03 & 2.22 & 2.30 & 2.55 & 2.68 & 2.69 \\
\hline $\mathrm{PbO}$ & $\mathbf{n} / \mathbf{a}$ & $\mathrm{n} / \mathbf{a}$ & $\mathbf{n} / \mathbf{a}$ & 0.29 & 0.33 & $n / a$ & $\mathrm{n} / \mathrm{a}$ & 0.29 & 0.32 & $\mathbf{n} / \mathbf{a}$ \\
\hline $\mathrm{Na}_{2} \mathrm{O}$ & 1.95 & 2.31 & 1.96 & 1.88 & 2.03 & 1.50 & 2.02 & 1.90 & 1.48 & 1.94 \\
\hline $\mathrm{K}_{2} \mathrm{O}$ & 0.18 & 0.18 & 0.13 & 0.18 & 0.20 & 0.25 & 0.16 & 0.17 & 0.21 & 0.16 \\
\hline $\mathrm{La}_{2} \mathrm{O}_{3}$ & $\mathbf{n} / \mathbf{a}$ & $\mathbf{n} / \mathbf{a}$ & n/a & 0.13 & - & $\mathbf{n} / \mathbf{a}$ & $\mathbf{n} / \mathbf{a}$ & - & - & $\mathbf{n} / \mathbf{a}$ \\
\hline Total & 93.03 & 88.87 & 87.14 & 89.29 & 87.54 & 92.77 & 93.03 & 89.70 & 88.67 & 90.12 \\
\hline $\mathrm{Si}^{+4}$ & 0.09 & 0.09 & 0.08 & 0.09 & 0.07 & 0.16 & 0.07 & 0.11 & 0.14 & 0.13 \\
\hline $\mathrm{Ti}^{+4}$ & 0.11 & 0.11 & 0.13 & 0.08 & 0.09 & 0.17 & 0.07 & 0.14 & 0.10 & 0.15 \\
\hline $\mathrm{Mn}^{+4}$ & 6.83 & 6.77 & 6.79 & 6.86 & 6.85 & 6.41 & 6.91 & 6.75 & 6.72 & 6.72 \\
\hline $\mathrm{Al}^{+3}$ & 0.06 & 0.06 & 0.06 & 0.07 & 0.07 & 0.13 & 0.07 & 0.07 & 0.12 & 0.06 \\
\hline $\mathrm{Fe}^{+3}$ & 0.46 & 0.49 & 0.46 & 0.45 & 0.45 & 0.81 & 0.40 & 0.49 & 0.51 & 0.52 \\
\hline $\mathrm{Mg}^{+2}$ & 0.58 & 0.59 & 0.58 & 0.55 & 0.56 & 0.53 & 0.56 & 0.53 & 0.49 & 0.49 \\
\hline $\mathrm{Ca}+2$ & 0.19 & 0.20 & 0.20 & 0.20 & 0.20 & 0.20 & 0.20 & 0.18 & 0.23 & 0.21 \\
\hline $\mathrm{Zn}+2$ & - & - & - & - & - & - & - & - & 0.02 & 0.21 \\
\hline $\mathrm{Sr}+2$ & 0.05 & 0.04 & 0.04 & 0.03 & 0.04 & 0.05 & 0.04 & 0.03 & 0.04 & 0.05 \\
\hline $\mathrm{Ba}+2$ & 0.07 & 0.09 & 0.10 & 0.11 & 0.11 & 0.11 & 0.12 & 0.13 & 0.14 & 0.14 \\
\hline $\mathrm{Pb}^{+2}$ & $\mathrm{n} / \mathrm{a}$ & $\mathrm{n} / \mathrm{a}$ & $\mathrm{n} / \mathrm{a}$ & 0.01 & 0.01 & $\mathrm{n} / \mathrm{a}$ & $\begin{array}{l}0.12 \\
\mathrm{n} / \mathrm{a}\end{array}$ & 0.01 & 0.01 & $\begin{array}{l}0.14 \\
\mathrm{n} / \mathrm{a}\end{array}$ \\
\hline $\mathrm{Na}^{+1}$ & 0.48 & 0.60 & 0.52 & 0.49 & 0.54 & 0.38 & 0.50 & 0.49 & 0.39 & $\begin{array}{l}\mathrm{n} / \mathrm{a} \\
0.50\end{array}$ \\
\hline $\mathrm{K}^{+1}$ & 0.03 & 0.03 & 0.02 & 0.03 & 0.04 & 0.04 & 0.03 & 0.03 & 0.04 & $\begin{array}{l}0.30 \\
0.03\end{array}$ \\
\hline $\mathrm{La}^{+3}$ & $\mathrm{n} / \mathrm{a}$ & $\mathrm{n} / \mathrm{a}$ & $\mathrm{n} / \mathrm{a}$ & 0.01 & $\begin{array}{c}0.04 \\
-\end{array}$ & $\begin{array}{l}0.04 \\
\mathrm{n} / \mathrm{a}\end{array}$ & $\mathrm{n} / \mathrm{a}$ & - & - & $\begin{array}{l}0.03 \\
\mathrm{n} / \mathrm{a}\end{array}$ \\
\hline Total & 8.96 & 9.07 & 9.00 & 8.97 & 9.02 & 9.00 & 8.97 & 8.98 & 8.94 & $\begin{array}{l}\text { n/a } \\
898\end{array}$ \\
\hline $\mathrm{O}^{-2}$ & 16.00 & 16.00 & 16.00 & 16.00 & 16.00 & 16.00 & 16.00 & 16.00 & 16.00 & $\begin{array}{r}8.98 \\
16.00\end{array}$ \\
\hline
\end{tabular}

\footnotetext{
is "Possible presence of $\leq 0.5 \% \mathrm{CeO}_{2}$.
} 


\begin{tabular}{|c|c|c|c|c|c|}
\hline $\mathrm{SiO}_{2}$ & 0.99 & 1.18 & 1.20 & 123 & 1.86 \\
\hline $\mathrm{TiO}_{2}$ & 1.22 & 2.00 & 2.02 & 2.03 & 1.88 \\
\hline $\mathrm{MnO}_{2}$ & 71.16 & 72.65 & 66.64 & 69.55 & 68.58 \\
\hline $\mathrm{CeO}_{2}{ }^{2}$ & $\mathbf{n} / \mathbf{a}$ & $*$ & $\mathbf{n} / \mathbf{a}$ & * & $\mathbf{n} / \mathbf{a}$ \\
\hline $\mathrm{Al}_{2} \mathrm{O}_{3}$ & 0.38 & 0.66 & 1.63 & 0.54 & 0.65 \\
\hline $\mathrm{Fe}_{2} \mathrm{O}_{3}$ & 4.51 & 7.35 & 7.04 & 7.32 & 7.37 \\
\hline $\mathrm{MgO}^{2}$ & 2.55 & 2.19 & 1.98 & 1.78 & 1.87 \\
\hline $\mathrm{CaO}$ & 1.36 & 1.17 & 1.05 & 1.28 & 1.17 \\
\hline $\mathrm{ZnO}$ & - & - & 0.18 & 0.24 & - \\
\hline $\mathrm{SrO}$ & 0.40 & 0.66 & 0.52 & 0.85 & 0.49 \\
\hline $\mathrm{BaO}$ & 2.85 & 2.85 & 2.98 & 3.16 & 3.27 \\
\hline $\mathrm{PbO}$ & 0.27 & $\mathrm{n} / \mathrm{a}$ & 0.92 & $n / a$ & 0.62 \\
\hline $\mathrm{Na}_{2} \mathrm{O}$ & 1.90 & 1.38 & 1.34 & 1.56 & 1.52 \\
\hline $\mathrm{K}_{2} \mathrm{O}$ & 0.20 & 0.74 & 0.71 & 0.57 & 0.50 \\
\hline $\mathrm{La}_{2} \mathrm{O}_{3}$ & - & $\mathbf{n} / \mathbf{a}$ & 0.11 & $\mathbf{n} / \mathbf{a}$ & 0.13 \\
\hline Total & 87.79 & 92.83 & 88.32 & 90.11 & 89.91 \\
\hline $\mathrm{Si}^{+4}$ & 0.14 & 0.15 & 0.17 & 0.17 & 0.25 \\
\hline $\mathrm{Ti}^{+4}$ & 0.13 & 0.20 & 0.21 & 0.21 & 0.19 \\
\hline $\mathrm{Mn}^{+4}$ & 6.75 & 6.53 & 6.35 & 6.48 & 6.40 \\
\hline $\mathrm{Al}^{+3}$ & 0.06 & 0.10 & 0.26 & 0.09 & 0.10 \\
\hline $\mathrm{Fe}^{+3}$ & 0.47 & 0.72 & 0.73 & 0.74 & 0.75 \\
\hline $\mathrm{Mg}+2$ & 0.52 & 0.42 & 0.41 & 0.36 & 0.38 \\
\hline $\mathrm{Ca}^{+2}$ & 0.20 & 0.16 & 0.16 & 0.18 & 0.17 \\
\hline $\mathrm{Zn}^{+2}$ & - & - & 0.02 & 0.02 & - \\
\hline $\mathrm{Sr}^{+2}$ & 0.03 & 0.05 & 0.04 & 0.07 & 0.04 \\
\hline $\mathrm{Ba}+2$ & 0.15 & 0.15 & 0.16 & 0.17 & 0.17 \\
\hline $\mathrm{Pb}^{+2}$ & 0.01 & $\mathbf{n} / \mathbf{a}$ & 0.03 & $n / a$ & 0.02 \\
\hline $\mathrm{Na}^{+1}$ & 0.51 & 0.35 & 0.36 & 0.41 & 0.40 \\
\hline$K^{+1}$ & 0.04 & 0.12 & 0.12 & 0.10 & 0.09 \\
\hline $\mathrm{La}^{+3}$ & - & $\mathrm{n} / \mathbf{a}$ & 0.01 & $n / a$ & 0.01 \\
\hline Total & 9.00 & 8.95 & 9.02 & 8.99 & 8.97 \\
\hline $\mathrm{O}^{-2}$ & 16.00 & 16.00 & 16.00 & 16.00 & 16.00 \\
\hline
\end{tabular}

"Possible presence of $\leq 0.5 \% \mathrm{CeO}_{2}$

Analyzed but not detected: $\mathrm{P}, \mathrm{Cl}, \mathrm{Cu}, \mathrm{Mo}, \mathrm{Sc}, \mathrm{W}, \mathrm{Ta}, \mathrm{Cd}, \mathrm{Y}, \mathrm{Ni}$ 
MANGANESE OXIDES FR0M 2814 FT

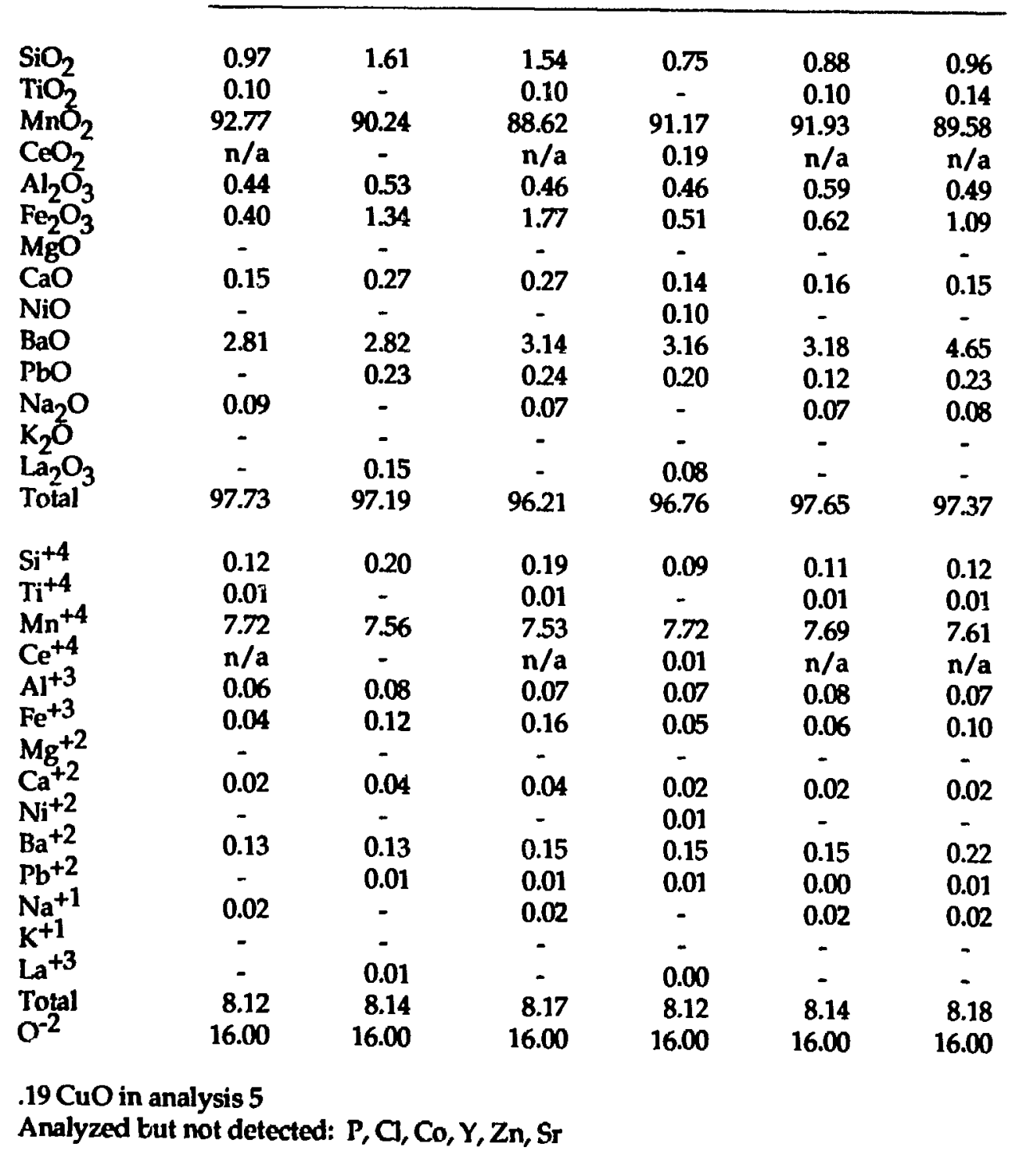




\begin{tabular}{|c|c|c|c|c|c|c|c|c|c|c|}
\hline $\mathrm{SiO}_{2}$ & 0.97 & 1.70 & 0.87 & 1.02 & 0.85 & 0.77 & 1.22 & 0.52 & 1.66 & 0.28 \\
\hline $\mathrm{TiO}_{2}$ & 0.43 & 0.24 & 0.30 & 0.66 & 0.68 & 0.34 & 0.73 & - & 0.15 & 0.15 \\
\hline $\mathrm{MnO}_{2}$ & 84.08 & 83.00 & 84.33 & 74.62 & 75.98 & 79.12 & 66.54 & 82.21 & 71.45 & 77.57 \\
\hline $\mathrm{CeO}_{2}{ }^{2}$ & $*$ & 4 & $\mathrm{n} / \mathrm{a}$ & n/a & $\because$ & $\mathbf{n} / \mathbf{a}$ & $\mathbf{n} / \mathbf{a}$ & $\mathbf{n} / \mathbf{a}$ & $\mathrm{n} / \mathrm{a}$ & 0.50 \\
\hline $\mathrm{Al}_{2} \mathrm{O}_{3}$ & 1.20 & 1.24 & 0.76 & 0.98 & 1.47 & 0.67 & 1.16 & 0.69 & 0.94 & 0.32 \\
\hline $\mathrm{Fe}_{2} \mathrm{O}_{3}$ & 292 & 2.60 & 2.10 & 4.90 & 4.44 & 3.16 & 1275 & 0.86 & 6.22 & 0.81 \\
\hline $\mathrm{MgO}^{2}$ & - & - & - & - & 0.38 & 0.05 & - & - & 0.12 & 0.22 \\
\hline $\mathrm{CaO}$ & 0.35 & 0.36 & 0.61 & 0.40 & 0.37 & 0.64 & 0.31 & 0.78 & 0.97 & 0.72 \\
\hline $\mathrm{ZnO}$ & - & - & 0.18 & - & - & - & - & - & 0.25 & 0.36 \\
\hline Sro & - & 0.15 & 0.28 & 0.15 & 0.24 & 0.93 & 0.14 & 0.78 & 0.88 & 1.09 \\
\hline $\mathrm{BaO}$ & 1.46 & 1.84 & 3.86 & 5.38 & 5.59 & 6.99 & 7.69 & 8.30 & 8.69 & 8.88 \\
\hline $\mathrm{PbO}$ & $n / a$ & $n / a$ & - & 0.18 & $\mathrm{n} / \mathrm{a}$ & 0.24 & 0.28 & 0.52 & 0.56 & 0.35 \\
\hline $\mathrm{Na}_{2} \mathrm{O}$ & - & - & 0.18 & 0.08 & - & 0.30 & 0.09 & 0.37 & 0.43 & 0.48 \\
\hline $\mathrm{K}_{2} \mathrm{O}$ & - & - & 0.16 & 0.14 & 0.09 & 0.45 & 0.12 & 0.63 & 0.64 & 0.35 \\
\hline $\mathrm{La}_{2} \mathrm{O}_{3}$ & $\mathrm{n} / \mathrm{a}$ & $n / a$ & - & 0.16 & $n / a$ & 0.12 & - & - & - & - \\
\hline $\mathrm{P}_{2} \mathrm{O}_{5}$ & $\mathbf{n} / \mathbf{a}$ & $\mathbf{n} / \mathbf{a}$ & - & - & $\mathbf{n} / \mathbf{a}$ & - & 0.06 & - & - & - \\
\hline Total & 91.41 & 91.13 & 93.63 & 88.67 & 90.09 & 93.78 & 91.09 & 95.66 & 92.96 & 92.08 \\
\hline $\mathrm{Si}^{+4}$ & 0.12 & 0.22 & 0.11 & 0.14 & 0.11 & 0.10 & 0.17 & 0.07 & 0.23 & 0.04 \\
\hline $\mathrm{Ti}^{+4}$ & 0.04 & 0.02 & 0.03 & 0.07 & 0.07 & 0.03 & 0.08 & - & 0.02 & 0.02 \\
\hline $\mathrm{Mn}^{+4}$ & 7.43 & 7.35 & 7.45 & 7.09 & 7.08 & 7.24 & 6.36 & 7.43 & 6.74 & 7.39 \\
\hline $\mathrm{Ce}^{+4}$ & - & - & $\mathrm{n} / \mathrm{a}$ & $\mathrm{n} / \mathrm{a}$ & - & $\mathrm{n} / \mathrm{a}$ & $\mathrm{n} / \mathrm{a}$ & $\mathrm{n} / \mathrm{a}$ & $\mathrm{n} / \mathrm{a}$ & 0.02 \\
\hline $\mathrm{Al}^{+3}$ & 0.18 & 0.19 & 0.11 & 0.16 & 0.23 & 0.10 & 0.19 & 0.11 & 0.15 & 0.05 \\
\hline $\mathrm{Fe}^{+3}$ & 0.28 & 0.25 & 0.20 & 0.51 & 0.45 & 0.31 & 1.33 & 0.08 & 0.64 & 0.08 \\
\hline $\mathbf{M g}+2$ & - & - & - & - & 0.08 & 0.01 & - & - & 0.02 & 0.05 \\
\hline $\mathrm{Ca}^{+2}$ & 0.05 & 0.05 & 0.08 & 0.06 & 0.05 & 0.09 & 0.05 & 0.11 & 0.14 & 0.11 \\
\hline $\mathrm{Zn}+2$ & - & - & 0.02 & - & - & - & - & - & 0.03 & 0.04 \\
\hline $\mathrm{Sr}^{+2}$ & - & 0.01 & 0.02 & 0.01 & 0.02 & 0.07 & 0.01 & 0.06 & 0.07 & 0.09 \\
\hline $\mathrm{Ba}+2$ & 0.07 & 0.09 & 0.19 & 0.29 & 0.30 & 0.36 & 0.42 & 0.43 & 0.46 & 0.48 \\
\hline $\mathrm{Pb}^{+2}$ & $n / a$ & $n / a$ & - & 0.01 & $n / a$ & 0.01 & 0.01 & 0.02 & 0.02 & 0.01 \\
\hline $\mathrm{Na}^{+1}$ & - & - & 0.04 & 0.02 & - & 0.08 & 0.02 & 0.09 & 0.11 & 0.13 \\
\hline $\mathrm{K}^{+1}$ & - & $\cdot$ & 0.03 & 0.02 & 0.02 & 0.08 & 0.02 & 0.11 & 0.11 & 0.06 \\
\hline $\mathrm{La}^{+3}$ & $\mathbf{n} / \mathbf{a}$ & $n / a$ & - & 0.01 & $\mathrm{n} / \mathrm{a}$ & 0.01 & - & - & - & - \\
\hline+5 & $\mathrm{n} / \mathrm{a}$ & n/a & - & - & $\mathrm{n} / \mathrm{a}$ & - & 0.01 & - & - & - \\
\hline Total & 8.18 & 8.19 & 8.29 & 8.39 & 8.40 & 8.49 & 8.65 & 8.50 & 8.74 & 8.56 \\
\hline $\mathrm{O}^{-2}$ & 16.00 & 16.00 & 16.00 & 16.00 & 16.00 & 16.00 & 16.00 & 16.00 & 16.00 & 16.00 \\
\hline
\end{tabular}

- Possible presence of $<0.5 \% \mathrm{CeO}_{2}$

** Possible presence of $>0.5 \% \mathrm{CeO}_{2}$

Analyzed but not detected: $\mathrm{C}, \mathrm{Y}, \mathrm{Ni}$ 
MANGANESE OXIDES FROM 2854 FT (cont)

\begin{tabular}{|c|c|c|c|c|c|c|c|c|c|c|}
\hline $\mathrm{SiO}_{2}$ & 0.42 & 0.51 & 1.20 & 124 & 0.38 & 0.41 & 0.39 & 0.40 & 0.42 & 0.34 \\
\hline $\mathrm{TiO}_{2}$ & - & 0.11 & 1.00 & 0.57 & 0.37 & - & 0.29 & - & 0.14 & 0.34 \\
\hline $\mathrm{MnO}_{2}$ & 79.40 & 82.41 & 74.21 & 67.82 & 77.34 & 79.25 & 77.52 & 77.73 & 78.62 & 74.78 \\
\hline $\begin{array}{l}\mathrm{CeO}_{2} \\
\mathrm{Al}_{2} \mathrm{O}_{2}\end{array}$ & $\begin{array}{l}n / a \\
0.42\end{array}$ & $\begin{array}{l}n / a \\
0.74\end{array}$ & 1.67 & $\begin{array}{l}n / a \\
078\end{array}$ & $\begin{array}{l}0.66 \\
0.38\end{array}$ & $\begin{array}{l}n / a \\
0.43\end{array}$ & $n / a$ & $n / a$ & $\begin{array}{l}n / a \\
0.37\end{array}$ & $\begin{array}{l}n / a \\
0.43\end{array}$ \\
\hline $\begin{array}{l}\mathrm{Al}_{2} \mathrm{O}_{3} \\
\mathrm{Fe}_{2} \mathrm{O}_{3}\end{array}$ & $\begin{array}{l}0.42 \\
0.68\end{array}$ & $\begin{array}{l}0.74 \\
0.80\end{array}$ & $\begin{array}{l}1.67 \\
6.53\end{array}$ & $\begin{array}{l}0.78 \\
8.85\end{array}$ & $\begin{array}{l}0.38 \\
217\end{array}$ & $\begin{array}{l}0.43 \\
1.01\end{array}$ & $\begin{array}{l}.41 \\
1.98\end{array}$ & $\begin{array}{l}0.40 \\
1.08\end{array}$ & 1.15 & $\begin{array}{l}0.43 \\
1.98\end{array}$ \\
\hline $\mathrm{MgO}^{3}$ & 0.09 & - & - & 0.08 & 0.11 & 0.07 & 0.14 & 0.14 & 0.21 & 0.10 \\
\hline $\mathrm{CaO}$ & 0.78 & 0.70 & 0.36 & 0.73 & 0.62 & 0.72 & 0.72 & 0.77 & 0.94 & 0.69 \\
\hline $\mathrm{ZnO}$ & 0.30 & - & - & - & 0.27 & 0.24 & 0.18 & 0.18 & 0.29 & - \\
\hline SrO & 1.60 & 0.60 & 0.43 & 0.60 & $1.40^{\circ}$ & 1.46 & 1.51 & 1.33 & 1.03 & 1.36 \\
\hline $\mathrm{BaO}$ & 8.94 & 8.98 & 9.02 & 9.06 & 9.16 & 9.17 & 9.27 & 9.27 & 9.79 & 9.81 \\
\hline $\mathrm{PbO}$ & 0.17 & 0.65 & $\mathrm{n} / \mathrm{a}$ & 0.72 & 0.15 & - & - & 0.18 & 0.52 & 0.14 \\
\hline $\mathrm{Na}_{2} \mathrm{O}$ & 0.64 & 0.37 & 0.14 & 0.26 & 0.55 & 0.54 & 0.61 & 0.46 & 0.53 & 0.56 \\
\hline $\mathrm{K}_{2} \mathrm{\delta}$ & 0.79 & 0.53 & 0.20 & 0.35 & 0.30 & 0.63 & 0.62 & 0.80 & 0.59 & 0.61 \\
\hline $\mathrm{La}_{2} \mathrm{O}_{3}$ & 0.13 & - & $\mathbf{n} / \mathbf{a}$ & $\cdot$ & - & - & - & 0.11 & - & - \\
\hline $\mathrm{P}_{2} \mathrm{O}_{5}$ & - & - & $\mathrm{n} / \mathrm{a}$ & - & - & - & - & - & 0.17 & - \\
\hline Total & 94.36 & 96.40 & 94.76 & 91.06 & 93.91 & 93.93 & 93.64 & 9290 & 94.77 & 91.14 \\
\hline $\mathrm{Si}^{+4}$ & 0.06 & 0.07 & 0.16 & 0.17 & 0.05 & 0.06 & 0.05 & 0.05 & 0.06 & 0.05 \\
\hline $\mathrm{Ti}^{+4}$ & - & 0.01 & 0.10 & 0.06 & 0.04 & - & 0.03 & - & 0.01 & 0.04 \\
\hline $\mathrm{Mn}^{+4}$ & 7.38 & 7.42 & 6.77 & 6.58 & 7.25 & 7.38 & 7.27 & 7.35 & 7.30 & 7.25 \\
\hline $\mathrm{Ce}^{+4}$ & $\mathrm{n} / \mathrm{a}$ & $\mathbf{n} / \mathbf{a}$ & - & $\mathrm{n} / \mathrm{a}$ & 0.03 & $\mathrm{n} / \mathbf{a}$ & $\mathrm{n} / \mathrm{a}$ & $11 / a$ & $n / a$ & $\mathrm{n} / \mathrm{a}$ \\
\hline $\mathrm{Al}^{+3}$ & 0.07 & 0.11 & 0.26 & 0.13 & 0.06 & 0.07 & 0.07 & 0.07 & 0.06 & 0.07 \\
\hline $\mathrm{Fe}^{+3}$ & 0.07 & 0.08 & 0.65 & 0.94 & 0.22 & 0.10 & 0.20 & 0.11 & 0.12 & 0.21 \\
\hline $\mathbf{M g}^{+2}$ & 0.02 & - & - & 0.02 & 0.02 & 0.01 & 0.03 & 0.03 & 0.04 & 0.02 \\
\hline $\mathrm{Ca}^{+2}$ & 0.11 & 0.10 & 0.05 & 0.11 & 0.09 & 0.10 & 0.10 & 0.11 & 0.14 & 0.10 \\
\hline $\mathrm{Zn}^{+2}$ & 0.03 & - & - & - & 0.03 & 0.02 & 0.02 & 0.02 & 0.03 & - \\
\hline $5 r^{+2}$ & 0.12 & 0.05 & 0.03 & 0.05 & 0.11 & 0.11 & 0.12 & 0.11 & 0.08 & 0.11 \\
\hline $\mathrm{Ba}^{+2}$ & 0.47 & 0.46 & 0.47 & 0.50 & 0.49 & 0.48 & 0.49 & 0.50 & 0.52 & 0.54 \\
\hline $\mathrm{Pb}^{+2}$ & 0.01 & 0.02 & $\mathbf{n} / \mathbf{a}$ & 0.03 & 0.01 & - & - & 0.01 & 0.02 & 0.01 \\
\hline $\mathrm{Na}^{+1}$ & 0.17 & 0.09 & 0.04 & 0.07 & 0.14 & 0.14 & 0.16 & 0.12 & 0.14 & 0.15 \\
\hline $\mathrm{K}^{+1}$ & 0.14 & 0.09 & 0.03 & 0.06 & 0.05 & 0.11 & 0.11 & 0.14 & 0.10 & 0.11 \\
\hline $\mathrm{La}^{+3}$ & 0.01 & - & $\mathrm{n} / \mathrm{a}$ & - & - & - & - & 0.01 & - & - \\
\hline $\mathrm{p}+5$ & - & - & $n / a$ & - & - & - & - & - & 0.02 & - \\
\hline $\begin{array}{l}\text { Total } \\
\mathrm{O}^{-2}\end{array}$ & $\begin{array}{r}8.64 \\
16.00\end{array}$ & $\begin{array}{r}8.50 \\
16.00\end{array}$ & $\begin{array}{r}8.55 \\
16.00\end{array}$ & $\begin{array}{r}8.72 \\
16.00\end{array}$ & $\begin{array}{r}8.59 \\
16.00\end{array}$ & $\begin{array}{r}8.60 \\
16.00\end{array}$ & $\begin{array}{r}8.65 \\
16.00\end{array}$ & $\begin{array}{r}8.63 \\
16.00\end{array}$ & $\begin{array}{r}8.63 \\
16.00\end{array}$ & $\begin{array}{r}8.66 \\
16.00\end{array}$ \\
\hline
\end{tabular}




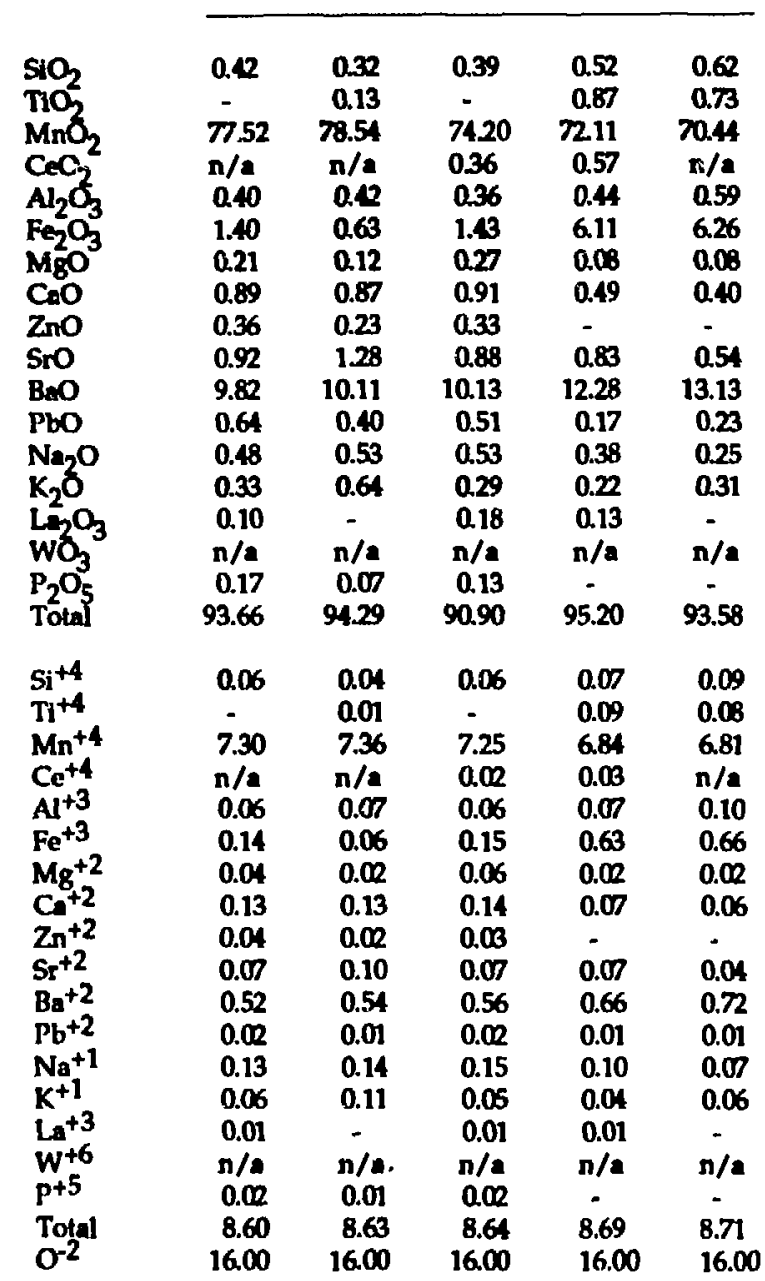

Hollandite

\begin{tabular}{ccc}
\hline & & \\
0.44 & 0.37 & 0.21 \\
0.99 & 0.84 & 0.90 \\
63.15 & 64.71 & 65.84 \\
-.20 & - & - \\
1.20 & 0.94 & 0.90 \\
8.51 & 8.33 & 8.62 \\
0.06 & 0.07 & 0.06 \\
0.11 & 0.15 & 0.13 \\
- & 0.22 & 0.31 \\
- & - & - \\
13.95 & 13.62 & 14.69 \\
0.42 & 0.35 & 0.16 \\
0.08 & 0.11 & - \\
0.09 & 0.11 & 0.10 \\
- & 0.12 & - \\
2.00 & 2.62 & 2.89 \\
$n / a$ & $n n / a$ & $n / a$ \\
91.00 & 92.66 & 94.81 \\
& & \\
0.06 & 0.05 & 0.03 \\
0.11 & 0.09 & 0.10 \\
6.41 & 6.46 & 6.46 \\
- & - & - \\
0.21 & 0.16 & 0.15 \\
0.94 & 0.91 & 0.92 \\
0.01 & 0.02 & 0.01 \\
0.02 & 0.02 & 0.00 \\
- & 0.02 & 0.03 \\
- & - & - \\
0.80 & 0.77 & 0.82 \\
0.02 & 0.01 & 0.01 \\
0.02 & 0.08 & - \\
0.02 & 0.02 & 0.02 \\
- & 0.01 & - \\
0.08 & 0.10 & 0.11 \\
$n / a$ & $n / a$ & $n / a$ \\
8.70 & 8.69 & 8.67 \\
16.00 & 16.00 & 16.00 \\
& &
\end{tabular}

Pyrolusite

\begin{tabular}{cc}
\hline & \\
0.99 & 1.19 \\
0.29 & 0.34 \\
87.87 & 88.20 \\
0.39 & 0.87 \\
2.30 & 0.84 \\
2.28 & 2.25 \\
0.04 & 0.05 \\
0.48 & 0.47 \\
- & 0.16 \\
0.15 & 0.23 \\
2.36 & 2.03 \\
0.13 & 0.19 \\
0.09 & 0.19 \\
0.09 & 0.15 \\
0.12 & 0.15 \\
- & - \\
$n / a$ & $n / a$ \\
97.49 & 97.36 \\
& \\
0.12 & 0.14 \\
0.03 & 0.03 \\
7.33 & 7.42 \\
0.02 & 0.04 \\
0.33 & 0.12 \\
0.21 & 0.21 \\
0.01 & 0.01 \\
0.06 & 0.06 \\
- & 0.01 \\
0.01 & 0.06 \\
0.11 & 0.10 \\
0.00 & 0.01 \\
- & 0.04 \\
0.01 & 0.02 \\
0.01 & 0.01 \\
- & - \\
$n / a$ & $n / a$ \\
8.24 & 8.24 \\
16.00 & 16.00 \\
& \\
\hline
\end{tabular}

Todoroktte?

\begin{tabular}{cc}
\hline & \\
\hline 0.46 & 0.63 \\
0.20 & 0.72 \\
77.17 & 69.00 \\
0.56 & 0.29 \\
0.51 & 0.48 \\
2.80 & 8.38 \\
0.10 & 0.09 \\
0.77 & 0.43 \\
0.33 & 0.26 \\
1.18 & 0.39 \\
8.85 & 12.43 \\
0.17 & 0.20 \\
0.51 & 0.20 \\
0.61 & 0.27 \\
- & 0.10 \\
- & 0.50 \\
$\mathbf{n} / \mathrm{a}$ & $\mathbf{n} / \mathrm{a}$ \\
94.22 & 94.37 \\
& \\
0.06 & 0.09 \\
0.02 & 0.08 \\
7.19 & 6.64 \\
0.03 & 0.01 \\
0.08 & 0.08 \\
0.28 & 0.88 \\
0.02 & 0.02 \\
0.11 & 0.06 \\
0.03 & 0.03 \\
0.09 & 0.03 \\
0.47 & 0.68 \\
0.01 & 0.01 \\
0.13 & 0.05 \\
0.10 & 0.05 \\
- & 0.01 \\
- & 0.02 \\
$\mathbf{n} / \mathrm{a}$ & $\mathbf{n} / \mathrm{a}$ \\
8.64 & 8.72 \\
16.00 & 16.00 \\
& \\
\end{tabular}

$0.10 \%$ NIO in the sccond hollandite analysis

Anslyzed but not detected: $\mathrm{C}, \mathrm{Y}, \mathrm{Ni}$ 
Bledes (Fig. 19)

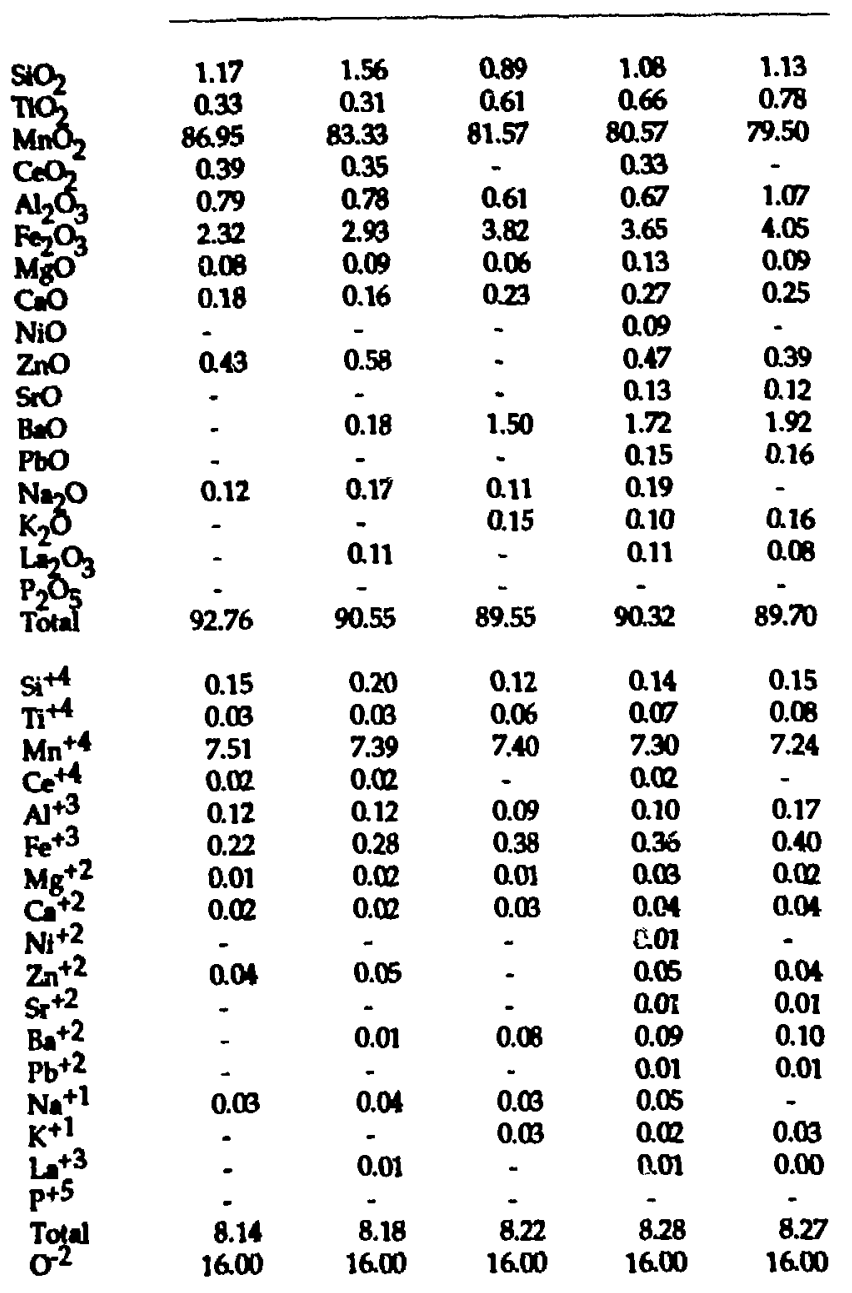

Lobes

\begin{tabular}{|c|c|c|c|c|c|c|c|c|}
\hline 0.40 & 0.53 & 1.37 & 0.46 & 0.44 & 0.64 & 0.86 & 0.79 & 0.28 \\
\hline 0.49 & $\mathbf{0 . 6 1}$ & 1.68 & 0.34 & 0.34 & 0.84 & 1.60 & 1.84 & 0.25 \\
\hline 74.63 & 75.03 & 61.77 & 77.85 & 79.28 & 74.49 & 64.4 & 68.29 & 80.53 \\
\hline 0.17 & 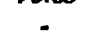 & 0.27 & 0.37 & 0.41 & 0.29 & 0.24 & - & 0.20 \\
\hline 0.35 & 0.37 & 0.58 & 0.51 & 0.50 & 0.58 & 0.64 & 0.69 & 0.49 \\
\hline 3.68 & 3.99 & 8.66 & 291 & 2.65 & 4.79 & 6.03 & 6.15 & 1.31 \\
\hline 0.18 & 0.17 & 0.16 & $\mathbf{0 . 1 1}$ & 0.10 & 0.10 & 0.10 & 0.10 & 0.12 \\
\hline 1.41 & 1.33 & 0.92 & 0.79 & 0.74 & 0.54 & 0.71 & 0.66 & 0.66 \\
\hline- & - & - & - & - & - & - & - & - \\
\hline 0.28 & - & 0.35 & 0.18 & 0.18 & 0.19 & - & - & 0.16 \\
\hline 1.99 & 1.87 & 1.26 & 1.33 & 1.26 & 1.26 & 1.03 & 1.02 & 1.13 \\
\hline 4.51 & 4.54 & 6.77 & 7.10 & 7.34 & 7.49 & 7.60 & 7.68 & 8.50 \\
\hline 0.21 & 0.29 & 0.68 & 0.26 & 0.30 & 0.32 & 0.39 & 0.34 & 0.29 \\
\hline 0.92 & 0.73 & 0.40 & 0.57 & 0.41 & 0.38 & 0.32 & 0.37 & 0.42 \\
\hline 1.36 & 1.13 & 0.72 & 1.84 & 1.66 & 1.78 & 1.65 & 1.64 & 1.78 \\
\hline 0.19 & 0.19 & 0.14 & 0.25 & 0.19 & 0.25 & 0.12 & 0.16 & 0.20 \\
\hline- & - & - & - & - & - & - & - & 0.08 \\
\hline 90.77 & 90.78 & 85.73 & 94.87 & 95.80 & 93.94 & 85.73 & 89.73 & 96.40 \\
\hline 0.05 & 0.07 & 0.20 & 0.06 & 0.06 & 0.09 & 0.13 & 0.11 & 0.04 \\
\hline 0.05 & 0.06 & 0.19 & 0.03 & 0.03 & 0.09 & 0.18 & 0.20 & 0.02 \\
\hline 7.09 & 7.09 & 6.35 & 7.17 & 7.22 & 6.96 & 6.64 & 6.69 & 7.32 \\
\hline 0.01 & - & 0.01 & $0.0 \mathbf{R}$ & $\mathbf{0 . 0 2}$ & 0.01 & 0.01 & - & 0.01 \\
\hline 0.06 & 0.06 & 0.10 & 0.08 & 0.08 & 0.09 & 0.11 & 0.12 & 0.08 \\
\hline 0.38 & 0.41 & 0.97 & 0.29 & 0.26 & 0.49 & 0.68 & 0.66 & 0.13 \\
\hline a.04 & 0.03 & 0.04 & $0, \mathbb{Q}$ & $\mathbf{0 . 0}$ & 0.02 & $0.0 \mathbf{R}$ & 0.02 & 0.02 \\
\hline 0.21 & 0.19 & 0.15 & 0.11 & 0.10 & 0.08 & 0.11 & 0.10 & 0.09 \\
\hline . & - & - & - & - & - & - & 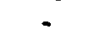 & - \\
\hline 0.03 & . & 0.04 & $0 . \mathbf{Q}$ & $\mathbf{O Q R}$ & 0.08 & - & - & 0.02 \\
\hline 0.16 & 0.15 & 0.11 & 0.10 & 0.10 & 0.10 & 0.09 & 0.08 & 0.09 \\
\hline 0.24 & 0.24 & 0.39 & 0.37 & 0.38 & 0.40 & 0.44 & 0.43 & 0.44 \\
\hline 0.01 & 0.01 & 0.03 & 0.01 & 0.01 & 0.01 & 0.02 & 0.01 & 0.01 \\
\hline 0.25 & 0.19 & 0.12 & 0.15 & 0.10 & 0.10 & 0.09 & 0.10 & 0.11 \\
\hline 0.24 & 0.20 & 0.14 & 0.31 & 0.28 & 0.31 & 0.31 & 0.30 & 0.30 \\
\hline 0.01 & 0.01 & 0.01 & 0.01 & 0.01 & 0.01 & 0.01 & 0.01 & 0.01 \\
\hline- & - & 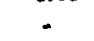 &. & - & - & - & - & 0.01 \\
\hline 8.82 & 8.73 & 8.83 & 8.76 & 8.69 & 8.76 & 8.85 & 8.82 & 8.69 \\
\hline 16.00 & 16.00 & 16.00 & 1600 & 1600 & 16.00 & 16.00 & 16.00 & 16.00 \\
\hline
\end{tabular}

Anslyzed but not detected: Co 


\begin{tabular}{|c|c|c|c|c|c|c|c|c|c|}
\hline $\begin{array}{l}\mathrm{SiO}_{2} \\
\mathrm{TiO}_{2} \\
\mathrm{MnO}_{2}\end{array}$ & $\begin{array}{r}1.06 \\
1.48 \\
65.47\end{array}$ & $\begin{array}{r}1.02 \\
1.56 \\
68.50\end{array}$ & $\begin{array}{r}1.12 \\
1.32 \\
65.93\end{array}$ & $\begin{array}{r}1.02 \\
1.78 \\
68.73\end{array}$ & $\begin{array}{r}1.11 \\
1.76 \\
68.14\end{array}$ & $\begin{array}{r}1.14 \\
1.48 \\
66.35\end{array}$ & $\begin{array}{r}0.97 \\
1.75 \\
65.87\end{array}$ & $\begin{array}{r}1.19 \\
1.64 \\
68.53\end{array}$ & $\begin{array}{r}1.10 \\
1.75 \\
67.77\end{array}$ \\
\hline $\mathrm{CeO}_{2}$ & - & - & - & - & $\mathbf{n} / \mathbf{a}$ & - & - & - & 0.37 \\
\hline $\mathrm{Al}_{2} \mathrm{O}_{3}$ & 0.49 & 0.47 & 0.47 & 0.55 & 0.65 & 0.56 & 0.55 & 0.52 & 0.64 \\
\hline $\mathrm{Fe}_{2} \mathrm{O}_{3}$ & 5.29 & 5.08 & 5.43 & 5.22 & 5.16 & 5.06 & 5.46 & 4.94 & 5.41 \\
\hline $\mathrm{MgO}$ & 0.30 & 0.10 & 0.23 & 0.26 & 0.07 & 0.27 & 0.06 & 0.21 & 0.11 \\
\hline $\mathrm{CaO}$ & 0.81 & 0.70 & 0.85 & 0.79 & 0.82 & 0.70 & 0.64 & 0.78 & 0.71 \\
\hline $\mathrm{ZnO}$ & - & 0.26 & 0.38 & 0.37 & 0.20 & 0.37 & - & $\therefore$ & 0.21 \\
\hline $\mathrm{SrO}$ & 1.19 & 1.12 & 1.41 & 1.27 & 0.96 & 1.17 & 1.10 & 1.35 & 0.99 \\
\hline $\mathrm{BaO}$ & 6.69 & 6.96 & 7.00 & 7.12 & 7.21 & 7.30 & 7.37 & 7.80 & 8.11 \\
\hline $\mathrm{PbO}$ & n/a & $\mathbf{n} / \mathbf{a}$ & $\mathbf{n} / \mathbf{a}$ & $\mathrm{n} / \mathrm{a}$ & 0.16 & $\mathbf{n} / \mathbf{a}$ & $\mathbf{n} / \mathbf{a}$ & $\mathbf{n} / \mathbf{a}$ & - \\
\hline $\mathrm{Na}_{2} \mathrm{O}$ & 0.72 & 0.74 & 0.89 & 0.72 & 0.70 & 0.68 & 0.65 & 0.65 & 0.69 \\
\hline $\mathrm{K}_{2} \mathbf{O}$ & 1.61 & 1.61 & 1.44 & 1.76 & 2.06 & 1.66 & 1.52 & 1.56 & 1.54 \\
\hline $\mathrm{La}_{2}^{2} \mathrm{O}_{3}$ & $\mathbf{n} / \mathbf{a}$ & $\mathbf{n} / \mathbf{a}$ & $\mathbf{n} / \mathbf{a}$ & $\mathbf{n} / \mathbf{a}$ & 0.19 & $\mathbf{n} / \mathbf{a}$ & n/a & $\mathbf{n} / \mathbf{a}$ & 0.14 \\
\hline Total & 85.11 & 88.12 & 86.47 & 89.59 & 89.19 & 86.74 & 85.94 & 89.17 & 89.54 \\
\hline $\mathrm{Si}^{+4}$ & 0.16 & 0.15 & 0.16 & 0.14 & 0.16 & 0.17 & 0.14 & 0.17 & 0.16 \\
\hline $\mathrm{Ti}^{+4}$ & 0.16 & 0.17 & 0.15 & 0.19 & 0.19 & 0.16 & 0.19 & 0.18 & 0.19 \\
\hline $\mathrm{Mn}^{+4}$ & 6.70 & 6.77 & 6.68 & 6.70 & 6.69 & 6.69 & 6.70 & 6.73 & 6.66 \\
\hline $\mathrm{Ce}^{+4}$ & - & - & - & - & $\mathrm{n} / \mathrm{a}$ & - & - & - & 0.02 \\
\hline $\mathrm{Al}^{+3}$ & 0.09 & 0.08 & 0.08 & 0.09 & 0.11 & 0.10 & 0.10 & 0.09 & 0.11 \\
\hline $\mathrm{Fe}^{+3}$ & 0.59 & 0.55 & 0.60 & 0.55 & 0.55 & 0.56 & 0.61 & 0.53 & 0.58 \\
\hline $\mathrm{Mg}^{+2}$ & 0.07 & 0.02 & 0.05 & 0.05 & 0.01 & 0.06 & 0.01 & 0.04 & 0.02 \\
\hline $\mathrm{Ca}^{+2}$ & 0.13 & 0.11 & 0.13 & 0.12 & 0.12 & 0.11 & 0.10 & 0.12 & 0.11 \\
\hline $\mathrm{Zn}^{+2}$ & - & 0.03 & 0.04 & 0.04 & 0.02 & 0.04 & - & - & 0.02 \\
\hline $\mathrm{Sr}^{+2}$ & 0.10 & 0.09 & 0.12 & 0.10 & 0.08 & 0.10 & 0.09 & 0.11 & 0.08 \\
\hline $\mathrm{Ba}^{+2}$ & 0.39 & 0.39 & 0.40 & 0.39 & 0.40 & 0.42 & 0.43 & 0.43 & 0.45 \\
\hline $\mathrm{Pb}^{+2}$ & $\mathbf{n} / \mathbf{a}$ & $\mathbf{n} / \mathbf{a}$ & $\mathrm{n} / \mathrm{a}$ & $\mathbf{n} / \mathbf{a}$ & 0.01 & $\mathbf{n} / \mathbf{a}$ & $\mathrm{n} / \mathrm{a}$ & $\mathrm{n} / \mathbf{a}$ & - \\
\hline $\mathrm{Na}^{+1}$ & 0.21 & 0.21 & 0.25 & 0.20 & 0.19 & 0.19 & 0.19 & 0.18 & 0.19 \\
\hline$K^{+1}$ & 0.30 & 0.29 & 0.27 & 0.32 & 0.37 & 0.31 & 0.29 & 0.28 & 0.28 \\
\hline $\mathrm{La}^{+3}$ & $\mathbf{n} / \mathbf{a}$ & $\mathrm{n} / \mathbf{a}$ & $\mathrm{n} / \mathrm{a}$ & $\mathrm{n} / \mathrm{a}$ & 0.01 & $\mathrm{n} / \mathbf{a}$ & $\mathrm{n} / \mathbf{a}$ & $\mathrm{n} / \mathbf{a}$ & 0.01 \\
\hline Total & 8.89 & 8.85 & 8.93 & 8.90 & 8.92 & 8.90 & 8.85 & 8.85 & 8.87 \\
\hline & 16.00 & 16.00 & 16.00 & 16.00 & 16.00 & 16.00 & 16.00 & 16.00 & 16.00 \\
\hline
\end{tabular}

Aralyzed but not detected: $\mathrm{Cl}, \mathrm{Y}, \mathrm{Ni}, \mathrm{P}$ 
MANGANESE OXIDES FROM 2947 FT

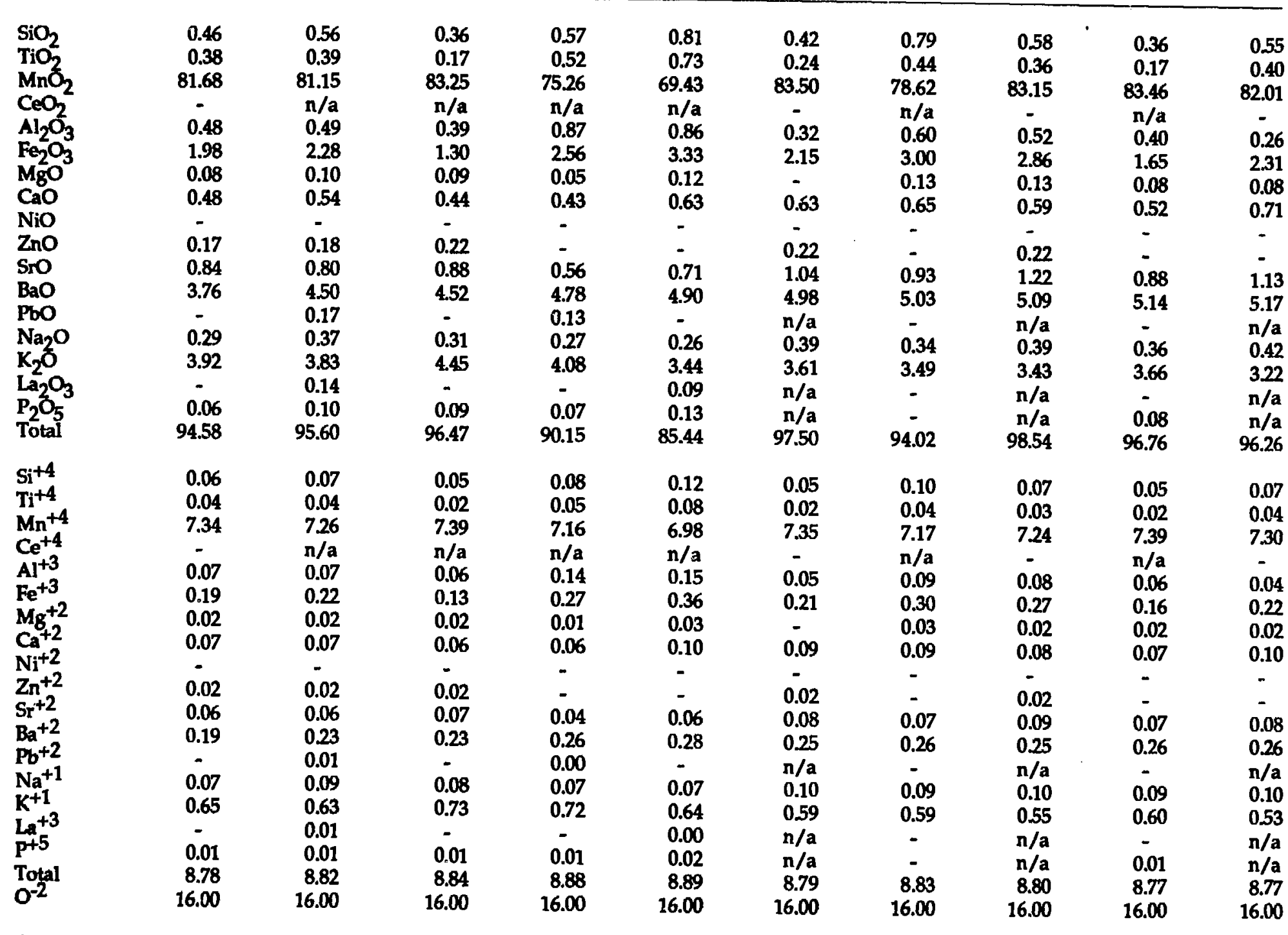

W Aralyzed but not detected: $\mathrm{Cl}, \mathrm{Y}$ 


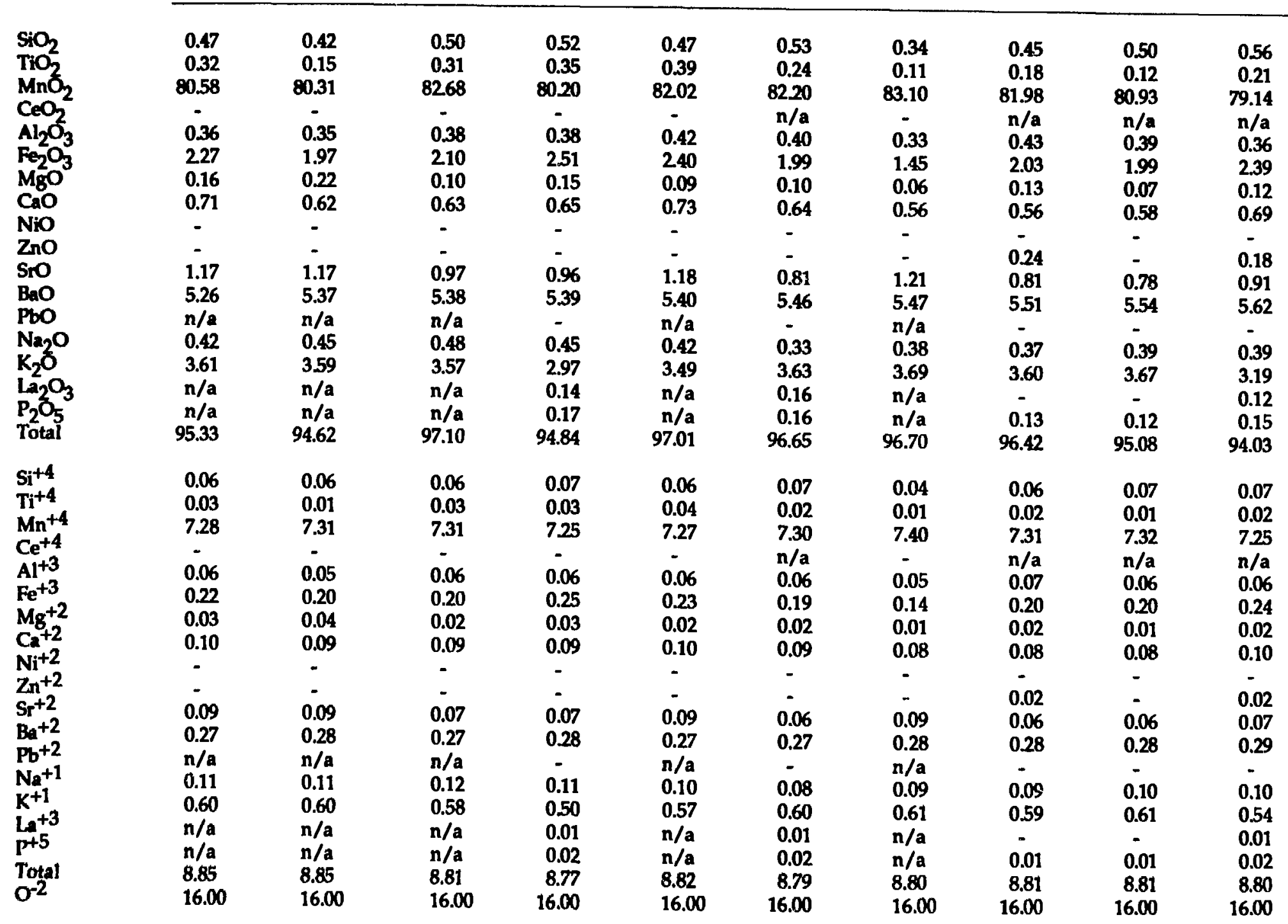

Aralyzed but not detected: $\mathbf{C}, \mathbf{Y}$ 
MANGANESE OXIDES FROM 2947 FT (cont)

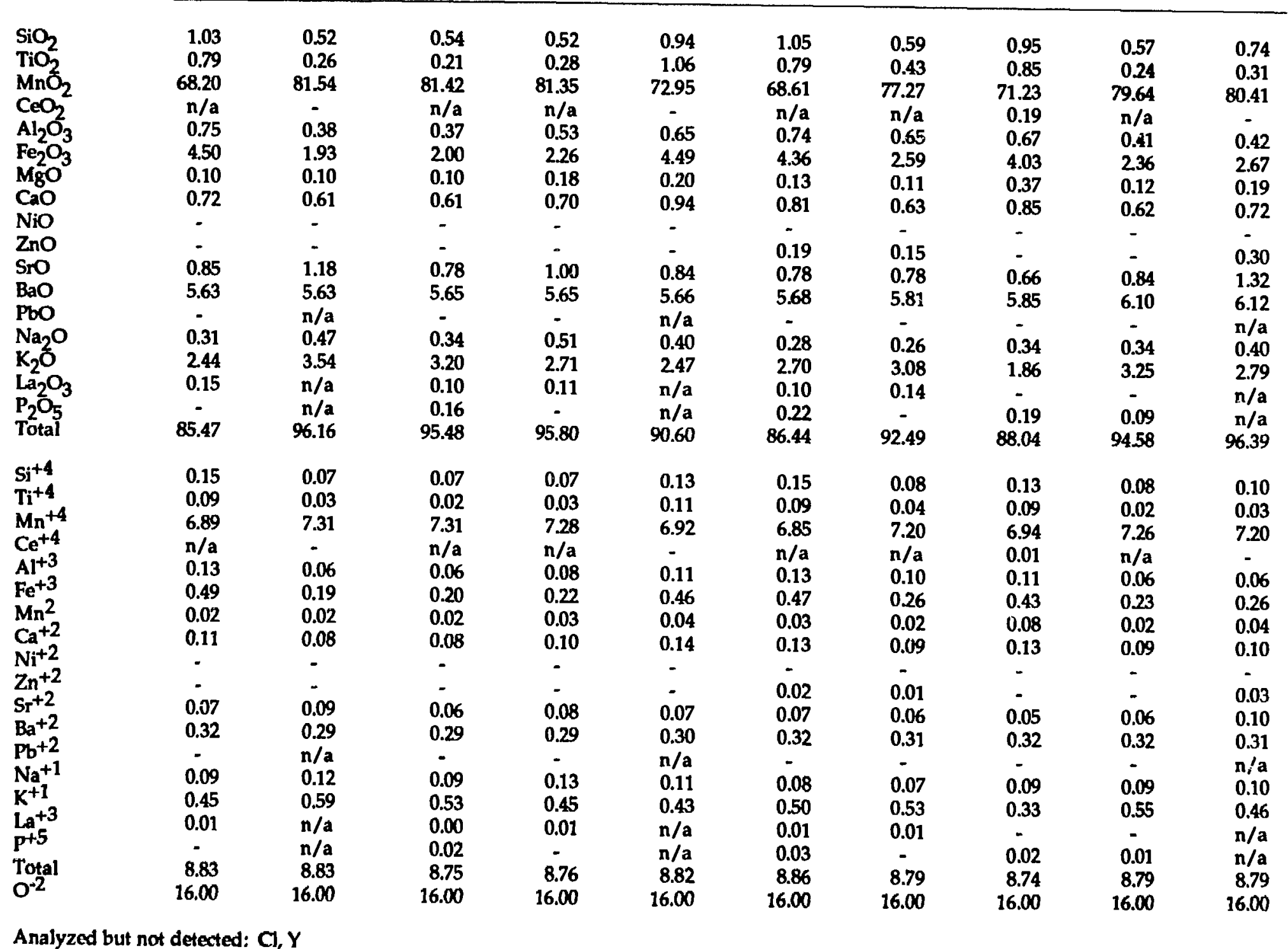




\begin{tabular}{|c|c|c|c|c|c|c|c|c|}
\hline $\begin{array}{l}\mathrm{SiO}_{2} \\
\mathrm{TO}_{2} \\
\mathrm{MnO}_{3}\end{array}$ & $\begin{array}{r}0.53 \\
0.27 \\
76.34\end{array}$ & $\begin{array}{r}0.51 \\
0.34 \\
79.04\end{array}$ & $\begin{array}{r}0.97 \\
0.83 \\
71.99\end{array}$ & $\begin{array}{r}0.59 \\
0.22 \\
79.34\end{array}$ & $\begin{array}{r}0.89 \\
0.29 \\
75.62\end{array}$ & $\begin{array}{r}0.53 \\
0.32 \\
77.00\end{array}$ & $\begin{array}{r}0.55 \\
0.48 \\
77.06\end{array}$ & $\begin{array}{r}0.56 \\
0.64 \\
77.73\end{array}$ \\
\hline $\mathrm{CeO}_{2}{ }^{2}$ & 0.27 & - & $\mathbf{n} / \mathbf{a}$ & $\mathrm{n} / \mathrm{a}$ & $\mathrm{n} / \mathrm{a}$ & 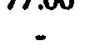 & - & $\begin{array}{c}17.13 \\
-\end{array}$ \\
\hline $\mathrm{Al}_{2} \mathrm{O}_{3}$ & 0.44 & 0.37 & 0.47 & 0.43 & 0.63 & 0.72 & 0.60 & 0.54 \\
\hline $\mathrm{Fe}_{2} \mathrm{O}_{3}$ & 2.27 & 2.43 & 5.77 & 2.26 & 3.61 & 1.64 & 1.94 & 2.44 \\
\hline $\mathrm{MBO}$ & 0.13 & 0.10 & 0.58 & 0.13 & 0.26 & 0.15 & 0.21 & 0.25 \\
\hline $\mathrm{CaO}$ & 0.63 & 0.78 & 1.40 & 0.68 & 1.34 & 1.09 & 1.16 & 1.26 \\
\hline NiO & 0.20 & - & - & - & - & - & - & 0.12 \\
\hline Zno & - & - & 0.20 & 0.28 & 0.21 & - & - & 0.41 \\
\hline Sro & 0.92 & 1.27 & 1.08 & 0.92 & 1.14 & 1.19 & 1.21 & 1.61 \\
\hline $\mathrm{BaO}$ & 6.20 & 6.21 & 6.35 & 6.50 & 6.58 & 8.32 & 9.60 & 9.75 \\
\hline PbO & 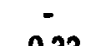 & $\mathrm{n} / \mathrm{a}$ & - & - & - & $\mathrm{n} / \mathrm{a}$ & $\mathrm{n} / \mathrm{a}$ & $n / a$ \\
\hline $\mathrm{Na}_{2} \mathrm{O}$ & 0.33 & 0.42 & 0.46 & 0.38 & 0.79 & 0.47 & 0.58 & 0.64 \\
\hline $\mathrm{K}_{2} \mathrm{O}$ & 1.89 & 3.02 & 1.23 & 2.77 & 0.49 & 0.48 & 0.47 & 0.49 \\
\hline $\mathrm{La}_{2} \mathrm{O}_{3}$ & 0.15 & $\mathbf{n} / \mathbf{a}$ & 0.11 & 0.09 & 0.22 & $n / a$ & $n / a$ & $n / a$ \\
\hline $\mathrm{P}_{2} \mathrm{O}_{5}$ & 0.14 & n/a & 0.09 & 0.20 & - & $\mathrm{n} / \mathrm{a}$ & $\mathbf{n} / \mathbf{a}$ & $\mathrm{n} / \mathrm{a}$ \\
\hline Total & 90.71 & 94.49 & 91.53 & 94.79 & 92.07 & 91.91 & 93.86 & 96.44 \\
\hline $\begin{array}{l}\mathrm{si}^{+4} \\
\mathrm{r}+4\end{array}$ & 0.07 & 0.07 & 0.13 & 0.08 & 0.12 & 0.07 & 0.07 & 0.07 \\
\hline $\mathrm{Ti}^{+4}$ & 0.03 & 0.03 & 0.09 & 0.02 & 0.03 & 0.03 & 0.05 & 0.06 \\
\hline $\mathrm{Mn}^{+4}$ & 7.25 & 7.24 & 6.80 & 7.23 & 7.07 & 7.26 & 7.19 & 7.10 \\
\hline $\mathrm{Ce}^{+2}$ & 0.01 & $\therefore$ & $\mathrm{n} / \mathrm{a}$ & $\mathbf{n} / \mathbf{a}$ & $\mathrm{n} / \mathrm{a}$ & - & - & - \\
\hline$A \mid+3$ & 0.07 & 0.06 & 0.08 & 0.07 & 0.10 & 0.12 & 0.10 & 0.08 \\
\hline $\mathrm{Fe}^{+3}$ & 0.23 & 0.24 & 0.59 & 0.22 & 0.37 & 0.17 & 0.20 & 0.24 \\
\hline $\mathrm{Mg}_{+2}^{+2}$ & 0.03 & 0.02 & 0.12 & 0.03 & 0.05 & 0.03 & 0.04 & 0.05 \\
\hline $\begin{array}{cc}C+2 \\
\text { and }\end{array}$ & 0.09 & 0.11 & 0.20 & 0.10 & 0.19 & 0.16 & 0.17 & 0.18 \\
\hline $\begin{array}{l}\mathrm{Ni}^{2} \\
\mathrm{Zn}+2\end{array}$ & 0.02 & - & - & - & - & - & - & 0.01 \\
\hline $\begin{array}{ll}2 \pi \\
c+2\end{array}$ & - & $\therefore$ & 0.02 & 0.03 & 0.02 & - & - & 0.04 \\
\hline $\begin{array}{l}5+2 \\
0+2\end{array}$ & 0.07 & 0.10 & 0.09 & 0.07 & 0.09 & 0.09 & 0.09 & 0.12 \\
\hline $\begin{array}{l}\mathrm{Ba}+2 \\
\mathrm{~Pa}+2\end{array}$ & 0.33 & 0.32 & 0.34 & 0.34 & 0.35 & 0.45 & 0.51 & 0.51 \\
\hline $\begin{array}{l}P^{+2} \\
N_{-}+1\end{array}$ & 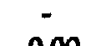 & n/a & $\therefore$ & - & - & $\mathrm{n} / \mathrm{a}$ & $\mathrm{n} / \mathrm{a}$ & $n / a$ \\
\hline $\begin{array}{l}\mathrm{Na}^{\mathrm{T}} \\
\mathrm{K}+1\end{array}$ & 0.09 & 0.11 & 0.12 & 0.10 & 0.21 & 0.12 & 0.15 & 0.16 \\
\hline $\begin{array}{l}K \\
1\end{array}$ & 0.33 & 0.51 & 0.21 & 0.47 & 0.08 & 0.08 & 0.08 & 0.08 \\
\hline & 0.01 & $n / a$ & 0.01 & 0.00 & 0.01 & $n / a$ & n/a & $n / a$ \\
\hline & 0.02 & $\mathbf{n} / \mathbf{a}$ & 0.01 & 0.02 & - & $n / a$ & $n / a$ & $n / a$ \\
\hline $0^{-2}$ & 8.66 & 8.81 & 8.80 & 8.77 & 8.69 & 8.59 & 8.65 & 8.72 \\
\hline & 16.00 & 16.00 & 16.00 & 16.00 & 16.00 & 16.00 & 16.00 & 16.00 \\
\hline
\end{tabular}

Analyzed but not detected: $\mathrm{Cl}, \mathrm{Y}$ 
MANGANESE OXIDES FROM 2954-2955 FT

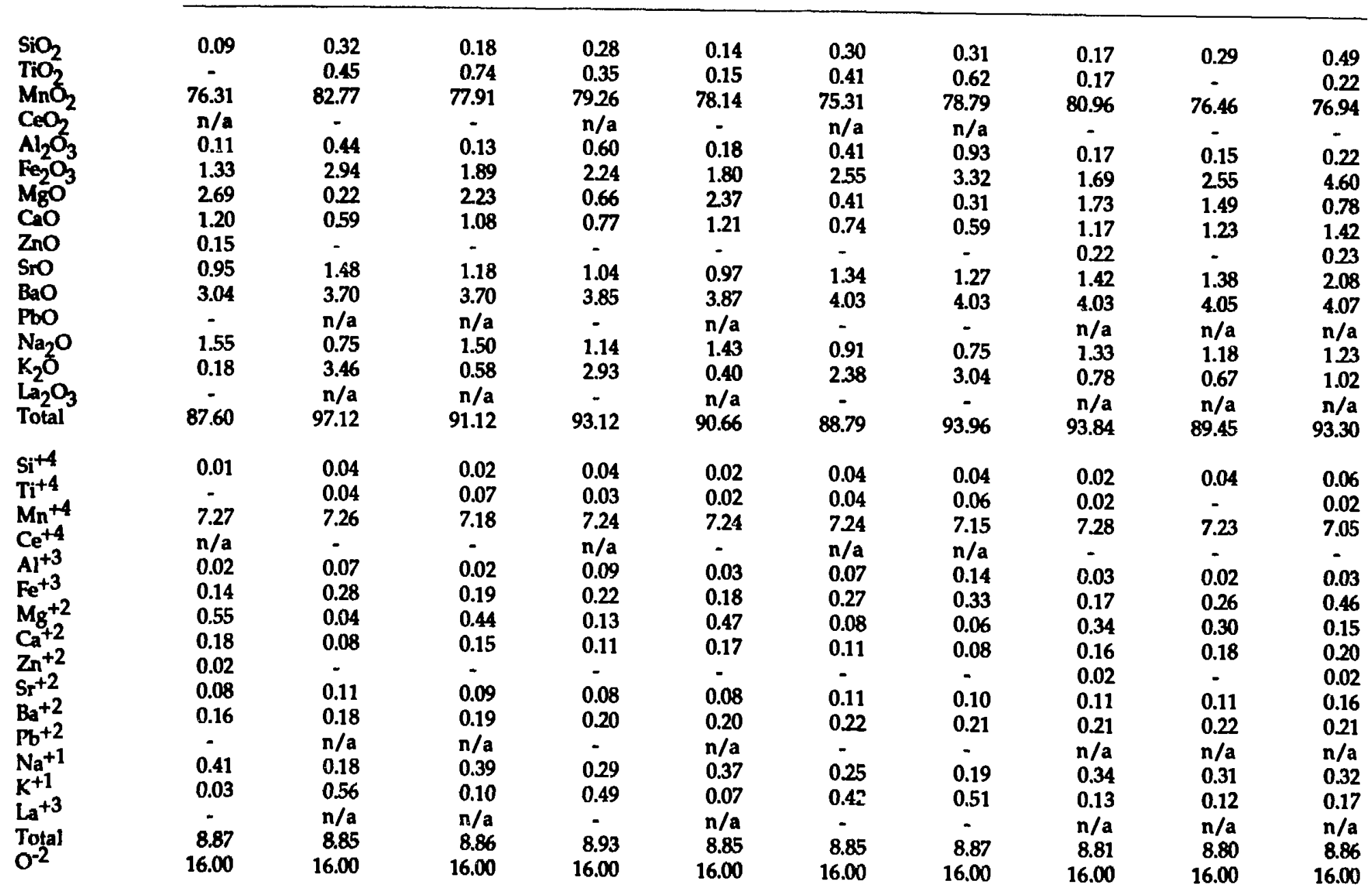

Analyzed but not detected: $\mathrm{P}, \mathrm{Cl}, \mathrm{Co}, \mathrm{Cu}, \mathrm{Y}, \mathrm{Ni}$ 
MANGANESE OXIDES FROM 2954-2955 FT (cont)

\begin{tabular}{|c|c|c|c|c|c|c|c|c|c|c|}
\hline $\begin{array}{l}\mathrm{SiO}_{2} \\
\mathrm{TiO}_{2} \\
\mathrm{MnO}_{2}\end{array}$ & $\begin{array}{r}0.34 \\
0.51 \\
77.96\end{array}$ & $\begin{array}{r}0.20 \\
0.21 \\
78.69\end{array}$ & $\begin{array}{r}0.30 \\
0.37 \\
73.34\end{array}$ & $\begin{array}{r}0.39 \\
0.67 \\
81.03\end{array}$ & $\begin{array}{r}0.24 \\
0.20 \\
78.89\end{array}$ & $\begin{array}{r}0.84 \\
0.45 \\
70.26\end{array}$ & $\begin{array}{r}0.62 \\
0.62 \\
71.11\end{array}$ & $\begin{array}{r}0.33 \\
0.33 \\
78.79\end{array}$ & $\begin{array}{r}0.28 \\
0.18 \\
79.55\end{array}$ & $\begin{array}{r}0.44 \\
0.49 \\
74.36\end{array}$ \\
\hline $\mathrm{CeO}_{2}{ }^{2}$ & $\mathbf{n} / \mathbf{a}$ & - & $\mathbf{n} / \mathbf{a}$ & - & - & - & - & - & - & $\begin{array}{l}14.00 \\
n / a\end{array}$ \\
\hline $\mathrm{Al}_{2} \mathrm{O}_{3}$ & 0.55 & 0.14 & 0.41 & 0.62 & 0.18 & 0.52 & 0.35 & 0.39 & 0.22 & 0.49 \\
\hline $\mathrm{Fe}_{2} \mathrm{O}_{3}$ & 2.63 & 1.96 & 2.70 & 3.58 & 2.38 & 3.54 & 4.21 & 2.69 & 1.99 & 2.94 \\
\hline $\mathrm{MgO}$ & 0.33 & 2.18 & 0.59 & 0.20 & 1.29 & 0.22 & 0.45 & 0.82 & 1.30 & 0.76 \\
\hline $\mathrm{CaO}$ & 0.67 & 1.20 & 0.76 & 0.35 & 1.13 & 0.85 & 0.95 & 0.90 & 1.18 & 1.01 \\
\hline $\mathrm{ZnO}$ & - & $\therefore$ & - & - & 0.25 & 0.16 & 0.31 & 0.26 & - & 0.19 \\
\hline Sro & 1.09 & 1.15 & 1.11 & 1.03 & 1.08 & 1.33 & 1.67 & 1.20 & 1.23 & 0.91 \\
\hline $\mathrm{BaO}$ & 4.21 & 4.22 & 4.27 & 4.28 & 4.43 & 4.51 & 4.55 & 4.59 & 4.61 & 4.63 \\
\hline PbO & $\therefore$ & $\mathrm{n} / \mathrm{a}$ & - & $\mathrm{n} / \mathrm{a}$ & $\mathrm{n} / \mathrm{a}$ & $n / a$ & $\mathrm{n} / \mathrm{a}$ & $n / a$ & $n / a$ & - \\
\hline $\mathrm{Na}_{2} \mathrm{O}$ & 0.64 & 1.51 & 0.89 & 0.53 & 0.97 & 0.58 & 0.75 & 0.85 & 1.05 & 0.78 \\
\hline $\mathrm{K}_{2} \mathrm{O}$ & 2.82 & 0.40 & 2.35 & 3.75 & 1.28 & 2.41 & 1.67 & 2.09 & 1.37 & 2.05 \\
\hline $\begin{array}{l}\mathrm{La}_{2} \mathrm{O}_{3} \\
\text { Total }\end{array}$ & $\overline{91.75}$ & $\begin{array}{r}n / a \\
91.86\end{array}$ & 8700 & $\begin{array}{r}n / a \\
96,43\end{array}$ & $\begin{array}{r}n / a \\
92.32\end{array}$ & $\begin{array}{r}n / a \\
8567\end{array}$ & $\begin{array}{r}n / a \\
8726\end{array}$ & n/a & $n / a$ & - \\
\hline $\mathrm{si}+4$ & & & & & & & & & & \\
\hline $\mathrm{Ti}+4$ & 0.05 & 0.03 & 0.04 & 0.05 & 0.03 & 0.12 & 0.09 & 0.04 & 0.04 & 0.06 \\
\hline $\mathrm{Mn}^{+4}$ & 0.05 & 0.02 & 0.04 & 0.06 & 0.02 & 0.05 & 0.07 & 0.03 & 0.02 & 0.05 \\
\hline $\mathrm{Ce}^{+4}$ & 7.24 & 7.22 & 7.20 & 7.18 & 7.25 & 7.04 & 7.00 & 7.21 & 7.27 & 7.13 \\
\hline $\mathrm{Al}^{+3}$ & $\begin{array}{l}n / a \\
n 09\end{array}$ & - & $\mathrm{n} / \mathrm{a}$ & - & - & - & - & - & - & $n / a$ \\
\hline $\mathrm{Fe}^{+3}$ & $\begin{array}{l}0.09 \\
027\end{array}$ & 0.02 & 0.07 & 0.09 & 0.03 & 0.09 & 0.06 & 0.06 & 0.03 & 0.08 \\
\hline $\mathrm{Mg}^{+2}$ & $\begin{array}{l}0.27 \\
0.07\end{array}$ & 0.20 & 0.29 & 0.35 & 0.24 & 0.39 & 0.45 & 0.27 & 0.20 & 0.31 \\
\hline $\mathrm{Ca}^{+2}$ & $\begin{array}{l}0.07 \\
0.10\end{array}$ & 0.43 & 0.12 & 0.04 & 0.26 & 0.05 & 0.10 & 0.16 & 0.26 & 0.16 \\
\hline $\mathrm{Zn}+2$ & $\begin{array}{c}0.10 \\
-\end{array}$ & 0.17 & 0.12 & 0.05 & 0.16 & 0.13 & 0.15 & 0.13 & 0.17 & 0.15 \\
\hline $\mathrm{Sr}^{+}+2$ & 0.08 & 0 & $=$ & - & 0.02 & 0.02 & 0.03 & 0.03 & - & 0.02 \\
\hline $\mathrm{Ba}+2$ & $\begin{array}{l}0.00 \\
0.22\end{array}$ & $\begin{array}{l}0.09 \\
0.22\end{array}$ & 0.09 & 0.08 & 0.08 & 0.11 & 0.14 & 0.09 & 0.09 & 0.07 \\
\hline $\mathrm{Pb}^{+2}$ & - & $\mathrm{n} / \mathrm{a}$ & 0.24 & 0.22 & 0.23 & 0.26 & 0.25 & 0.24 & 0.24 & 0.25 \\
\hline $\mathrm{Na}^{+1}$ & 0.17 & 0.39 & - & $n / a$ & $\mathrm{n} / \mathrm{a}$ & $n / a$ & $\mathrm{n} / \mathrm{a}$ & n/a & $n / a$ & - \\
\hline $\mathrm{K}^{+1}$ & 0.48 & 0.07 & 0.25 & 0.13 & 0.25 & 0.16 & 0.21 & 0.22 & 0.27 & 0.21 \\
\hline $\mathrm{La}^{\mathrm{a}}+3$ & 0.40 & $\mathrm{n} / \mathrm{a}$ & 0.43 & 0.61 & 0.22 & 0.45 & 0.30 & 0.35 & 0.23 & 0.36 \\
\hline Total & 8.81 & $\begin{array}{l}n / \mathrm{a} \\
8.85\end{array}$ & 8.88 & n/a & $\mathrm{n} / \mathrm{a}$ & $\mathrm{n} / \mathrm{a}$ & $n / a$ & $n / a$ & $\mathbf{n} / \mathbf{a}$ & - \\
\hline & 16.00 & 16.00 & $\begin{array}{r}0.00 \\
16.00\end{array}$ & $\begin{array}{r}8.86 \\
16.00\end{array}$ & $\begin{array}{r}8.80 \\
16.00\end{array}$ & $\begin{array}{r}8.86 \\
16.00\end{array}$ & $\begin{array}{r}8.84 \\
16.00\end{array}$ & $\begin{array}{r}8.83 \\
16.00\end{array}$ & $\begin{array}{r}8.81 \\
16.00\end{array}$ & $\begin{array}{r}8.85 \\
1600\end{array}$ \\
\hline
\end{tabular}

Analyzed but not detected: $\mathrm{P}, \mathrm{Cl}, \mathrm{Co}, \mathrm{Cu}, \mathrm{Y}, \mathrm{Ni}$ 
MANGANESE OXIDES FROM 2954-2955 FT (cont)

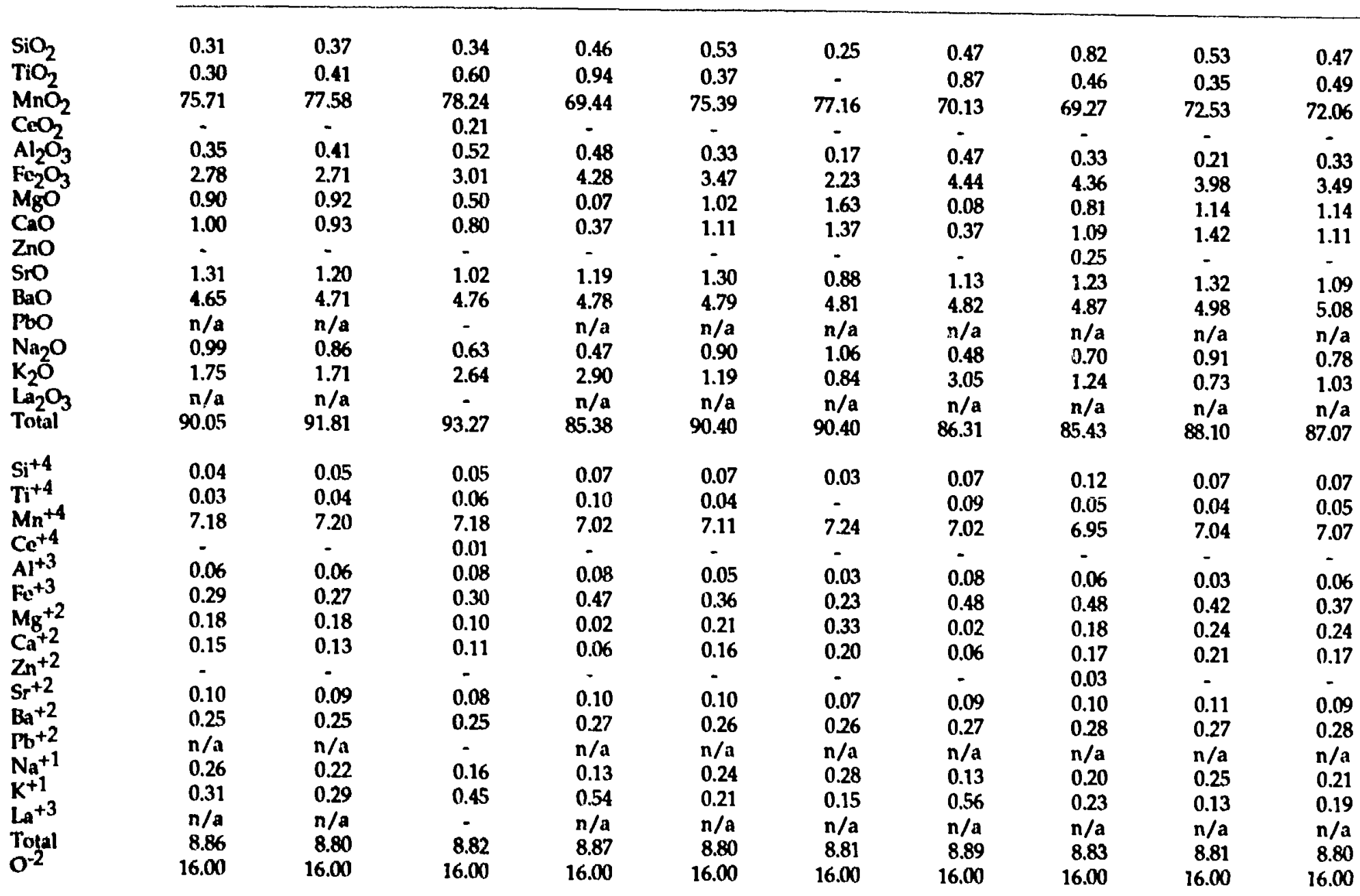


MANGANESE OXIDES FROM 2954-2955 FT (cont)

\begin{tabular}{|c|c|c|c|c|c|c|}
\hline $\mathrm{SiO}_{3}$ & 0.23 & 0.81 & 0.23 & 0.35 & 0.33 & 0.77 \\
\hline TiO & 0.19 & 0.39 & 0.14 & 0.26 & 0.36 & 0.48 \\
\hline $\mathrm{MnO}_{2}$ & 75.89 & 72.92 & 79.80 & 74.65 & 75.45 & 73.82 \\
\hline $\mathrm{CeO}_{2}{ }^{2}$ & - & - & - & $\mathrm{n} / \mathrm{a}$ & - & - \\
\hline $\mathrm{Al}_{2} \mathrm{O}_{3}$ & 0.26 & 0.34 & 0.18 & 0.18 & 0.34 & 0.40 \\
\hline $\mathrm{Fe}_{2} \mathrm{O}_{3}$ & 2.24 & 4.14 & 2.43 & 3.03 & 3.22 & 5.17 \\
\hline $\mathrm{MgO}^{\circ}$ & 1.52 & 0.72 & 1.18 & 1.50 & 1.58 & 0.88 \\
\hline $\mathrm{CaO}$ & 1.34 & 1.22 & 1.22 & 1.28 & 1.44 & 1.54 \\
\hline $\mathrm{ZnO}$ & - & 0.26 & 0.34 & 0.15 & - & - \\
\hline SrO & 0.78 & 1.60 & 1.44 & 0.87 & 0.62 & 1.06 \\
\hline $\mathrm{BaO}$ & 5.08 & 5.19 & 5.23 & 5.35 & 6.10 & 6.21 \\
\hline $\mathrm{PbO}$ & 0.11 & $\mathrm{n} / \mathrm{a}$ & $\mathrm{n} / \mathrm{a}$ & - & - & 0.14 \\
\hline $\mathrm{Na}_{2} \mathrm{O}$ & 0.97 & 0.69 & 0.86 & 1.13 & 0.94 & 0.84 \\
\hline $\mathrm{K}_{2} \mathrm{O}$ & 0.70 & 1.32 & 1.06 & 0.62 & 0.41 & 0.81 \\
\hline $\mathrm{La}_{2} \mathrm{O}_{3}$ & - & $\mathbf{n} / \mathbf{a}$ & n/a & - & - & 0.11 \\
\hline Total & 89.31 & 89.60 & 94.11 & 89.37 & 90.79 & 92.23 \\
\hline $\mathrm{Si}^{+4}$ & 0.03 & 0.11 & 0.03 & 0.05 & 0.04 & 0.10 \\
\hline $\mathrm{Ti}^{+4}$ & 0.02 & 0.04 & 0.01 & 0.03 & 0.04 & 0.05 \\
\hline $\mathrm{Mn}^{+4}$ & 7.22 & 6.99 & 7.25 & 7.13 & 7.10 & 6.90 \\
\hline $\mathrm{Ce}^{+4}$ & - & - & - & $n / a$ & - & - \\
\hline $\mathrm{Al}^{+3}$ & 0.04 & 0.06 & 0.03 & 0.03 & 0.05 & 0.06 \\
\hline $\mathrm{Fe}^{+3}$ & 0.23 & 0.43 & 0.24 & 0.31 & 0.33 & 0.53 \\
\hline $\mathrm{Mg}^{+2}$ & 0.31 & 0.15 & 0.23 & 0.31 & 0.32 & 0.18 \\
\hline $\mathrm{Ca}^{+2}$ & 0.20 & 0.18 & 0.17 & 0.19 & 0.21 & 0.22 \\
\hline $\mathrm{Zn}{ }^{+2}$ & - & 0.03 & 0.03 & 0.02 & - & - \\
\hline $5 r+2$ & 0.06 & 0.13 & 0.11 & 0.07 & 0.05 & 0.08 \\
\hline $\mathrm{Ba}^{+2}$ & 0.27 & 0.28 & 0.27 & 0.29 & 0.33 & 0.33 \\
\hline $\mathrm{Pb}^{+2}$ & 0.00 & $\mathrm{n} / \mathrm{a}$ & $\mathrm{n} / \mathrm{a}$ & - & - & 0.01 \\
\hline $\mathrm{Na}^{+1}$ & 0.26 & 0.19 & 0.22 & 0.30 & 0.25 & 0.22 \\
\hline$K^{+1}$ & 0.12 & 0.23 & 0.18 & 0.11 & 0.07 & 0.14 \\
\hline $\mathrm{La}^{+3}$ & - & $\mathrm{n} / \mathrm{a}$ & $\mathrm{n} / \mathrm{a}$ & - & - & 0.01 \\
\hline Total & 8.78 & 8.82 & 8.77 & 8.83 & 8.79 & 8.83 \\
\hline & 16.00 & 16.00 & 16.00 & 16.00 & 16.00 & 16.00 \\
\hline
\end{tabular}

Analyzed but not detected: $\mathrm{P}, \mathrm{Cl}, \mathrm{Co}, \mathrm{Cu}, \mathrm{Y}, \mathrm{Ni}$ 
MANGANESE OXIDES FROM 2967 FT

Cryptomelane

Dark (see text)

\begin{tabular}{|c|c|c|c|c|c|c|c|c|}
\hline $\mathrm{SiO}_{2}$ & 0.52 & 0.70 & 1.16 & 0.44 & 0.30 & 0.18 & 0.43 & 0.48 \\
\hline $\mathrm{TiO}_{2}$ & 1.15 & 1.10 & 1.18 & 0.41 & 0.32 & 0.21 & 0.57 & 0.50 \\
\hline $\mathrm{MnO}_{2}$ & 73.49 & 75.29 & 69.02 & 78.63 & 79.97 & 80.70 & 74.41 & 76.76 \\
\hline $\mathrm{CeO}_{2}{ }^{2}$ & - & $\mathbf{n} / \mathbf{a}$ & $\mathbf{n} / \mathbf{a}$ & 1.81 & n/a & - & 0.53 & $\mathrm{n} / \mathbf{a}$ \\
\hline $\mathrm{Al}_{2} \mathrm{O}_{3}$ & 0.67 & 0.64 & 0.81 & 0.38 & 0.38 & 0.49 & 0.46 & 0.43 \\
\hline $\mathrm{Fe}_{2} \mathrm{O}_{3}$ & 4.01 & 4.15 & 4.44 & 2.75 & 1.87 & 1.78 & 268 & 2.72 \\
\hline $\mathrm{MgO}^{2}$ & 0.07 & 0.10 & 0.06 & 0.38 & 0.47 & 0.30 & 0.24 & 0.25 \\
\hline $\mathrm{CaO}$ & 0.47 & 0.42 & 0.45 & 0.89 & 0.79 & 0.73 & 0.73 & 0.71 \\
\hline $\mathrm{ZnO}$ & - & 0.16 & - & 0.22 & - & 0.23 & 0.21 & 0.16 \\
\hline SrO & 0.91 & 0.99 & 0.93 & 1.03 & 1.19 & 1.14 & 1.13 & 1.17 \\
\hline $\mathrm{BaO}$ & 5.54 & 5.86 & 6.07 & 6.12 & 6.30 & 6.40 & 7.18 & 7.45 \\
\hline PbO & - & - & - & 0.35 & - & 0.21 & 0.26 & 0.25 \\
\hline $\mathrm{Na}_{2} \mathrm{O}$ & 0.38 & 0.44 & 0.31 & 0.68 & 0.65 & 0.56 & 0.53 & 0.54 \\
\hline $\mathrm{K}_{2} \mathrm{O}$ & 269 & 3.05 & 2.64 & 2.15 & 2.24 & 2.43 & 1.61 & 2.11 \\
\hline $\mathrm{La}_{2} \mathrm{O}_{3}$ & - & - & - & - & - & - & - & 0.13 \\
\hline Total & 89.90 & 9290 & 87.07 & 96.24 & 94.48 & 95.36 & 90.97 & 93.66 \\
\hline $\mathrm{Si}^{+4}$ & 0.07 & 0.09 & 0.17 & 0.06 & 0.04 & 0.02 & 0.06 & 0.06 \\
\hline $\mathrm{Ti}^{+4}$ & 0.12 & 0.11 & 0.13 & 0.04 & 0.03 & 0.02 & 0.06 & 0.05 \\
\hline $\mathrm{Mn}^{+4}$ & 7.04 & 7.00 & 6.85 & 7.13 & 7.30 & 7.33 & 7.15 & 7.16 \\
\hline $\mathrm{Ce}^{+4}$ & - & $\mathrm{n} / \mathrm{a}$ & $n / a$ & 0.08 & n/a & - & 0.03 & $\mathrm{n} / \mathrm{a}$ \\
\hline $\mathrm{Al}^{+3}$ & 0.11 & 0.10 & 0.14 & 0.06 & 0.06 & 0.08 & 0.08 & 0.07 \\
\hline $\mathrm{Fe}^{+3}$ & 0.42 & 0.42 & 0.48 & 0.27 & 0.19 & 0.18 & 0.28 & 0.28 \\
\hline $\mathrm{Mg}^{+2}$ & 0.01 & 0.02 & 0.01 & 0.07 & 0.09 & 0.06 & 0.05 & 0.05 \\
\hline $\mathrm{Ca}^{+2}$ & 0.07 & 0.06 & 0.07 & 0.13 & 0.11 & 0.10 & 0.11 & 0.10 \\
\hline $\mathrm{Zn}^{+2}$ & - & 0.02 & - & 0.02 & - & 0.02 & 0.02 & 0.02 \\
\hline $\mathrm{Sr}^{+2}$ & 0.07 & 0.08 & 0.08 & 0.08 & 0.09 & 0.09 & 0.09 & 0.09 \\
\hline $\mathrm{Ba}^{+2}$ & 0.30 & 0.31 & 0.34 & 0.31 & 0.33 & 0.33 & 0.39 & 0.39 \\
\hline $\mathrm{Pb}^{+2}$ & - & - & - & 0.01 & - & 0.01 & 0.01 & 0.01 \\
\hline $\mathrm{Na}^{+1}$ & 0.10 & 0.11 & 0.09 & 0.17 & 0.17 & 0.14 & 0.14 & 0.14 \\
\hline$K^{+1}$ & 0.48 & 0.52 & 0.48 & 0.36 & 0.38 & 0.41 & 0.29 & 0.36 \\
\hline $\mathrm{La}^{+3}$ & - & - & - & - & - & - & - & 0.01 \\
\hline Total & 8.79 & 8.85 & 8.83 & 8.79 & 8.78 & 8.78 & 8.75 & 8.80 \\
\hline & 16.00 & 16.00 & 16.00 & 16.00 & 16.00 & 16.00 & 16.00 & 16.00 \\
\hline
\end{tabular}

$\begin{array}{r}1.56 \\ 1.56 \\ 64.61 \\ 0.32 \\ 0.55 \\ 7.78 \\ 0.24 \\ 1.47 \\ 0.19 \\ 1.52 \\ 7.17 \\ 0.43 \\ 0.23 \\ 0.91 \\ 0.16 \\ 88.70 \\ \hline \\ 0.22 \\ 0.17 \\ 6.41 \\ 0.02 \\ 0.09 \\ 0.84 \\ 0.05 \\ 0.23 \\ 0.02 \\ 0.13 \\ 0.40 \\ 0.02 \\ 0.06 \\ 0.17 \\ 0.01 \\ 8.83 \\ 16.00 \\ \hline\end{array}$

Analyzed, but not detected: $\mathrm{Cl}, \mathrm{Y}, \mathrm{Ni}$ 
The following number is for Office of Civilian Radioactive Waste Management purposes only and shoulc not be used when ordering this document:

Accession Number: NNA.900206.0163 